\title{
Early Land-use and Landscape Development in Arisaig
}

by Stephen Carter, ${ }^{1}$ Magnar Dalland ${ }^{1}$ and Deborah Long $^{2}$

${ }^{1}$ Headland Archaeology Ltd, 13 Jane Street, Edinburgh EH6 5HE ${ }^{2}$ Plantlife Scotland, Balallan House, Allan Park, Stirling FK8 2QG with a contribution by Caroline Wickham-Jones 
Published by the Society of Antiquaries of Scotland, www.socantscot.org with Historic Scotland, www.historic-scotland.gov.uk and the Council for British Archaeology, www.britarch.ac.uk

Editor Debra Barrie

Produced by Archetype Information Technology Ltd, www.archetype-it.com

ISBN: 0903903849

ISSN: $1473-3803$

Requests for permission to reproduce material from a SAIR report should be sent to the Director of the Society of Antiquaries of Scotland, as well as to the author, illustrator, photographer or other copyright holder.

Copyright in any of the Scottish Archaeological Internet Reports series rests with the SAIR Consortium and the individual authors.

The maps are reproduced from Ordnance Survey material with the permission of Ordnance Survey on behalf of The Controller of Her Majesty's Stationery Office. (CCrown copyright 2001. Any unauthorized reproduction infringes Crown copyright and may lead to prosecution or civil proceedings. Historic Scotland Licence No GD 03032G, 2002.

The consent does not extend to copying for general distribution, advertising or promotional purposes, the creation of new collective works or resale. 


\section{Contents}

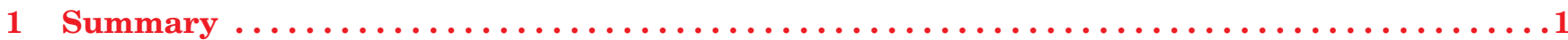

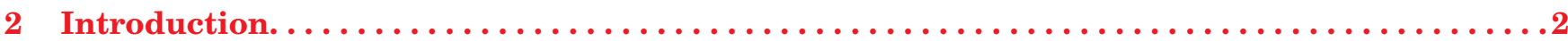

3 The Archaeology of Arisaig: Early Investigations $\ldots \ldots \ldots \ldots \ldots \ldots \ldots \ldots \ldots \ldots \ldots \ldots$

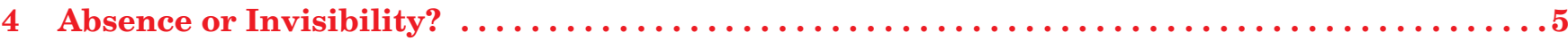

5 A Transect Across the Landscape: the Line of the A830 Improvements .............6

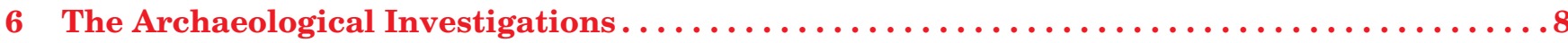

6.1 Shieling huts and circular stone features: Sites 3-6 (centred on NM 6675 9005) . . . . . . . . 8

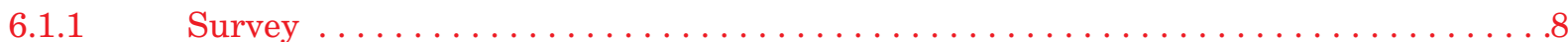

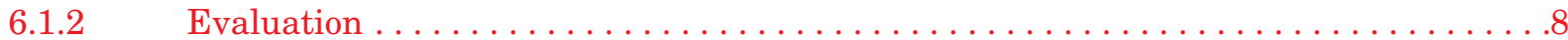

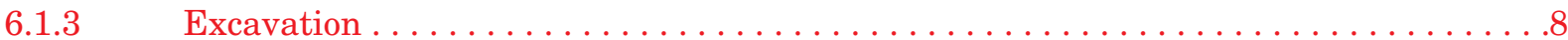

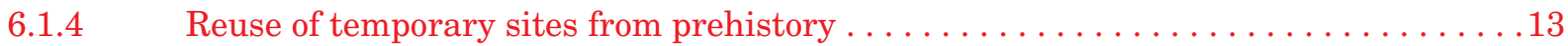

6.2 Shieling huts and cultivation rigs: Site 8 (centred on NM 659888$) \ldots \ldots \ldots \ldots \ldots \ldots \ldots \ldots$

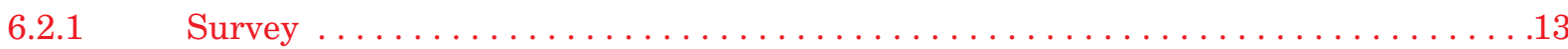

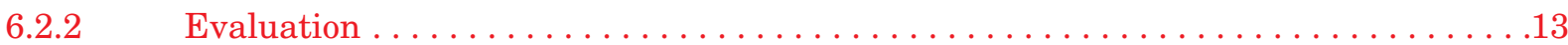

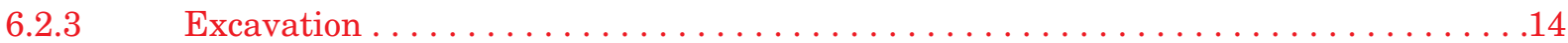

6.2.4 Lithics by $C$ Wickham-Jones...................................... 17

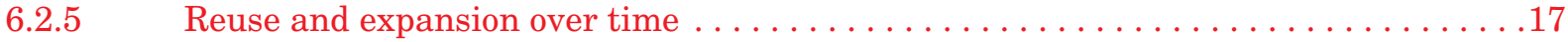

6.3 Rectangular turf structure: Site $10(\mathrm{NM} 65838835) \ldots \ldots \ldots \ldots \ldots \ldots \ldots \ldots \ldots \ldots \ldots$

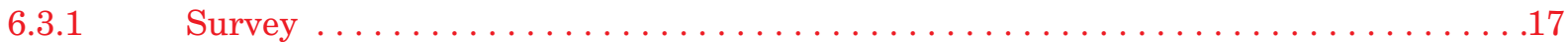

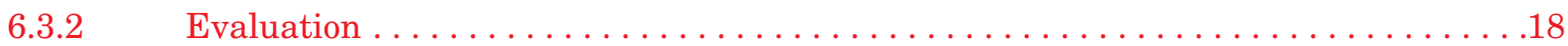

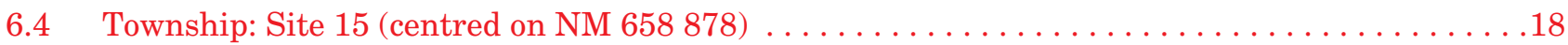

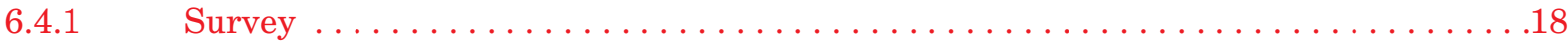

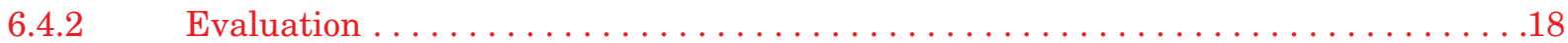

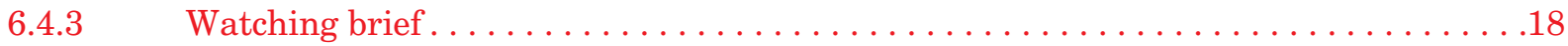

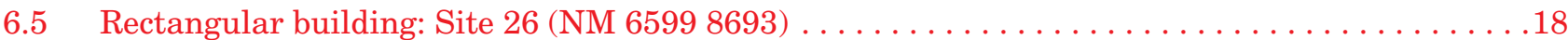

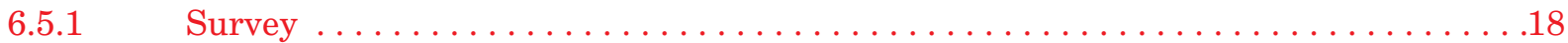

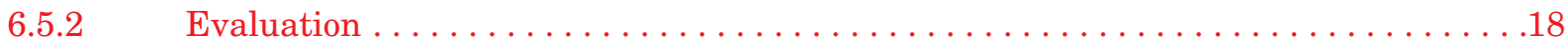

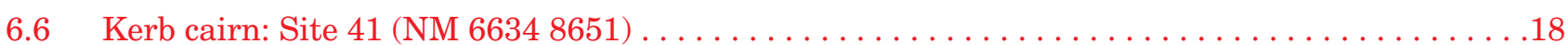

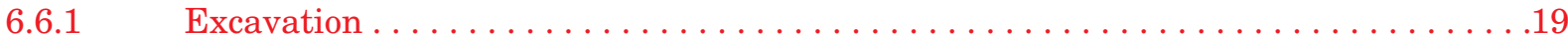

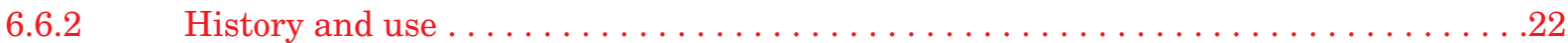

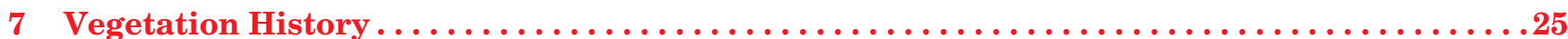

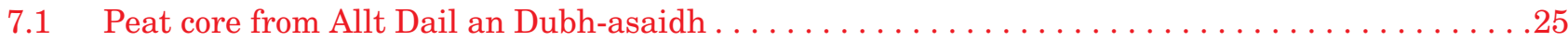

7.2 Other evidence for vegetation history of the Arisaig area $\ldots \ldots \ldots \ldots \ldots \ldots \ldots \ldots \ldots \ldots \ldots \ldots$

8 Occupation and Use of a Marginal Landscape. $\ldots \ldots \ldots \ldots \ldots \ldots \ldots \ldots \ldots \ldots \ldots \ldots \ldots$

8.1 Core and periphery in Arisaig. . . . . . . . . . . . . . . . . . . . . . . . . . . . 27

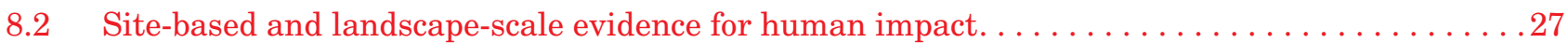

$8.3 \quad$ Evolution of the Arisaig landscape . . . . . . . . . . . . . . . . . . . . . . . . . . . . . . . . .29

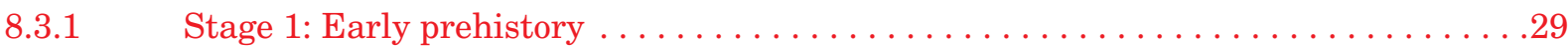

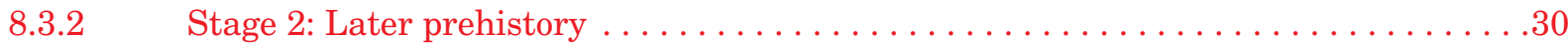


8.3.3

Stage 3: Medieval and later period

.30

8.3.4

Postscript: The recent past.

.30

9 Palynological Analyses at Allt Dail an Dubh-asaidh $\ldots \ldots \ldots \ldots \ldots \ldots \ldots \ldots \ldots \ldots \ldots \ldots$

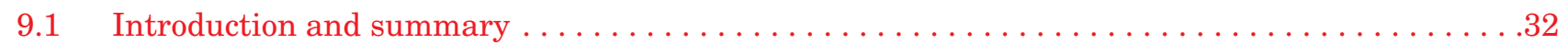

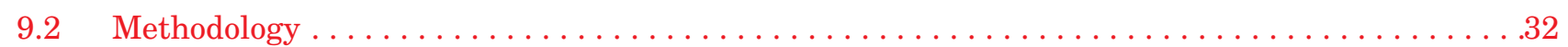

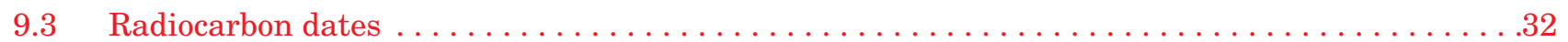

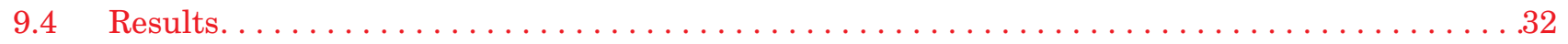

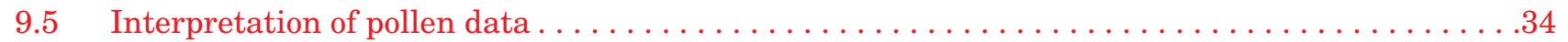

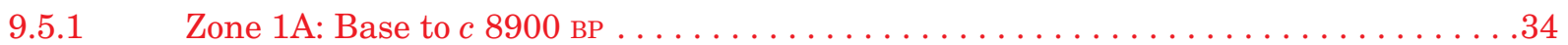

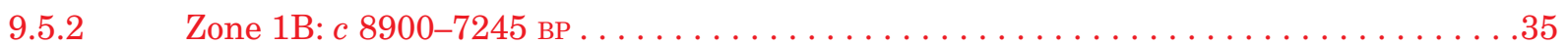

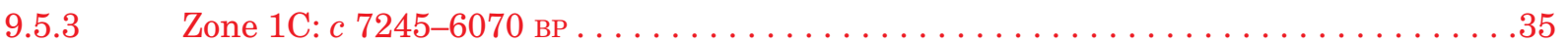

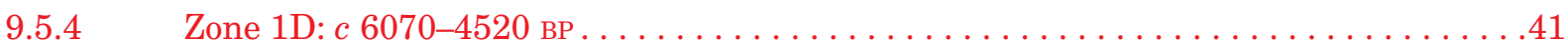

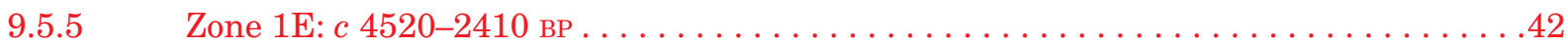

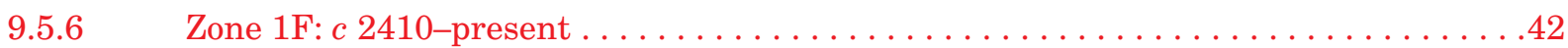

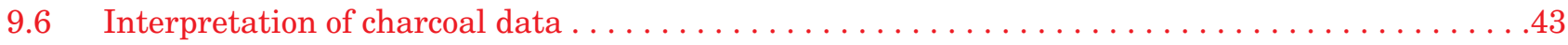

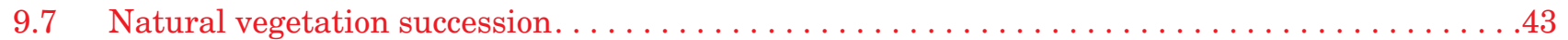

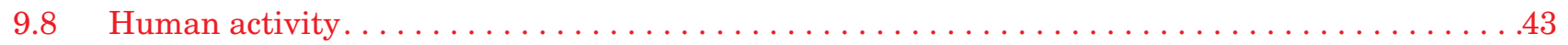

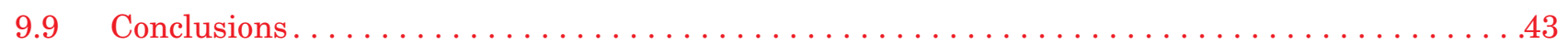

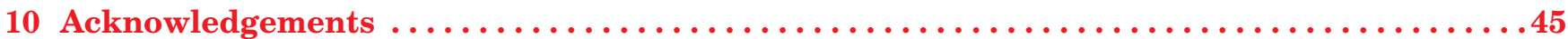

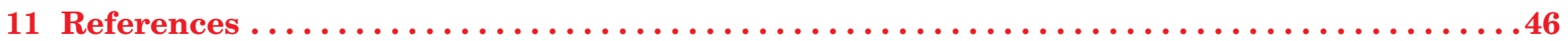




\section{List of illustrations}

Site location (from Ordnance Survey maps @ Crown copyright) $\ldots \ldots \ldots \ldots \ldots \ldots \ldots \ldots \ldots \ldots \ldots \ldots$

Detailed map showing location of pollen sites and known medieval and prehistoric sites (from Ordnance Survey maps $₫$ Crown copyright) . . . . . . . . . . . . . . . . . . . . . . . 3 Map showing site locations along the proposed A830 road placement

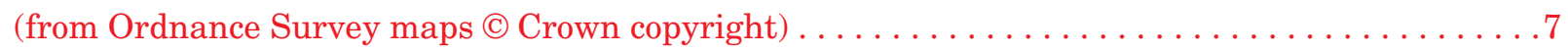
Contour map showing the location of Sites $3-6$ with evaluation and excavation trenches . . . . . 9 View of Site 6 from the south-west. . . . . . . . . . . . . . . . . . . . . . . . . 10

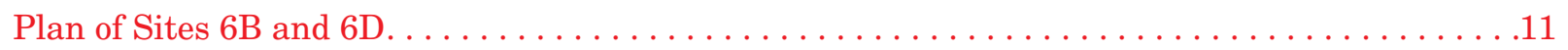

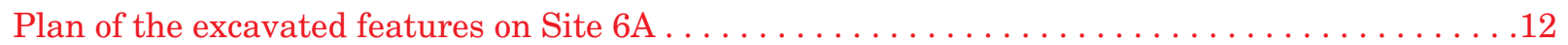

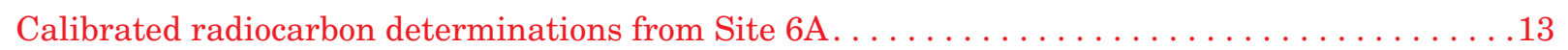

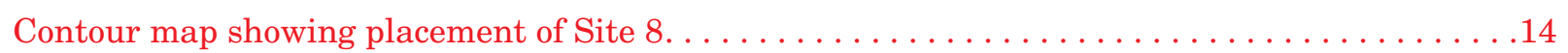

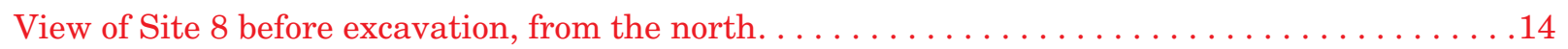

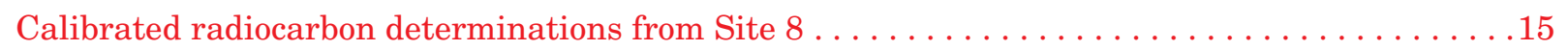

Plan of Site 8: (a) phase I: basal occupation deposit; (b) phase II: lower structure;

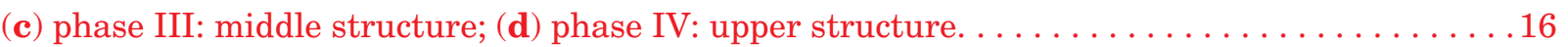

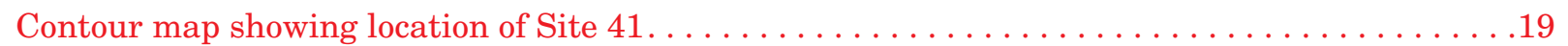

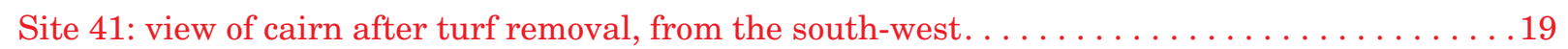

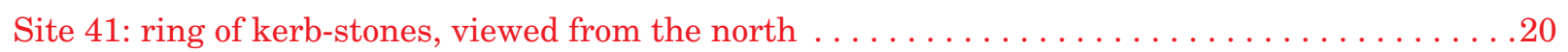

Site 41: plan of kerb and robbed out cist with basal layer of stones $\ldots \ldots \ldots \ldots \ldots \ldots \ldots \ldots 21$

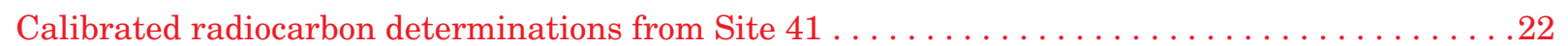

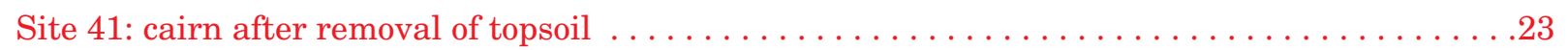

Site 41: sections of the kerb cairn from (a) the north (Profile 1) and (b) the east (Profile 2) . . . 24 Changes in tree pollen percentages from Polnish, Lochan Doilead and

Allt Dail an Dubh-asaidh . . . . . . . . . . . . . . . . . . . . . . . . . . . . 28

Stages of landscape evolution near Arisaig: (a) early prehistory: 7500-3550 BC; (b) later prehistory: $3550 \mathrm{BC}$ to $\mathrm{AD} 500$; (c) medieval and later period: AD 500-1800 (from Ordnance

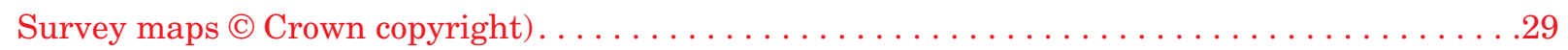

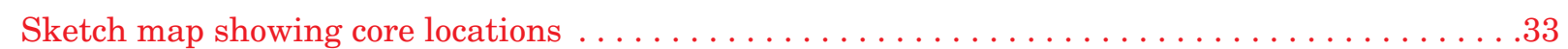

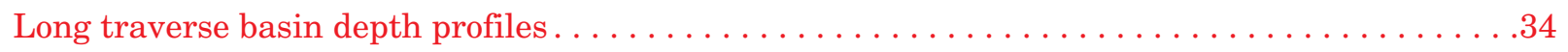
Short traverse basin profiles. . . . . . . . . . . . . . . . . . . . . Allt Dail an Dubh-asaidh: percentage pollen diagrams for (a) trees and shrubs, (b) herbs and (c) acquatics. . . . . . . . . . . . . . . . . . . . . . . . . . . . . . . . . Allt Dail an Dubh-asaidh: pollen concentration curves for (a) trees and shrubs and

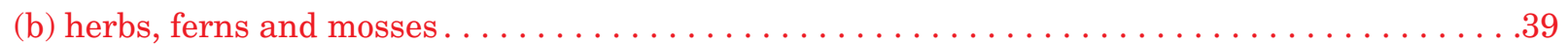
Allt Dail an Dubh-asaidh: pollen condition classes. . . . . . . . . . . . . . . . . . . . . . .41 


\section{List of tables}

1 Radiocarbon determinations of samples from Site $6 \mathrm{~A} \ldots \ldots \ldots \ldots \ldots$

2 Radiocarbon determinations of samples from site $8 \ldots \ldots \ldots \ldots \ldots$

3 Radiocarbon determinations of samples from site $41 \ldots \ldots \ldots \ldots \ldots$

$4 \quad$ Pollen zones, identifying main local and extra-local and regional vegetations types. . . . . . . . 25

5 Pollen zones with radiocarbon dates and accumulation rates $\ldots \ldots \ldots \ldots$

$6 \quad$ Stratigraphic descriptions of pollen core $\ldots \ldots \ldots \ldots \ldots \ldots \ldots$ 


\section{Summary}

Re-alignment of a 6-km section of the A830 road in Arisaig provided an opportunity to investigate the archaeology of this poorly understood area of the West Highlands. A combination of archaeological and palaeoenvironmental techniques were used to investigate the road corridor. Archaeological survey, followed up by selected excavations, identified a previously unrecorded Bronze Age kerb cairn and two areas of shieling huts. Investigation of the shielings obtained evidence for repeated reuse of sites and reconstruction of structures through the medieval and post-medieval periods. In both cases, Bronze Age deposits were also recorded at the base of the medieval sequence. Analysis of a long peat core from a basin close to one of the shielings revealed a history of continuous but gradual decline in woodland, starting in about $3200 \mathrm{BC}$ and continuing to the present day. Collation of archaeological and palaeoenvironmental data from the present project and previous investigations in the area have allowed the creation of a tentative model of landscape evolution for Arisaig. 


\section{Introduction}

Arisaig, together with Moidart to the south and Morar and Knoydart to the north, make up the area traditionally known as na garbh Chriochan: the Rough Bounds (Illus 1). An anonymous writer in 1750 (quoted by Rixon 2002) considered that:

All these countries viz. Knoydart, the Two Morrirs, Moydart, and Arisaig, are the most Rough Mountainous and impassible parts in all the Highlands of Scotland, and are commonly called by the Inhabitants of the Neighbouring countries the highlands of the Highlands.

The construction of the Fort William to Mallaig Road (the 'Road to the Isles', completed in 1812) and the railway that follows the same route (opened in 1901) considerably improved the accessibility of Arisaig and Morar. Knoydart remains one of the least accessible parts of the Scottish mainland, at least if we judge by the standards of our modern car-dependent society.

Progressive upgrading of the road (now the A830) from its former single-track status to modern trunk road standards has been accompanied by archaeo- logical investigations in recent years (eg Rees 1996), in line with current national planning policy guidance. We present the results of a programme of archaeological and palaeoenvironmental investigation carried out during the upgrading of the section of the A830 between the village of Arisaig and Kinsadel at the west end of Loch Morar (Illus 2). This 6 - $\mathrm{km}$ section of road was rebuilt on a totally new line, inland from the existing road, and therefore offered an opportunity to record an undisturbed transect of the landscape. The investigations were carried out by the Centre for Field Archaeology (CFA), University of Edinburgh, and Headland Archaeology Ltd between 2000 and 2001; the road was opened in 2003.

For readers of this paper who know the area well, it should be noted that we use the name Arisaig to refer to coastal land between Loch nan Uamh (Borrodale) in the south and the River Morar in the north. This definition does not precisely match the historic estate of Arisaig as it takes in part of South Morar in the north and excludes parts of Arisaig to the south-east.

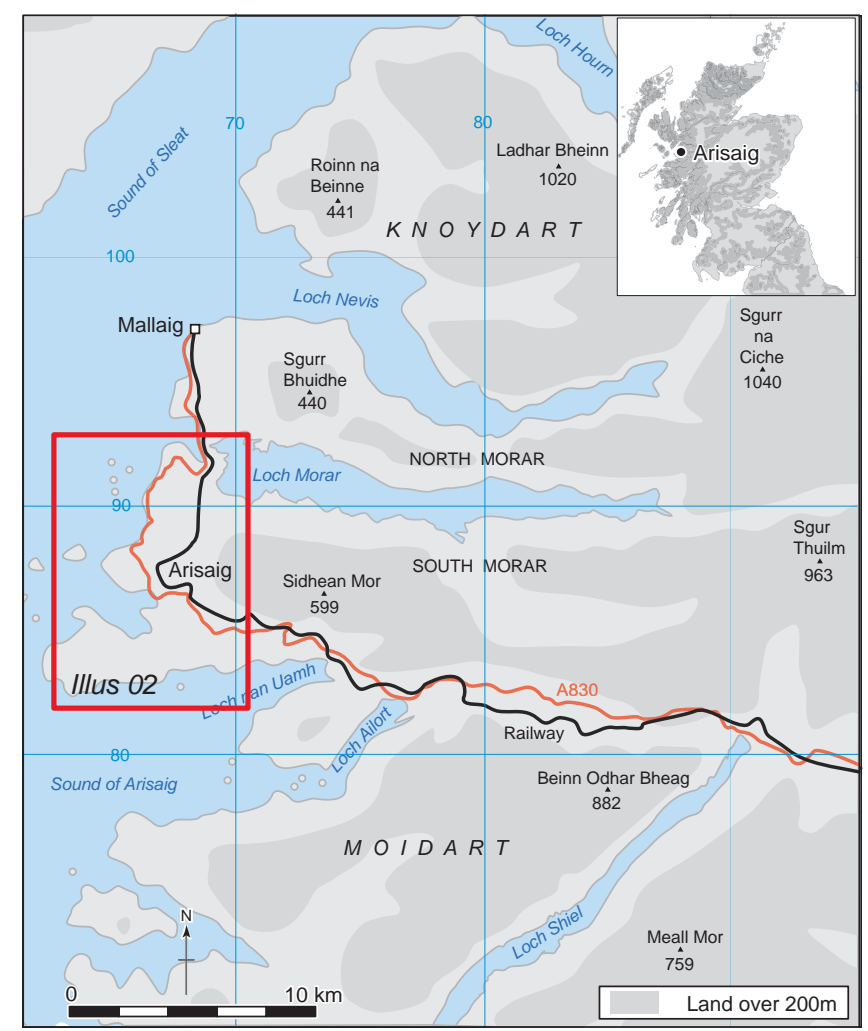

Illus 1 Site location (from Ordnance Survey maps @ Crown copyright) 


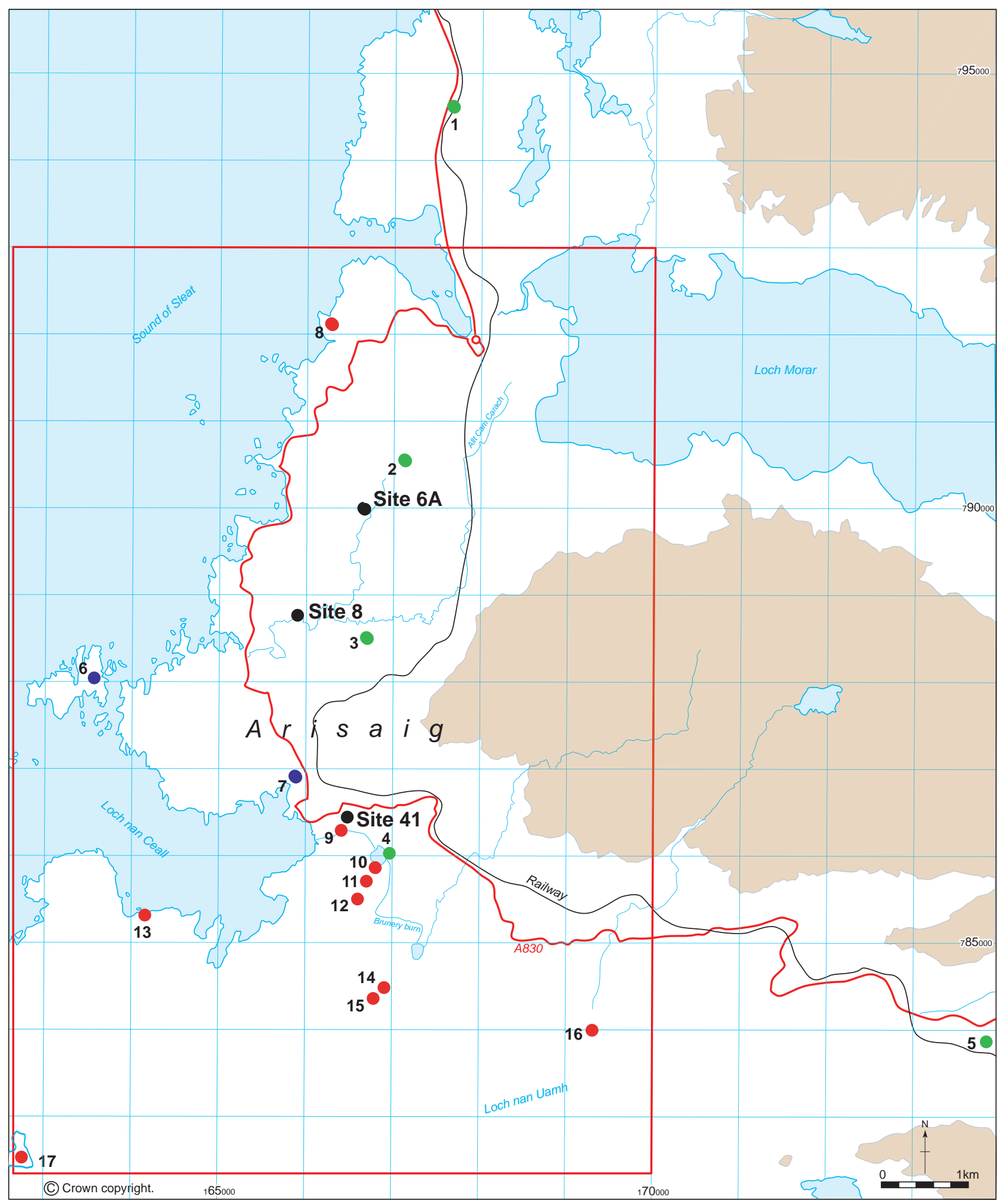

(C) Crown copyright.

165000

\section{Pollen sites}

KEY

1: Lochan Doilhead (Williams 1977)

Pollen site

2: Allt Dail an Dubh-asaidh

- Medieval site

3. Mointeach Mhor (Shennan et al 1994)

- Prehistoric site

4: Loch nan Eala (Shennan et al 1995)

5: Polnish (Clarke 2000)

9. NMRS NM68NE 7: Kerbed caim

1: NMRS NM68NE 4: Oak platform

12: NMRS NM68NE 6: Cairn

13: NMRS NM68NW 9: Promontory fort

14: NMRS NM68SE 1: Cup-marked stone

Archaeological sites

__ Limit of study

6: NMRS NM68NW 1: Stronghold and Corn-Drying Kiln. Medieval or later

7: NMRS NM68NE 1.00: Medieval church

15: NMRS NM68SE 5: Cairn

8: NMRS NM69SE 1: Mixed scatter. Quartz and flint tools. Mezolithic - Bronze Age

16: NMRS NM68SE 2: Promontory fort

17: NMRS NM68SW 2: Fort 


\section{The Archaeology of Arisaig: Early Investigations}

This beautiful but remote part of the west coast of Scotland has received little attention from archaeologists and antiquarians in the past. In part this must reflect an absence of major sites that might attract the attention of distant researchers: there are no visually impressive sites in Arisaig and prehistory is either largely invisible or absent. However, the few discoveries that have been made did attract attention from contemporary investigators. A crannog revealed by the draining of Loch nan Eala was subsequently visited by Reginald Mapleton in 1868 and Odo Blundell in 1911. Mapleton was the Episcopalian minister to the Malcolm family of Poltalloch and is best known for his investigations of archaeological sites in Kilmartin, Argyll. Blundell was one of the pioneers in crannog research in Scotland; he carried out limited excavations in south-west Scotland and the Highlands. Later, the discovery of flint and quartz tools prompted $\mathrm{AD}$ Lacaille to investigate the site in person. Despite these and other records, our knowledge of the archaeology of Arisaig is insubstantial and readily summarized in Illus 2 . Known sites are concentrated in the vicinity of the present village, there is only one site pre-dating the Bronze Age and the medieval period is represented solely by the late medieval church at Kilmory. 


\section{Absence or Invisibility?}

The modest nature of the archaeological record for Arisaig inevitably raises the question of whether this reflects a genuine scarcity or simply a problem of invisibility. Rixon, attempting to describe the prehistoric period in Arisaig and Morar, deals with this question in the following terms:

There are two ways to look at the prehistoric period in Arisaig and Morar: either as an almost blank chapter in which we can do no more than list those prehistoric monuments which have been discovered to date; or as an unopened treasure-chest for the future (Rixon 2002).

Arguments in favour of genuine absence include the fact that the area is dominated by unimproved land where the destruction and levelling of archaeological sites is unlikely to occur: sites, if present, should be visible. The area has been examined by archaeologists, although not subject to recent systematic archaeological survey (as similar areas in Argyll have, for example by RCAHMS), and it seems unlikely that any additional major upstanding monuments exist. Absence of archaeological sites also matches our perception of this area (the 'Rough Bounds') as marginal and capable only of supporting a small human population.

The counter argument for invisibility can draw on the presence of widespread peat deposits, potentially masking prehistoric houses and enclosures, as has been recognized elsewhere along the west coast of Scotland (Ritchie et al 1974). It is also supported by recent high spatial resolution palynological studies in West Affric that have demonstrated the presence of prehistoric farming communities in upland landscapes where no surface archaeological evidence for their former presence has been detected (Davies \& Tipping 2005). This finding requires us to accept that the archaeology of the uplands (or marginal lowland areas) need not be visible, despite the presence of extensive tracts of upstanding prehistoric archaeology in the Highlands of Scotland, or even detectable by conventional archaeological techniques of field survey and excavation.

Weighing up the opposing arguments, it seems likely that neither is wholly correct. The landscape of Arisaig is not uniform and must have offered varying potential for settlement and use by earlier inhabitants. The clustering of recorded archaeological sites correlates with what is currently the better agricultural land so it seems reasonable to propose that there is a real focus of past settlement around the current village of Arisaig. Moving out from this core area into what is currently bog or very rocky grazing land it is reasonable to propose that the absence of archaeological sites is real. 


\section{A Transect Across the Landscape: the Line of the A830 Improvements}

The position of the new road line provided an opportunity to test the idea of a core settlement area in Arisaig surrounded by less-favoured land. The road line starts within the proposed core at its south end and then runs northwards out into an apparently 'blank' area where the archaeological potential might be predicted to be low. The project employed two approaches in the study of this landscape: site-based archaeological investigations of the physical remains of past human activity and palaeoenvironmental investigations of peat deposits to understand human impact on a landscape scale. It was hoped that the two approaches would provide complementary information on how the landscape had been utilized and evolved through time.

It must be stressed that the nature of the project was necessarily opportunistic as the position of the sample transect across the landscape was determined entirely by the position of the new road. Consequently, it displays both the strengths and the weaknesses inherent in a project of this type. On the one hand, the investigation of a road corridor provides an archaeologically random sample of the landscape. It forces the archaeologist to examine ground that would otherwise be passed over on the way to a more promising destination. In these circumstances, the potential for serendipitous discoveries is high as the archaeologist is less able to allow preconceptions to drive the design of the project. On the other hand, a road corridor is unlikely to provide a structured sample of a landscape and will not allow the archaeologist to examine the full range of habitats in an area. In the case of Arisaig, the road line runs parallel to and inland from the coast. As a result, it avoids both the narrow cultivated coastal zone dominated by windblown sand and the higher hills that lie inland. We therefore collected no new data on these habitats and this has limited our ability to understand the evolution of the landscape as a whole. 


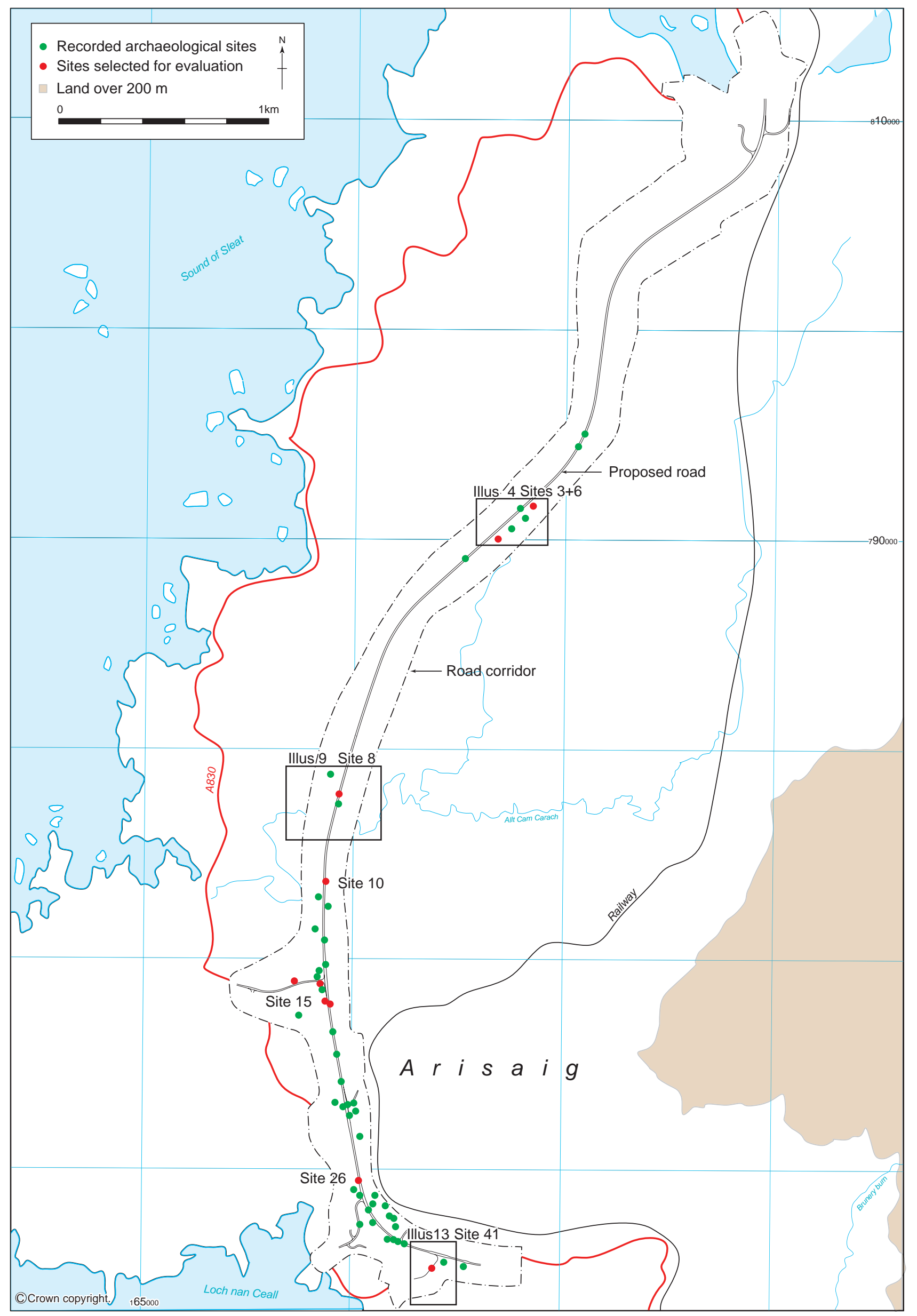




\section{The Archaeological Investigations}

The programme of archaeological works took a typical staged approach and was designed to test and then investigate the archaeological potential of the route. The initial stages included a desk-based study followed by a walkover survey of the road line. This identified 44 visible features; the vast majority were clearly structures of 19 th and 20 th century date and these were concentrated at the south end of the route within the proposed core area (Illus 3). The potential for invisible sub-surface archaeological features was tested in two ways. Engineers' test pits were monitored at intervals of $75 \mathrm{~m}$ and the southern $3 \mathrm{~km}$ of the route was monitored during topsoil stripping. Nothing of interest was noted in the test pits and only one undated pit was identified during the topsoil strip.

Seven of the sites identified during the survey were selected for further evaluation as they were either of potentially early date (pre-19th century) or might conceal earlier features (Illus 3). Three of these sites were then subject to more substantial excavation on the basis of the evaluation results.

\subsection{Shieling huts and circular stone features: Sites 3-6 (centred on NM 6675 9005)}

\subsubsection{Survey}

A group of sites was recorded on a south-east facing hillside beside a small stream, the Allt Dail an Dubh-asaidh, on the north side of the Mointeach Mhór (Illus 4). The hillside contains pockets of deeper soil, now largely covered in bracken, in amongst extensive rocky outcrops partly covered in heather (Illus 5). There are more extensive areas of deeper soil along the stream, also bracken-covered. The structures were located in these areas of deeper soil; they included a small enclosure, the footings of six small sub-rectangular buildings (Sites $3 \mathrm{~A}-\mathrm{E}$ and 6C) identified as shieling huts, and three circular stone features $2-3 \mathrm{~m}$ in diameter and of uncertain function (Sites 6A, 6B and 6D). The shieling huts measured up to $3 \mathrm{~m}$ by $4 \mathrm{~m}$ and were defined by low turf and stone banks spread to $1.5-2 \mathrm{~m}$ wide and up to $0.4 \mathrm{~m}$ high.

The ruin of a 19th-century building (Site 5) was situated on level ground between Sites 3 and 6 . It was $3 \mathrm{~m}$ wide by $16 \mathrm{~m}$ long and subdivided into three rooms. This structure is marked as a sheepfold on the First Edition OS map surveyed in 1873. However, the walls at the north end were up to $2 \mathrm{~m}$ high and built from well-fitted faced stones. It appears that the structure was a building (farmstead?) that later was reused as a sheepfold. To the north of the building there was an area of cultivation rigs that was probably contemporary with the building. The cultivation remains covered an area $30 \mathrm{~m}$ by $90 \mathrm{~m}$ and comprised rigs $1.5-2 \mathrm{~m}$ wide. By 1873 , they had been abandoned and a stone dyke (Site 4) had been built across the rigs.

\subsubsection{Evaluation}

Four structures were investigated further. Evaluation trenches were cut through examples of shieling huts (Sites 3A and 6C) and two of the circular stone features (Sites 6A and B).

The evaluation trenches across the two shieling huts exposed the footings of turf and stone walls. No traces of any occupation deposits were seen above the natural subsoil nor were any artefacts retrieved. The size and shape of the structures indicated that they represented remains of shieling huts and the absence of artefacts suggested an 18th-century or earlier date (19th-century structures elsewhere along the road line contained abundant pottery, glass and metalwork).

The two circular stone features (Sites 6A and 6B) were found to be sitting on and within the upper layer of turf and topsoil (Illus 6). No artefacts were retrieved and their date and purpose remained uncertain. The two examples of rings of stones (Sites 6B and 6D) are similar to features recorded during a survey of the Tangaval peninsula by University of Sheffield (Branigan \& Foster 1995). Here they have been interpreted as weights to hold down a temporary tent-like shelter for a herdsman. This interpretation could not apply to the third site (6A), which is a circular area of flat stones. An alternative interpretation for this, and the other two rings, is that they are bases for peat stacks - fuel for the occupants of the shieling huts or the farmstead.

During the excavation of the trench across Site 6A, a thin lens of charcoal was encountered, $0.25-0.35 \mathrm{~m}$ below the ground surface; the charcoal deposit was apparently not associated with the stone structure seen on the surface. A sample was taken from the deposit for radiocarbon dating (AA-41068/GU-9251) and produced a 15th century AD date and, on the basis of this result, an excavation was carried out to further investigate its context.

\subsubsection{Excavation (Illus 7)}

The deposits within the excavated area were 0.4$0.6 \mathrm{~m}$ deep down to bedrock and natural sand 


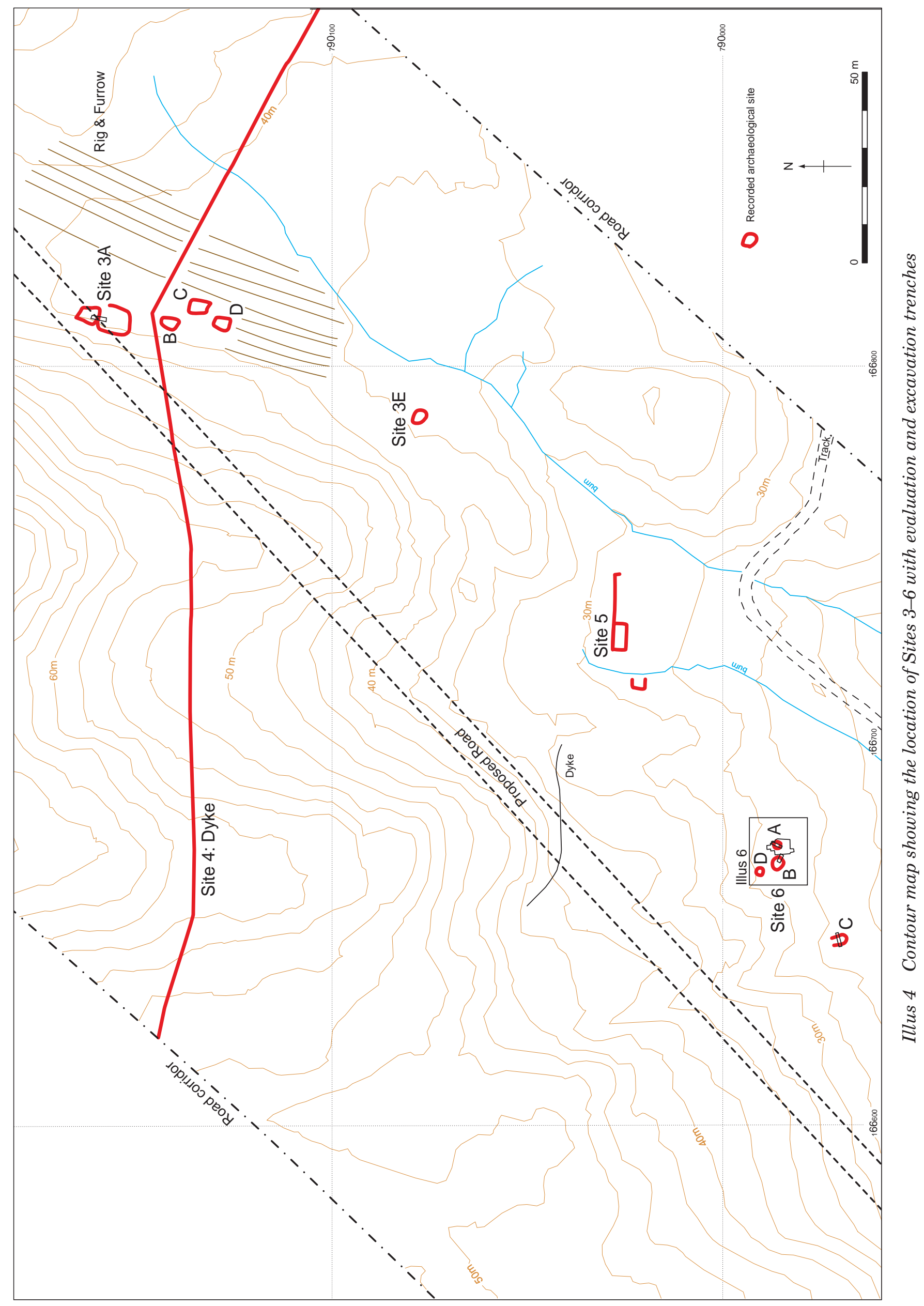




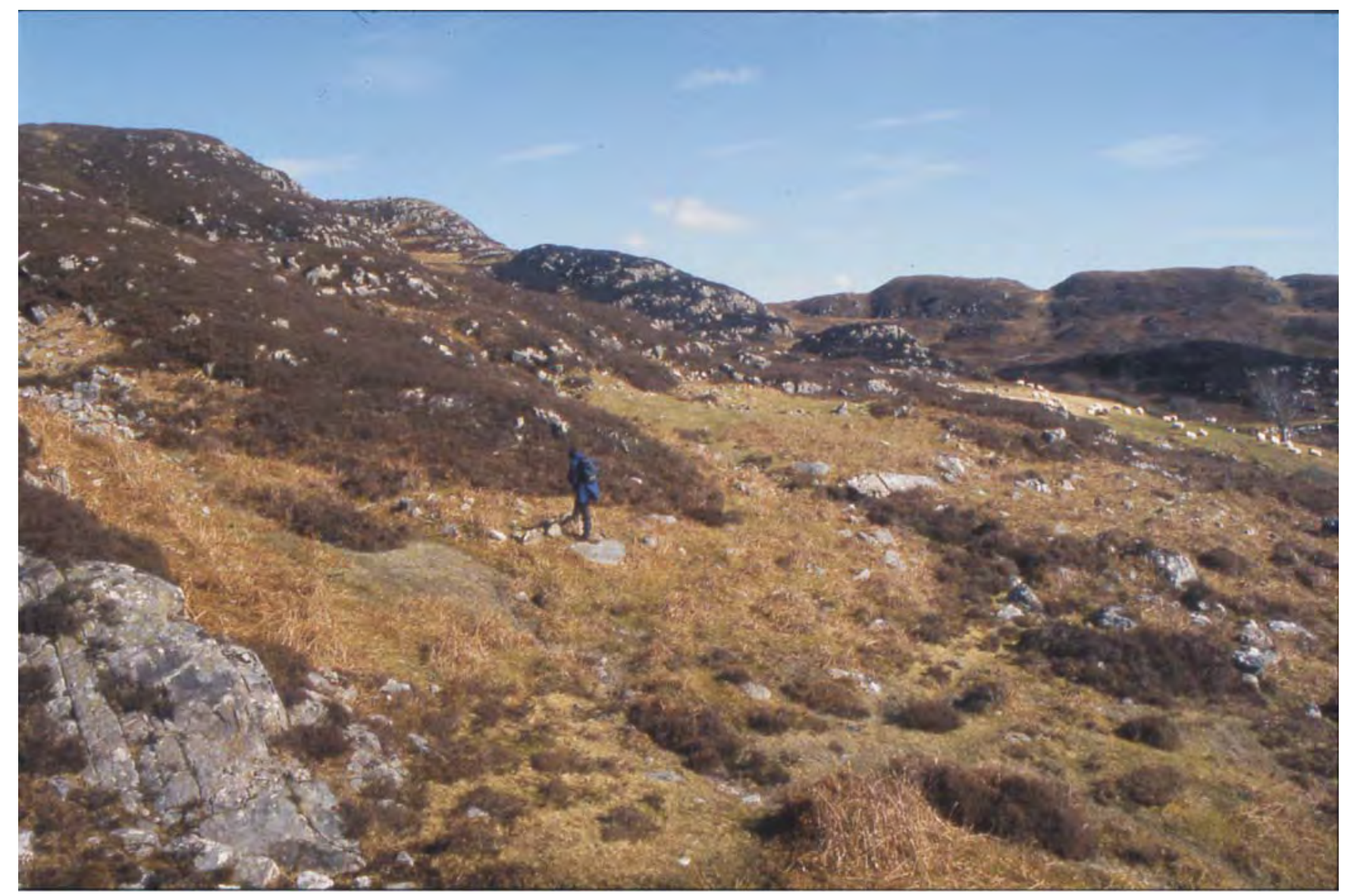

Illus 5 View of Site 6 from the south-west

(context 663). In the north-eastern part of the trench there was a thin deposit of patchy black sandy silt with abundant charcoal (context 662) on top of bedrock and sealed by a layer of black friable peat underlying a deposit of sandy silt. A shallow oval pit or scoop (context 653) was cut into the sandy silt layer. The cut of this pit was not clear and its outline was best defined by its basal deposit of charcoal in a matrix of dark brown silty clay (context 654).

The pit was sealed by a deposit of mid yellowishbrown sandy silt (context 657) with sparse subangular cobbles and rare charcoal flecks throughout. A few fragments of charred hazelnut shell were retrieved from a sample taken from the deposit. The layer underlay a spread of dark brownish-grey silty clay with charcoal flecks (context 650). This deposit was $0.09 \mathrm{~m}$ deep and filled a shallow depression. No artefacts were retrieved from the layer, but small fragments of burnt bone and hazelnut shell were retrieved from a sample. The sample also produced a small quantity of oat grains. Context 650 was cut by an oval pit (context 651); the lower fill of this pit (context 608/652) was the charcoal-rich deposit recorded during the evaluation and dated to the 15 th century AD. In addition to charcoal, that deposit (context 608/652) also contained a few oat grains. The upper fill of the pit comprised light brown silty sand (context 664).
To the west of the pit, also overlaying context 650 , was a linear stone feature (context 655), running roughly north to south. It comprised a row of flat stones $0.2-0.5 \mathrm{~m}$ across. The feature petered out towards the southern edge of the trench, but continued northwards into an area of natural tumbled stones and boulders where it seemed to end. The exposed part of the feature measured some $6 \mathrm{~m}$ north-south. It was covered by turf and topsoil and underlay the surface circular stone feature (Site $6 \mathrm{~A})$.

A further three radiocarbon samples were submitted for dating. These had been taken from the basal charcoal deposit (context 662), the fill (context 654) of the lower pit (context 653) and from the spread (context 650). This spread was cut by the upper pit (context 651/608), from which the radiocarbon sample had been taken during the evaluation. The results are presented in Table 1 and Illus 8.

The date from the basal deposit (context 662) indicates that there was activity in the area during the Bronze Age. However, no features were recorded within the trench that could be associated with this deposit. The layer of peat that sealed the Bronze Age remains must have formed over the site during the following 2000 years before activity again resumed in the early medieval period. The three later dates 
Table 1 Radiocarbon determinations of samples from Site 6A

\begin{tabular}{|c|c|c|c|c|c|c|}
\hline Lab code & Context & Material & Lab age BP & $\delta \mathbf{C 1 3}$ & 1 sigma cal & 2 sigma cal \\
\hline $\begin{array}{l}\text { SUERC-2441 } \\
\text { (GU-11898) }\end{array}$ & 662 & Quercus & $3055 \pm 40$ & $-25.6 \%$ & $1390-1260$ вс & $\begin{array}{l}1420-1210 \text { вс }(93.0 \%) \\
1200-1190 \text { вС }(1.2 \%) \\
1140-30 \text { вс }(1.2 \%)\end{array}$ \\
\hline $\begin{array}{l}\text { SUERC-2443 } \\
\text { (GU-11899) }\end{array}$ & 654 & Corylus & $1115 \pm 40$ & $-23.5 \%$ & $\mathrm{AD} 890-985$ & $\begin{array}{l}\mathrm{AD} 780-800(1.8 \%) \\
\mathrm{AD} 810-1020(93.6 \%)\end{array}$ \\
\hline $\begin{array}{l}\text { SUERC-2444 } \\
(\text { GU-11900) }\end{array}$ & 650 & Quercus & $840 \pm 45$ & $-25.7 \%$ & $\mathrm{AD} 1160-1260$ & $\begin{array}{l}\mathrm{AD} 1040-1100(11.2 \%) \\
\mathrm{AD} 1110-1290(84.2 \%)\end{array}$ \\
\hline $\begin{array}{l}\text { AA-41068 } \\
(\text { GU-9251) }\end{array}$ & $\begin{array}{l}608 / \\
652\end{array}$ & Quercus & $440 \pm 35$ & $-26.0 \%$ & AD 1435-65 & $\mathrm{AD} 1418-88$ \\
\hline
\end{tabular}

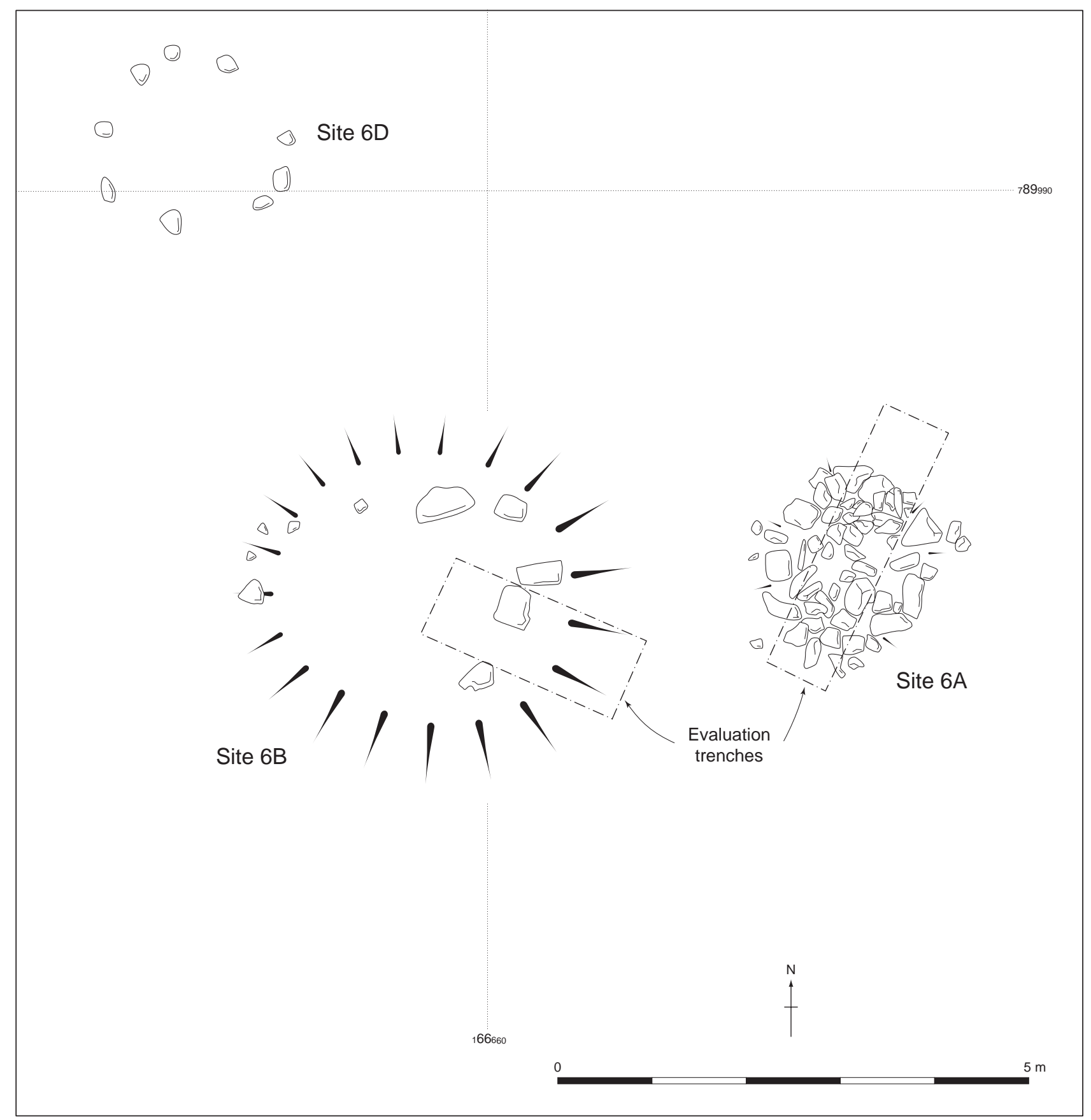

Illus 6 Plan of Sites $6 B$ and $6 D$ 


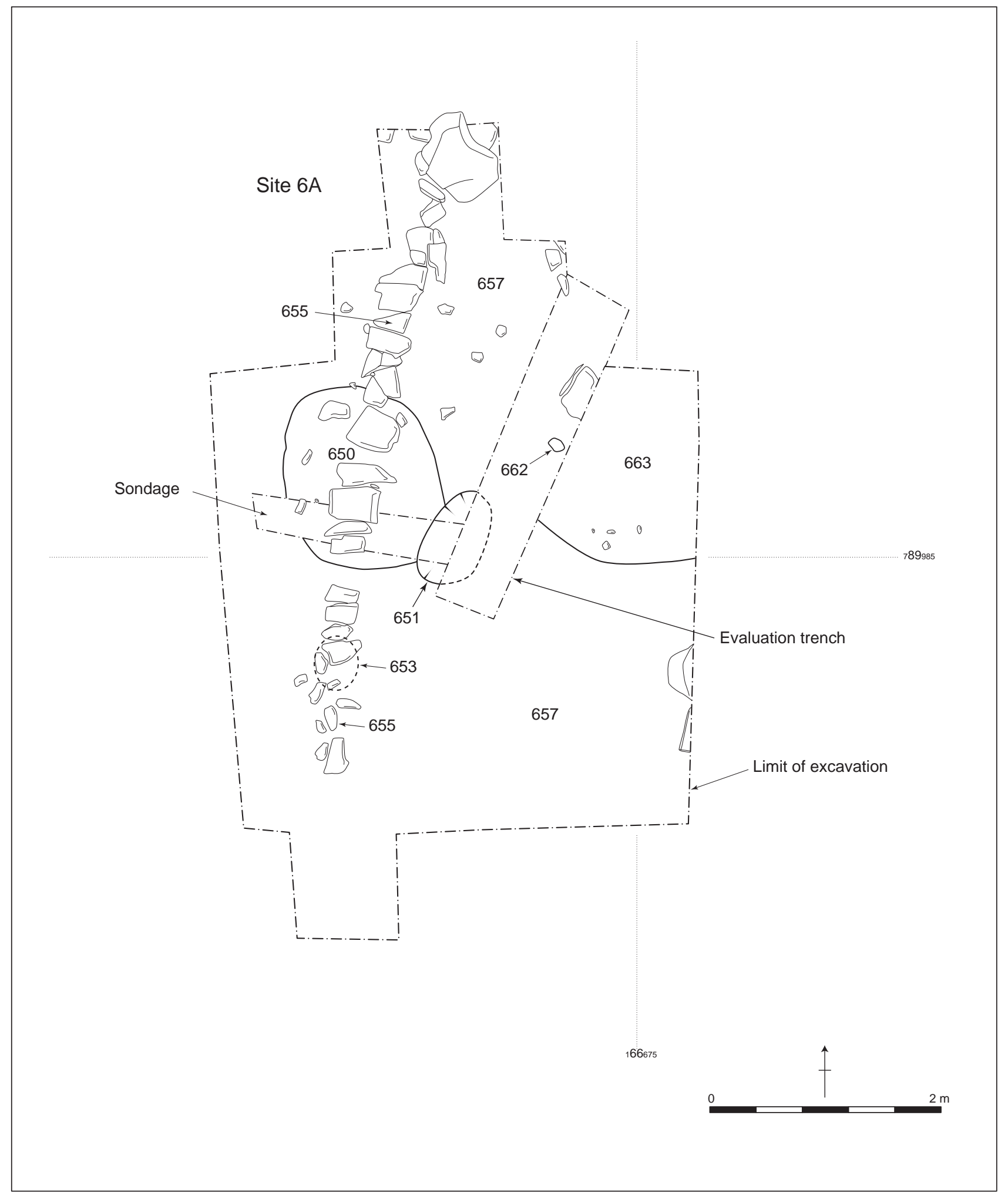

Illus 7 Plan of the excavated features on Site $6 A$ 


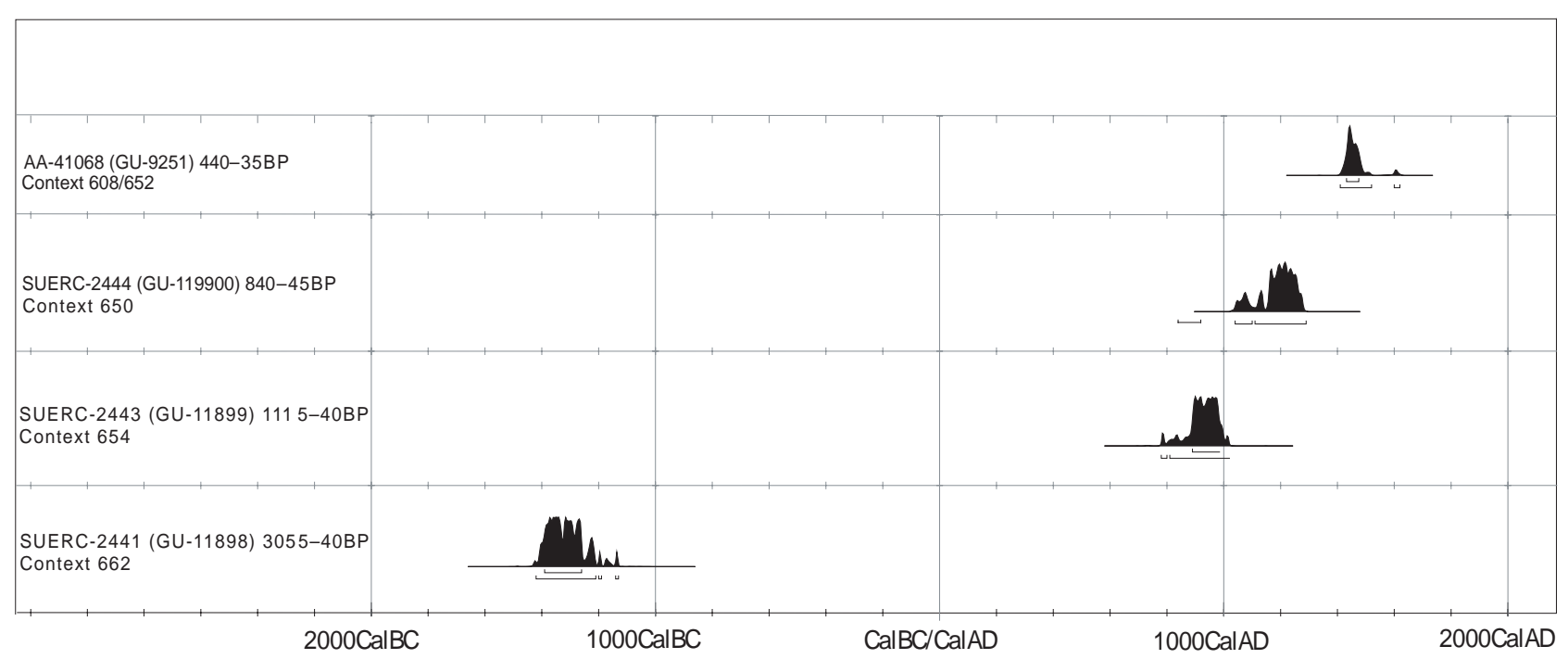

Illus 8 Calibrated radiocarbon determinations from Site $6 A$

indicate that there were episodes of activity throughout the medieval period. Apart from the pits, the only feature that could be associated with this activity was the linear stone feature (context 655), which could have been contemporary with context 651 , the late medieval pit. The circular stone features are clearly later than the 15 th century $\mathrm{AD}$ but it is not known by how long a period.

\subsubsection{Reuse of temporary sites from prehistory}

The results of the excavation show that the area was used in the middle Bronze Age. The nature of the remains give us no clues as to the nature of the activity at this time and it is not even certain that the dated feature is the product of human activity. The next evidence of activity in the area was dated to the ninth and tenth centuries AD. Again the evidence is limited, but a series of stratified features produced dates indicating that the site was in continuous use or repeatedly re-visited through the medieval period. The presence of oat grains in the medieval deposits suggests that food was prepared and consumed at the site but positive evidence for the reason behind this is not available. The deposition of a substantial volume of mineral sediment over the post-Bronze Age peat soil in the medieval period requires explanation and suggests that we may have dug through the highly dispersed remains of unsubstantial turf and timber structures, essentially a stack of turf shieling huts, spanning the medieval period. The line of stones could then be interpreted as a wall foundation.

In this case, the adjacent shieling hut (Site 6C) is simply the most recent hut to be built on the site and, together with the huts at Site 3, represents the continued use of a summer shieling in the area into the post-medieval period. If this interpretation is accepted then the presence of a 19th century farmstead marks a significant change of land use from summer grazing to permanent settlement. However, this change appears to have been short-lived as by the later 19th century the building had been converted into a sheepfold and the area reverted to pasture. This land use has continued up to the present day.

\subsection{Shieling huts and cultivation rigs: Site 8 (centred on NM 659 888)}

\subsubsection{Survey}

The site was located on rocky ground on the west side of Mointeach Mhór, some $50 \mathrm{~m}$ to the north of Allt Cam Carach. It comprised an extensive complex of cultivation rig remains covering an area of some $100 \mathrm{~m}$ by $200 \mathrm{~m}$ (Illus 9 ). At the north-west of this area there were turf and stone footings of a subrectangular shieling hut measuring $8 \mathrm{~m}$ by $4.5 \mathrm{~m}$ overall. A small rectangular annexe $1.5 \mathrm{~m}$ by $3.5 \mathrm{~m}$ was situated immediately to the north. A third structure was situated at the south-eastern limit of the cultivated area. It was defined by a discontinuous line of stones along the edge of a platform, $2.5 \mathrm{~m}$ by $4 \mathrm{~m}$, set up against a vertical rock face (Illus 10). Of the three structures, only this one was directly in the line of the new road.

\subsubsection{Evaluation}

To investigate this platform further, an evaluation trench was cut across the feature. A charcoal layer was exposed at the base of the trench, $0.55 \mathrm{~m}$ below the surface, and was dated to the Bronze Age (AA-41069/GU-9252). On the basis of this date, further excavation was carried out. 


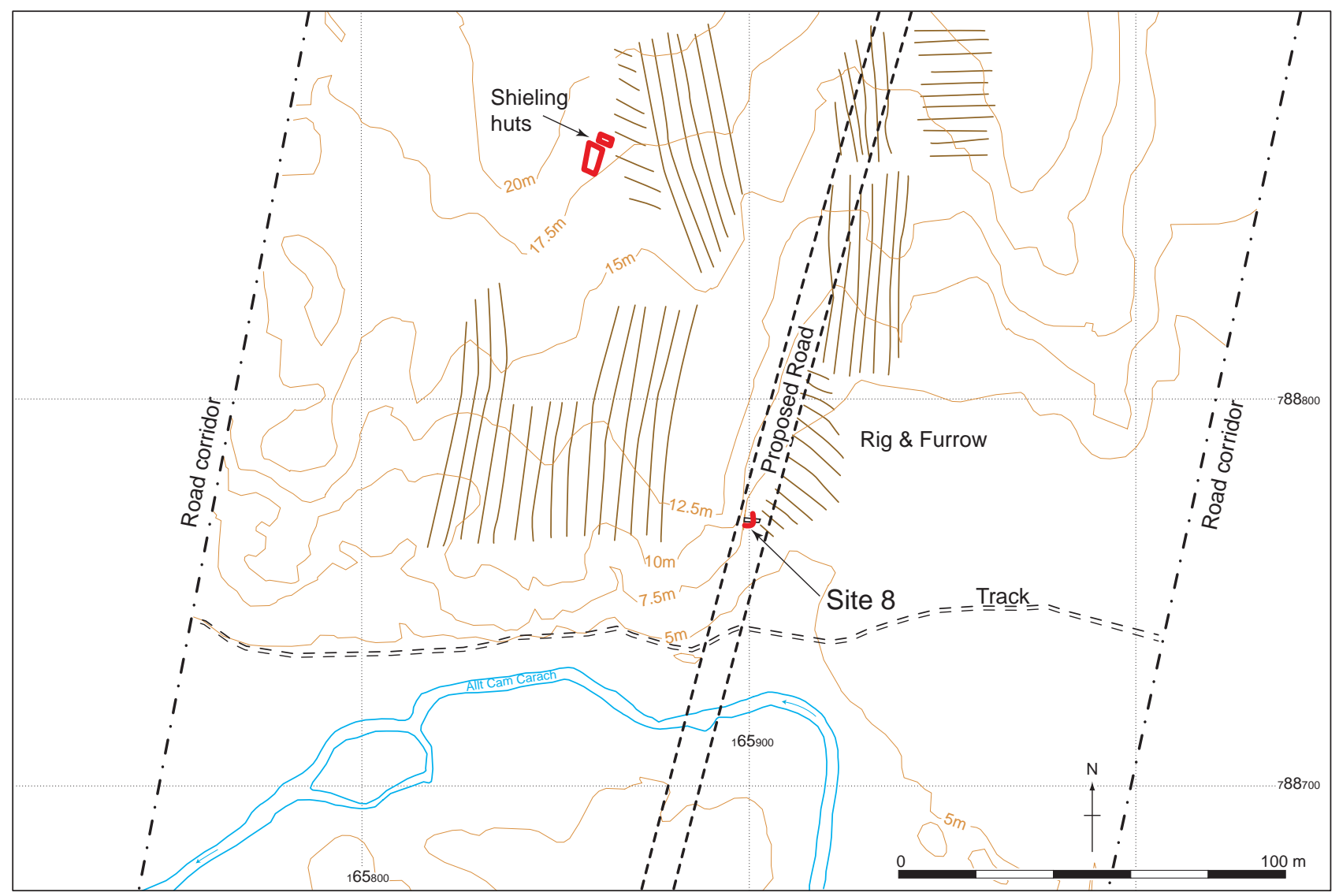

Illus 9 Contour map showing placement of Site 8

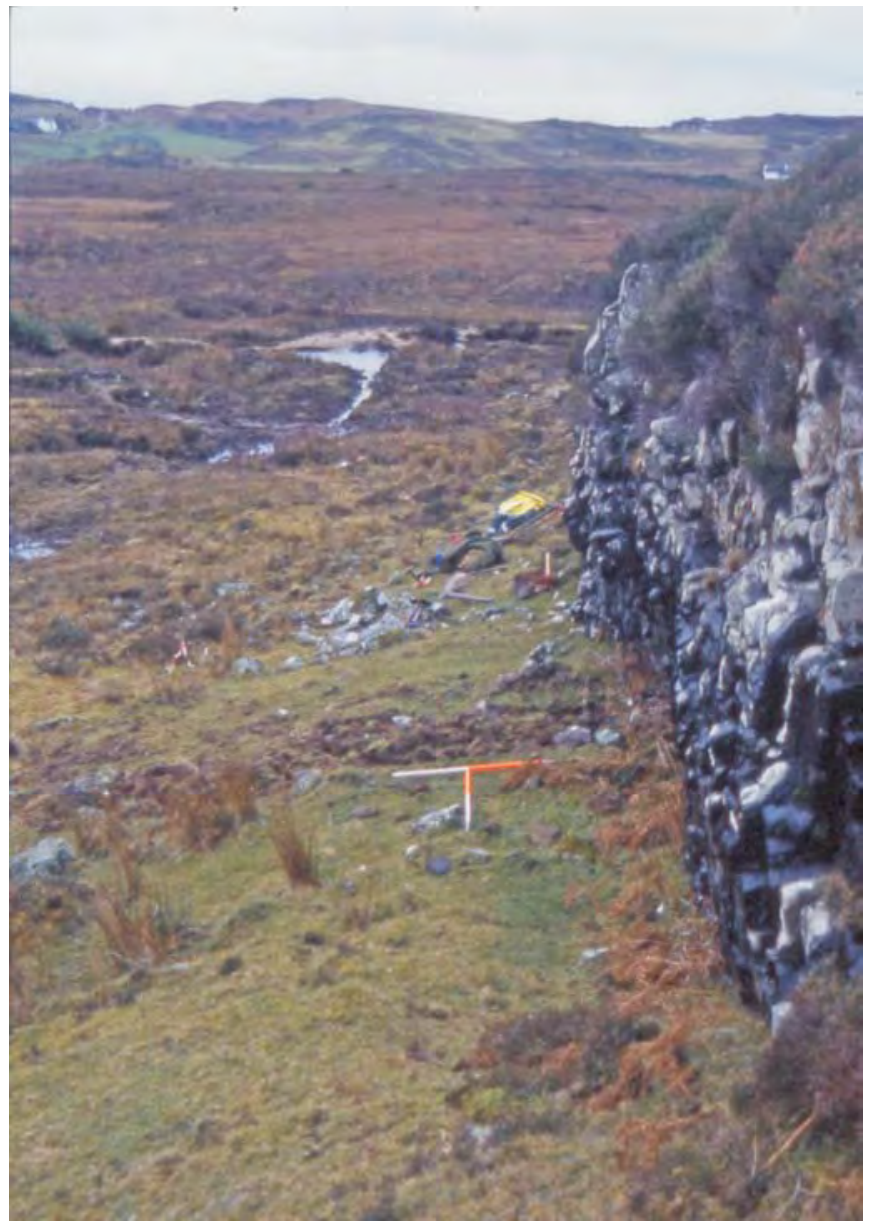

\subsubsection{Excavation}

A $4 \mathrm{~m}$ by $5 \mathrm{~m}$ trench was opened up against the foot of the rock face, centred on the evaluation trench. The stratigraphy of the site can be grouped into five structural phases; of these the lower four were dated by radiocarbon (Table 2 and Illus 11).

\section{Phase 1: Basal occupation deposit (Illus 12a)}

The basal deposits in the trench comprised two areas of dark brownish-grey silty sand (context 868, with concentrations of charcoal overlying mid yellow to brown sand; context 864, natural subsoil). Context 868 was the same sediment as context 803 , which was sampled during the evaluation and dated to between the 11th and 14th centuries BC. One quartz flake was retrieved from this context but there were no features associated with it. A general layer of yellowish-brown silty sand with occasional fragments of charcoal sealed the occupation deposits. It was interpreted as a deposit formed by natural processes, probably hillwash from the slope to the north.

Illus 10 (left) View of Site 8 before excavation, from the north 
Table 2 Radiocarbon determinations of samples from Site 8

\begin{tabular}{|c|c|c|c|c|c|c|}
\hline Lab code & Context & Material & Lab age $B P$ & $\delta \mathbf{C 1 3}$ & 1 sigma cal & 2 sigma cal \\
\hline $\begin{array}{l}\text { AA-41069 } \\
\text { (GU-9252) }\end{array}$ & $803=868$ & Quercus & $2990 \pm 45$ & $-26.3 \%$ & $1366-1129$ вС & $1386-1049$ вС \\
\hline $\begin{array}{l}\text { SUERC-2445 } \\
\text { (GU-11901) }\end{array}$ & 865 & Pomodieae & $380 \pm 40$ & $-23.2 \%$ & $\begin{array}{l}\mathrm{AD} 1440-1530(48.9 \%) \\
\mathrm{AD} 1590-1630(19.3 \%)\end{array}$ & $\begin{array}{l}\mathrm{AD} 1440-1530(55.1 \%) \\
\mathrm{AD} 1540-1640(40.3 \%)\end{array}$ \\
\hline $\begin{array}{l}\text { SUERC-2446 } \\
\text { (GU-11902) }\end{array}$ & 861 & Corylus & $245 \pm 40$ & $-27.5 \%$ & $\begin{array}{l}\text { AD } 1530-50(6.6 \%) \\
\text { AD } 1630-80(39.0 \%) \\
\text { AD } 1770-1810(18.9 \%) \\
\text { AD } 1930-50(3.8 \%)\end{array}$ & $\begin{array}{l}\text { AD } 1510-1600(18.9 \%) \\
\text { AD } 1620-90(42.6 \%) \\
\text { AD } 1730-1810(28.2 \%) \\
\text { AD } 1920-50(5.7 \%)\end{array}$ \\
\hline $\begin{array}{l}\text { SUERC-2450 } \\
\text { (GU-11903) }\end{array}$ & 859 & Corylus & $175 \pm 40$ & $-27.1 \%$ & $\begin{array}{l}\text { AD } 1660-90(12.5 \%) \\
\text { AD 1730-1810 (43.0\%) } \\
\text { AD } 1920-50(12.7 \%)\end{array}$ & $\begin{array}{l}\mathrm{AD} 1650-1890(79.3 \%) \\
\mathrm{AD} 1910-60(16.1 \%)\end{array}$ \\
\hline
\end{tabular}

\begin{tabular}{|l|l|l|l|l|}
\hline \\
SUERC-2450 (GU-11903) 175-40BP \\
Context 859
\end{tabular}

\section{Illus 11 Calibrated radiocarbon determinations from Site 8}

\section{Phase 2: Lower structure (Illus 12b)}

On top of the hillwash were the remains of a structure that comprised the base of a straight wall (context 866) set at a 45-degree angle against the rock face. This wall appeared to be a windbreak forming a shelter open to the south. It enclosed a deposit of dark brownish-grey silty sand with charcoal and grains of hulled barley (context 865). A sample of charcoal taken from context 865 was dated to the 15 th or 16 th century AD. A layer of stony brown silty sand (context 863), thought to be levelled wall material from the shelter wall, covered the wall footing and deposit.

\section{Phase 3: Middle structure (Illus 12c)}

On top of the levelled wall material were the remains of a smaller structure. It was defined by wall footings comprising a curving band of angular to sub-angular stones (context 862), which formed an area $1.5 \mathrm{~m}$ by $2.5 \mathrm{~m}$ against the rock face with an entrance to the north. The wall enclosed a layer of dark brown clayey silt (context 861), which contained some charcoal and grains of hulled barley; it is interpreted as the occupation deposit associated with the structure. A radiocarbon date for this structure derives from a charcoal sample taken from the occupation deposit. The calibrated date is not very precise due to the shape of the calibration curve at this point; the probability density is distributed over four distinctive peaks between $\mathrm{AD} 1530$ and 1950 at 1 sigma probability (Illus 11). However, consideration of the date of stratigraphically related samples indicates that it is not likely to date to the 20th century or the 16 th century. It is therefore most likely that the date of the structure lies within the two middle peaks and dates to the 17 th or 18 th century $\mathrm{AD}$.

\section{Phase 4: Upper structure (Illus 12d)}

Immediately on top of the middle structure were the remains of a third construction of similar shape and style of construction. It was defined by the remains of a wall comprising a curving line of angular to sub-angular stones (context 852). The structure occupied the same spot, but enclosed an area of $8 \mathrm{~m}^{2}$, twice that of the previous structure. As before, the entrance was at the north. At the north end of the structure there was a small patch of mid brown sandy loam with a high concentration of charcoal (context 859). Inside and partly over the wall, there was a layer of mid brown sandy silt (context 856) markedly less stony than the layers above. This 


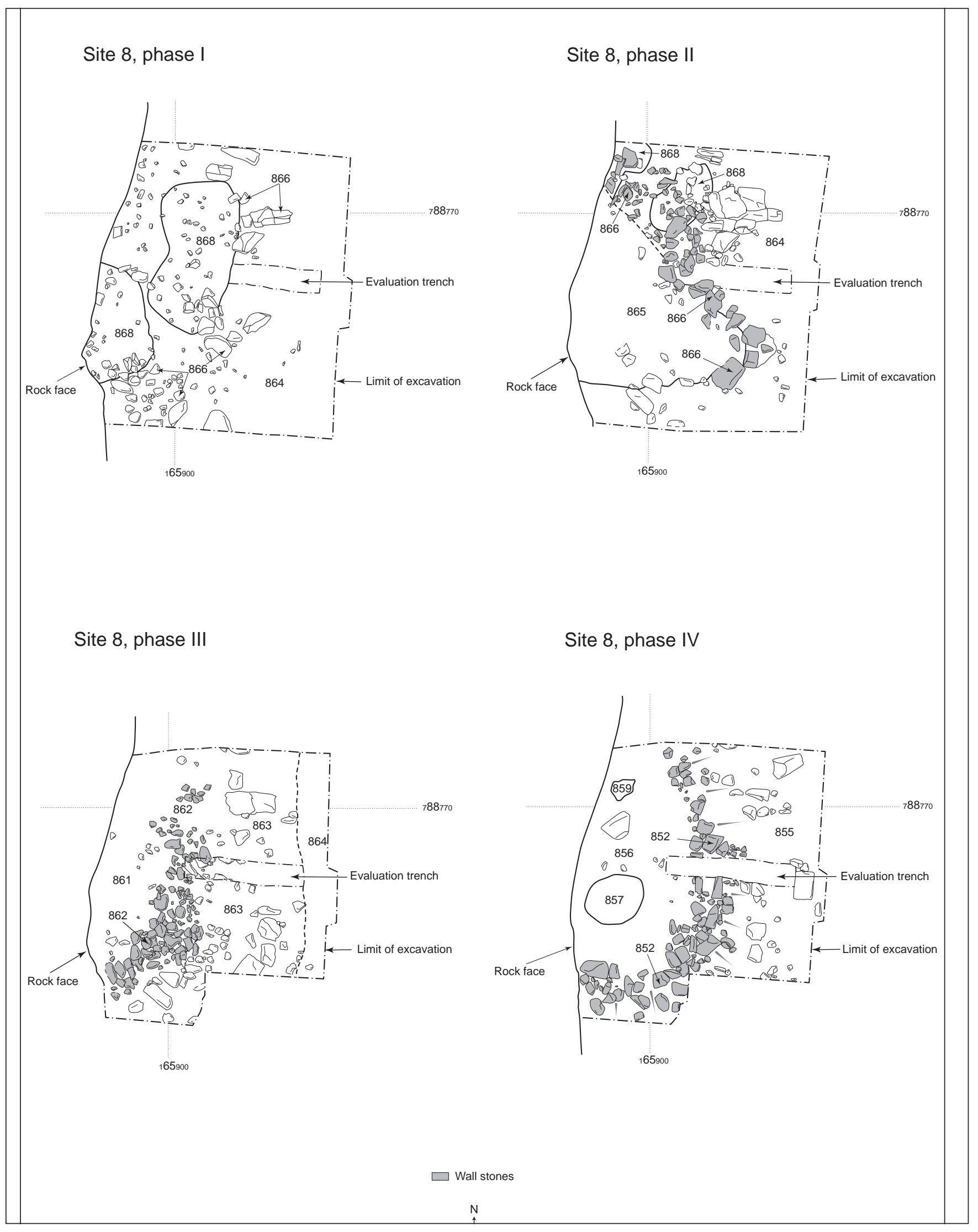

Illus 12 Plan of Site 8: (a) phase I: basal occupation deposit; (b) phase II: lower structure; (c) phase III: middle structure; (d) phase IV: upper structure. 
deposit was thought to be decomposed turfs from the walls of the structure.

The structure was dated from a sample of charcoal taken from context 859. Again the calibrated radiocarbon date indicates a wide date range between $\mathrm{AD} 1660$ and 1950, with the probability distributed over four peaks (Illus 11). However, as before, a 20th century date can be ruled out, suggesting the structure dates to the 17 th, 18 th or 19 th century AD.

\section{Phase 5: Late features}

The remains of the three structures formed a platform up against the rock face.

In the middle of this platform was an oval deposit of dark greyish-brown sandy silt (context 857) filling a shallow hollow. This was sealed by an area of packed stones (context 854) with a stone spread (context 853) to the north, forming the upper level of the platform. These stones were covered by turf and topsoil (context 851). The stone spread seems to be a rough surface created up against the rock shelter but not associated with any surviving superstructure. This phase was given an upper age limit by finds retrieved from the top of the stones that comprised fragments of at least three glass vessels. These were all dated to the 20th century, not earlier than the 1920s (A Cox, pers comm).

\subsubsection{Lithics by $C$ Wickham-Jones}

A small lithics assemblage (36 pieces) was retrieved from Site 8. It largely comprised quartz flakes and chunks and one quartz core. Some of these may be natural, but it is more likely, given the presence of worked quartz, that they all either result from local knapping or have been brought on to the site as potentially useful. The quartz is a tabular, vein quartz that is presumably eroding out somewhere in the locality. One large chunk has been used as a core indicating that some quartz working took place on, or near to, the site. There are 18 quartz flakes, most of them broken. Breakage is probably a result of the friable nature of the raw material and may have taken place during knapping. Many of the flakes are of a good size and they would have been quite suitable for use.

In addition, two pieces of flints were retrieved. One is a broken bifacial point; the other a small broken flake. The assemblage also contains one flake of bloodstone that must have come from Rùm. Rùm bloodstone was used across a wide area of the west coast of Scotland from the Mesolithic onwards.

The lithics assemblage was retrieved from contexts associated with all five phases, but mainly from contexts 856 and 863 (Phases 2 and 4). It is not thought that the lithics assemblage dates from the 16 th to 20 th centuries $\mathrm{AD}$ and must therefore have been re-deposited in all but the earliest (Bronze Age) sediments. The two sediments that produced the majority of the lithics are both interpreted as decomposed turfs that originated as collapsed wall material. It is probable that the turfs used to construct the walls were taken from the adjacent ground and this contained prehistoric lithics. This suggests that the minor Bronze Age deposits encountered beneath the post-medieval shelters are only part of a more extensive occupation site that has been disturbed by turf cutting.

\subsubsection{Reuse and expansion over time}

The radiocarbon dates from this site show a similar pattern of use as that of Site $6 \mathrm{~A}$. The early occupation phase was dated to the Middle Bronze Age, roughly contemporary with the early phase at Site $6 \mathrm{~A}$, followed by a gap of over 2000 years before activity again resumed in the medieval period. The direct evidence for the Bronze Age phase was limited to two areas of charcoal-rich sediment with no associated structures and only one struck quartz flake. However, there is indirect evidence for more substantial Bronze Age activity in the immediate vicinity through the lithics that were retrieved from the turf walls of later structures. It is assumed that the use of this site in the Bronze Age was determined by the shelter provided by the rock face, as it clearly was in the later phases. However, it may also be noted that the sea-level displacement curve for Arisaig (Shennan et al. 1995) indicates that the site was close to the sea shore at the time, overlooking a large shallow inlet of brackish water that later evolved into the Mointeach Mhór. Proximity to the bay with its natural resources - such as bird life, fish and shellfish - may have been another important location factor although there is no direct evidence for this in the archaeological record.

The lack of objects associated with the stack of late medieval and post-medieval structures supports the suggestion that the site was not part of a permanent settlement but is likely to have been used as a temporary shelter, possibly by people herding livestock. It may be contemporary with the two other small structures nearby, although these were not investigated and remain undated. The cultivation rigs in this area are assumed to be of 19th century date, as they are elsewhere along the road line.

\subsection{Rectangular turf structure: Site 10 (NM 6583 8835)}

\subsubsection{Survey}

The structure was located $420 \mathrm{~m}$ to the south of Site 8 on a low sand ridge at the western edge of Mointeach Mhór, probably a fossil beach ridge. It measured $3 \mathrm{~m}$ by $7.5 \mathrm{~m}$ internally within turf banks $1.2-1.8 \mathrm{~m}$ wide and up to $0.6 \mathrm{~m}$ high. It was aligned north to south with an entrance to the east. A square hollow $5 \mathrm{~m}$ by $5 \mathrm{~m}$ located $5 \mathrm{~m}$ to the north could possibly have been 
created when the turfs were cut for the construction of the building. The building was located on the west side of a large rectangular area of improved ground, $75 \mathrm{~m}$ by $200 \mathrm{~m}$, depicted on the first edition OS map surveyed in 1873. The CFA survey identified a second structure just to the east, but this was not seen during the subsequent fieldwork. However, a second rectangular turf structure $4 \mathrm{~m}$ by $6 \mathrm{~m}$ was recorded $70 \mathrm{~m}$ to the south.

\subsubsection{Evaluation}

A trench was cut across the south wall of the building, exposing a well-defined turf wall with the individual turfs still visible. The wall was $1 \mathrm{~m}$ wide and $0.45 \mathrm{~m}$ high. A possible occupation layer of white sand with dark patches was recorded inside the building, above the natural white sand. Six pottery fragments were retrieved from the floor level of the building. These were identified as fragments of fine earthenware and a stoneware bottle. They were dated to the late 19th century or, more probably, the early 20 th century. The site was interpreted as a late 19th-century turf building and, as a result, no further investigation was carried out.

\subsection{Township: Site 15 (centred on NM 658 878)}

\subsubsection{Survey}

This site comprised eight buildings with associated banks and cultivation remains situated to the west of Kinloid overlooking Mointeach Mhór. It formed part of a now-abandoned settlement depicted on the first edition OS map and named Achraig. Three of the structures were depicted on the map as roofed buildings. The other five buildings were not mapped. Four buildings were selected for evaluation to test for the presence of earlier (pre-19th century) settlement on the site.

\subsubsection{Evaluation}

Four buildings were selected for evaluation. In order to increase the possibility of identifying earlier components of the township, three of the buildings were examples of those not depicted on the first edition OS map and were believed to pre-date the map. A trench was cut across the walls of each of the structures to evaluate the date and nature of these sites. Two of the four structures were defined by turf and stone walls, the other two were built with dry-stone walls. The structures were interpreted as the remains of small heavily robbed enclosures and buildings. The finds assemblages from the sites were of early to mid 19th-century date. No evidence was obtained for settlement pre-dating the 19th century.

\subsubsection{Watching brief}

The area was closely watched during the topsoil stripping prior to the construction of the road to record any early remains of the township not visible on the surface. A number of 19th-century glass and ceramic finds were recovered from the topsoil and two features were recorded: a large field bank seen during survey and an oval clearance cairn. The field bank comprised a single homogeneous deposit of earth with no evidence for a prolonged or complex history. Two small pits were also recorded, 0.3 and $0.5 \mathrm{~m}$ in diameter and $0.1-0.2 \mathrm{~m}$ deep. The larger and shallower pit contained a primary fill with fragments of charcoal and burnt bone. The bone fragments were too small for identification and none of the pits contained any datable artefacts. The watching brief did not yield any evidence of an earlier phase of the township pre-dating the 19th century.

\subsection{Rectangular building: Site 26 (NM 65998693 )}

\subsubsection{Survey}

This structure was located on the south-west side of a small knoll some $500 \mathrm{~m}$ to the north of Arisaig village. It comprised the footings of a rectangular building aligned north-east to south-west that measured $3 \mathrm{~m}$ by $7.7 \mathrm{~m}$ internally, with a rectangular structure immediately to the north-east, possibly a lean-to structure built up against the east gable of the building. The building was not recorded on any maps so it was selected for evaluation to determine its nature and date.

\subsubsection{Evaluation}

Two trenches $1 \mathrm{~m}$ by $4 \mathrm{~m}$ were excavated within the site. One trench was located across the interior of the building, with the other trench cutting across the north-east wall and into the smaller structure.

The walls were dry-stone random rubble construction with a brown sand and gravel floor in the larger building and a roughly paved floor in the structure to the east. A couple of roof slate fragments were retrieved from the building but, unlike Site 15, the structure produced no glass or ceramic fragments. The site was believed to be an isolated early 19th-century building. It is not depicted on the first edition OS map and is therefore likely to have been demolished prior to 1870 .

\subsection{Kerb cairn: Site 41 (NM 6634 8651)}

The cairn was located during walkover survey along the road corridor carried out early in 2000 by the 


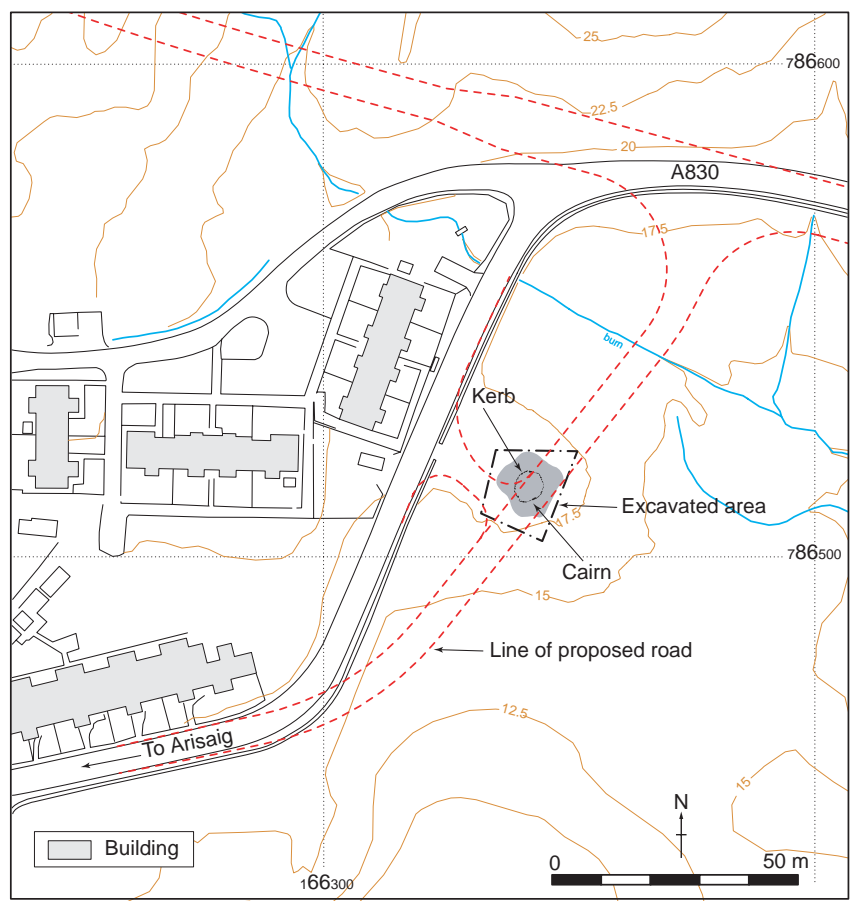

Illus 13 Contour map showing location of Site 41
CFA. It was located $20 \mathrm{~m}$ east of the old A830 as it entered Arisaig from the east (Illus 13). The feature appeared as a grassy mound $12 \mathrm{~m}$ in diameter and $1 \mathrm{~m}$ high. The nature of the monument was clarified at the time through a small hand-excavated trench that confirmed that the mound comprised small stones. The cairn was believed to be a funerary monument as the location made it less likely to be made from field clearance. This interpretation was confirmed during an evaluation carried out by Headland Archaeology at the end of 2000, which identified the remains of a robbed out cist in the centre of the structure and a boulder kerb on the north side of the cairn. As a result of the evaluation results, a programme of full excavation was carried out during July and August 2001.

\subsubsection{Excavation}

A trench measuring $30 \mathrm{~m}$ by $30 \mathrm{~m}$ was excavated, centred on the cairn. No features or deposits of archaeological significance were identified in the area around the cairn. Bedrock was found to lie directly below topsoil in many places and the cairn itself was constructed on top of an outcrop of bedrock (Illus 14).

The first stage of construction comprised a $6 \mathrm{~m}$ diameter kerb cairn (Illus 15). The kerb was built

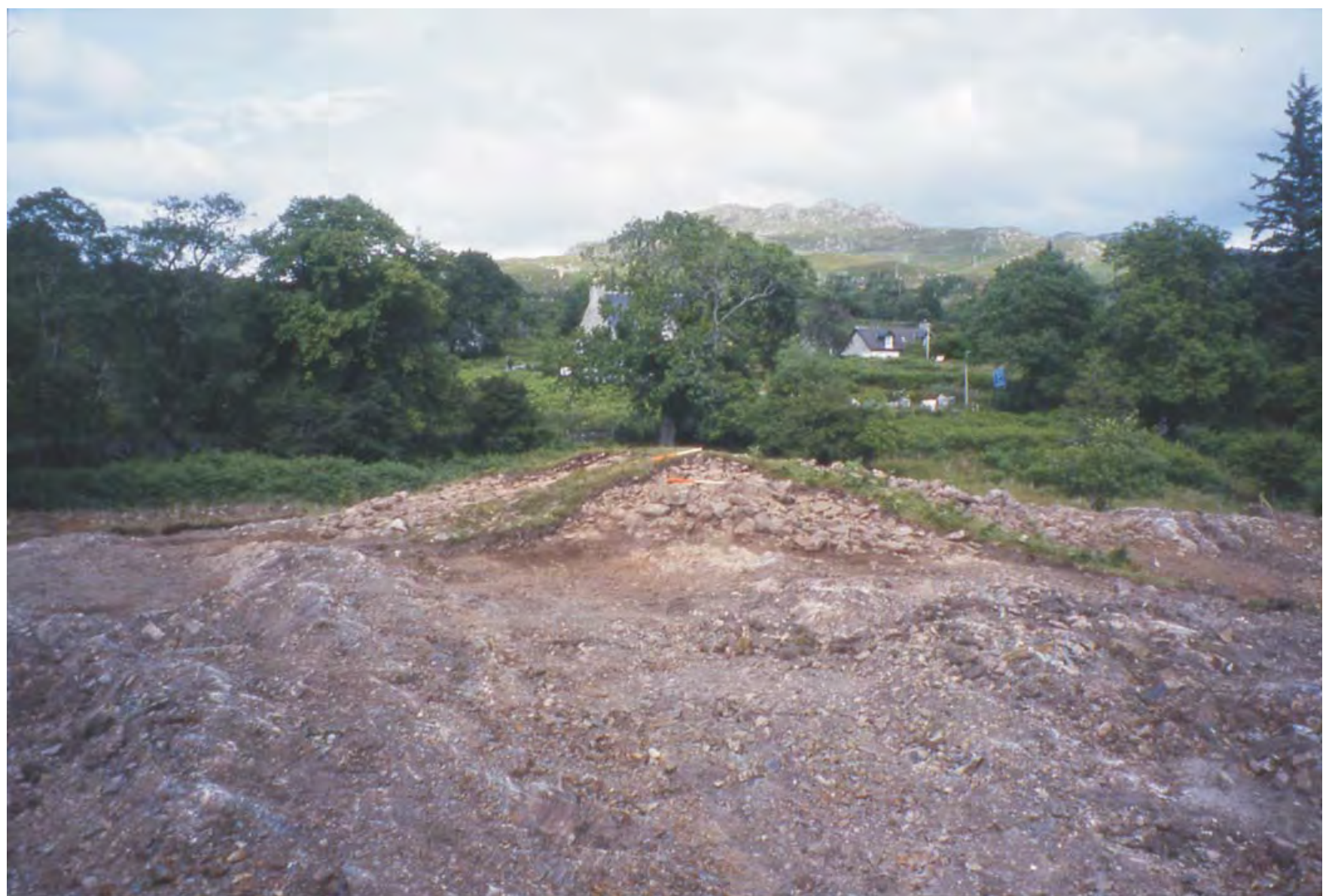

Illus 14 Site 41: view of cairn after turf removal, from the south-west 


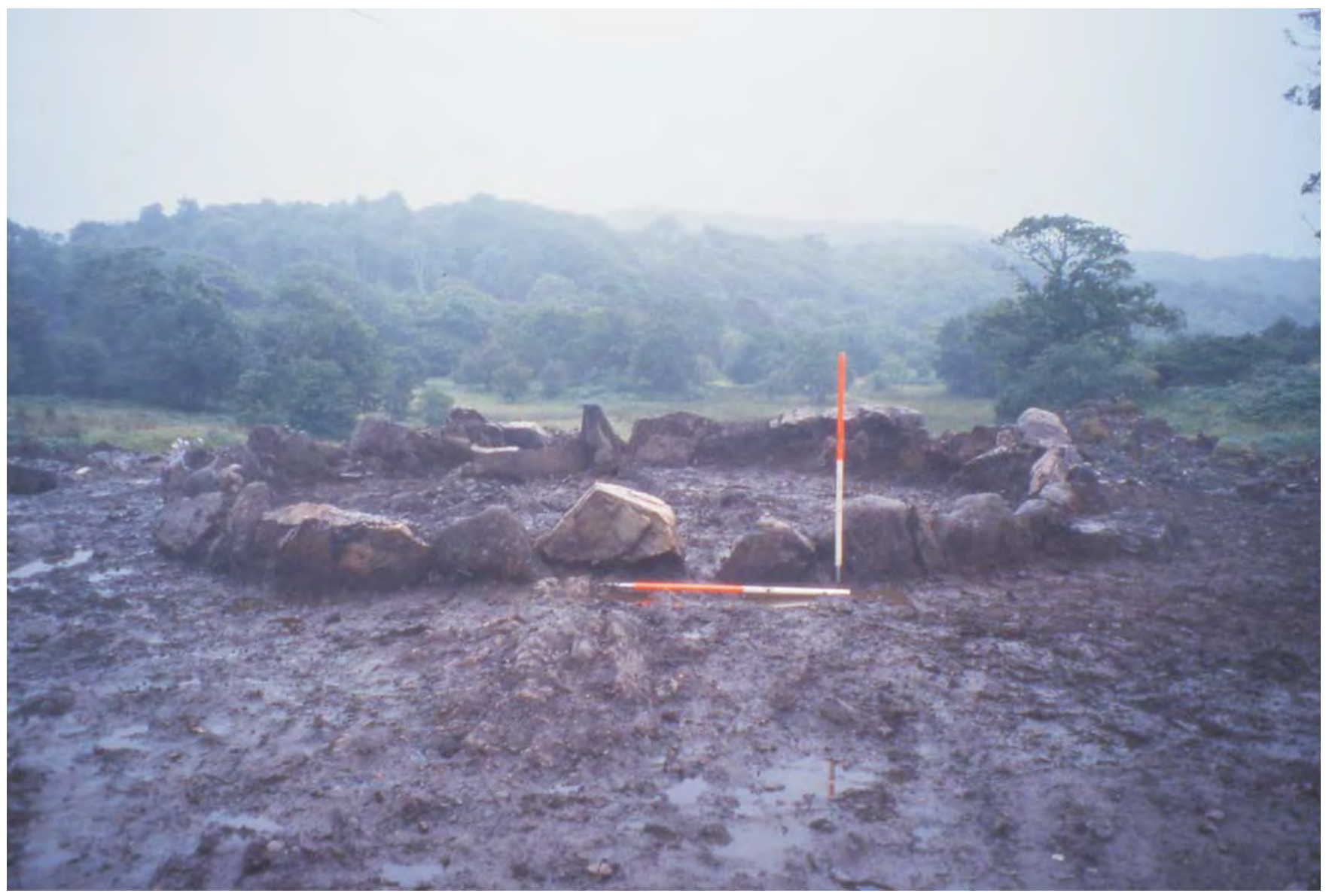

Illus 15 Site 41: ring of kerb-stones, viewed from the north

from large upright boulders supported on the inside by a layer of similarly large stones (context 4110). The remains of the robbed out cist (context 4105), identified during the evaluation, were fully exposed and found to measure approximately $1 \mathrm{~m}$ in length and $0.45 \mathrm{~m}$ in width, although this may not represent the original size of the feature given that only two sides survived. No human remains or artefacts were retrieved from within it. The cist was supported by the basal layer of stones (4110) and was thought to be contemporary with the erection of the kerb (Illus 16).

A small deposit of cremated human bone was identified $3 \mathrm{~m}$ to the north of the cist. It was recovered in an area measuring some $0.5 \mathrm{~m}$ by $0.5 \mathrm{~m}$, within the basal layer of cairn stones (4110). The bones had not been interred in any cist-like structure but it is possible that they were deposited in an organic container that has totally decayed. The bone appears to have been deposited at the time of the cairn's construction although it is impossible to confirm that stones were not moved to allow its insertion at a later date. Analysis of the remains suggested that they were from one adult individual (D Henderson, pers comm). A sample of the bones was dated by radiocarbon (SUERC-2451/GU-11904) and returned an Early Bronze Age date between 2140 and 1910 BC (Table 3 and Illus 17).
Above the basal layer of cairn stones was a layer of large voided stones (context 4102) within dark red-brown silty sand. These were all located on the interior of the kerb. Around the exterior of the kerb, natural subsoil was overlain by a layer of stones (context 4109) within dark brown silty sand, which formed a concentric band around the kerb, roughly $2.5 \mathrm{~m}$ in width. This layer abutted the boulder kerb and had clearly been deposited after its construction.

The whole cairn was overlain by a layer of smaller stones (context 4101) in a matrix of light yellowbrown silty sand (Illus 18), forming a significant mound measuring some $12 \mathrm{~m}$ in diameter and at least $1 \mathrm{~m}$ in height (Illus 19). Fifteen small sherds and crumbs of prehistoric pottery were recovered from one location in the south-east quadrant. There are traces of comb-impressed decoration on several sherds and they have tentatively been identified as part of a Beaker (A MacSween, pers comm). In the north-west quadrant of the cairn, a spread of charcoal (context 4103) was identified overlying layer 4101 . It measured some $1.0 \mathrm{~m}$ by $0.6 \mathrm{~m}$ and was only $7 \mathrm{~mm}$ deep. Its origin was unclear and no small finds were retrieved from the feature. A sample of the charcoal was dated by radiocarbon (SUERC-2452/GU-11905) to the period between $50 \mathrm{BC}$ and $\mathrm{AD} 140$ (Table 3 and Illus 17). 


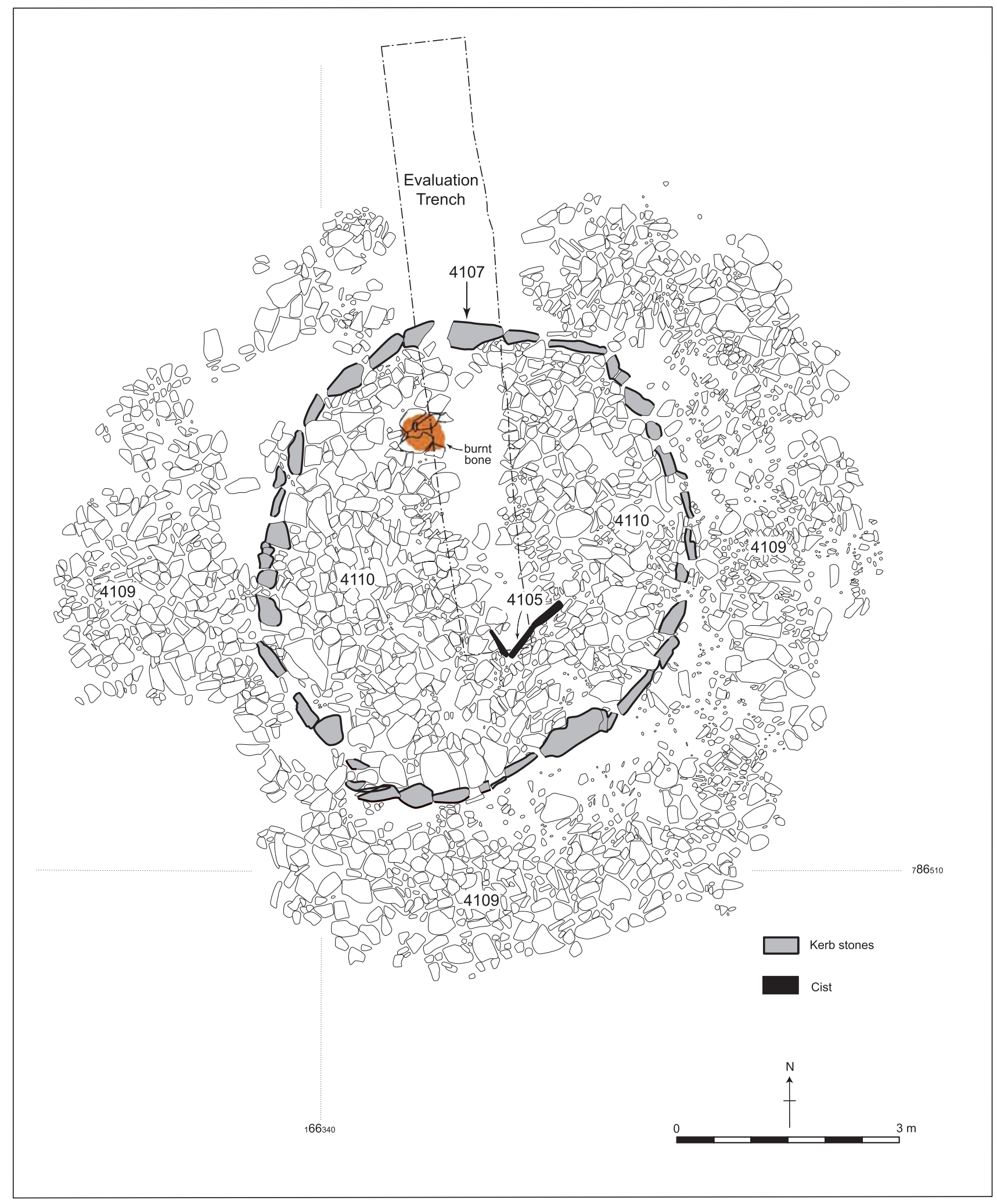

Illus 16 Site 41: plan of kerb and robbed out cist with basal layer of stones 


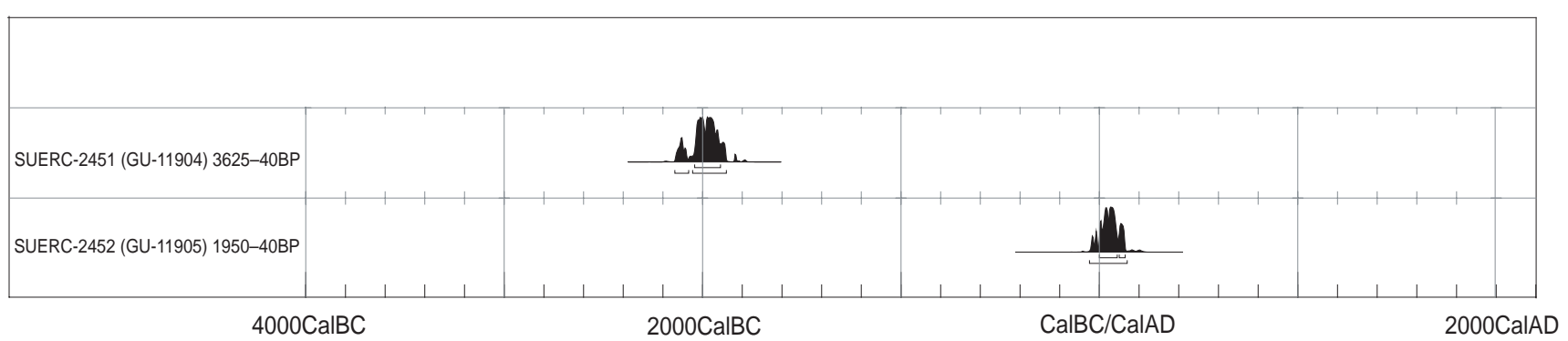

Illus 17 Calibrated radiocarbon determinations from Site 41

Table 3 Radiocarbon determinations of samples from Site 41

\begin{tabular}{|c|c|c|c|c|c|c|}
\hline Lab code & Context & Material & Lab age BP & $\delta \mathbf{C 1 3}$ & 1 sigma cal & 2 sigma cal \\
\hline $\begin{array}{l}\text { SUERC-2451 } \\
(\text { GU-11904) }\end{array}$ & Find 2 & $\begin{array}{l}\text { Burnt human } \\
\text { bone }\end{array}$ & $3625 \pm 40$ & $-26.1 \%$ & $2040-1910$ вС & $\begin{array}{l}2140-2070 \text { вС }(12.7 \%) \\
2050-1880 \text { вС }(82.7 \%)\end{array}$ \\
\hline $\begin{array}{l}\text { SUERC-2452 } \\
\text { (GU-11905) }\end{array}$ & 4103 & Alnus & $1950 \pm 40$ & $-26.8 \%$ & $\begin{array}{l}\mathrm{AD} 1-90(58.5 \%) \\
\mathrm{AD} 100-30(9.7 \%)\end{array}$ & $50 \mathrm{BC}$ to $\mathrm{AD} 140$ \\
\hline
\end{tabular}

The centre of the cairn was dug into at some time after it had reached its final form. This left a depression measuring $4 \mathrm{~m}$ in diameter and $0.3 \mathrm{~m}$ deep at the present-day ground surface. Whenever this robbing occurred, the result was partial destruction of the cist and complete removal of its contents.

\subsubsection{History and use}

This monument is a new example of a small Bronze Age kerb cairn, a type of funerary monument now familiar in the west of Scotland (Lynch \& Ritchie 1977). There are three other unexcavated cairns in the Arisaig area that may be similar monuments (Illus 2). The nearest cairn lies some $200 \mathrm{~m}$ to the south: it is a kerb cairn of similar dimensions, $15 \mathrm{~m}$ in diameter and $1 \mathrm{~m}$ high, but it is badly robbed (NMRS no NM68NE 7). One kilometer to the south lies a much larger cairn, $30 \mathrm{~m}$ in diameter and $1.2 \mathrm{~m}$ high (NMRS no NM68NE 6). The third cairn is situated $2.2 \mathrm{~km}$ to the south (NMRS no NM68SE 5); it measures only $5 \mathrm{~m}$ in diameter and is $0.5 \mathrm{~m}$ high so may not be a funerary cairn like the others.

The recorded structure and stratigraphy of the cairn allows for more than one interpretation of the constructional sequence and history of the cairn. The cist, although not central to the kerb, is apparently a primary feature. The band of stones outside the kerb was clearly placed there after the kerb was built but it does not totally obscure the kerb. It could therefore either be an original element of the cairn or an addition. The upper layer of smaller stones is assumed to be an addition and may represent the gradual accumulation of field clearance stones rather than a formal element of the funerary cairn. The interpretation is supported by the smaller size of the stones and the irregular extent of the deposit.

The dating of the original construction of the cairn is dependent on the interpretation of the small cache of cremated human bone within the lowest level of the kerb cairn. If the bone is assumed to have been deposited during the original construction (and there is no evidence to the contrary) and does not represent a token deposit of the curated remains of an ancestor, it can be used to date construction to around 2000 BC. This is perfectly acceptable when compared with dates from similar monuments (Lynch \& Ritchie 1977). The presence of a few small fragments of probable Beaker in a stratigraphically late context on the edge of the cairn raises the possibility that the monument is in fact significantly earlier. If the pottery represents the fragmentary remains of the grave goods from the disturbed cist, it would suggest a construction date several centuries earlier in the third millennium BC. In this case the cache of human bone would have been a secondary burial into the kerb cairn. It is equally probable that the fragments of probable Beaker are derived from another source - possibly another burial nearby - and they were disturbed and unintentionally deposited on the cairn during later field clearance. In this context, it is interesting to note the Iron Age date obtained from the patch of charcoal on the surface of the cairn. This suggests that the formation of the cairn, including the deposition of field stones, was essentially complete by this time and it may be used as evidence for sustained cultivation of the land around the cairn during later prehistory. The land surrounding the cairn remained in cultivation until the recent past and is now improved pasture. 


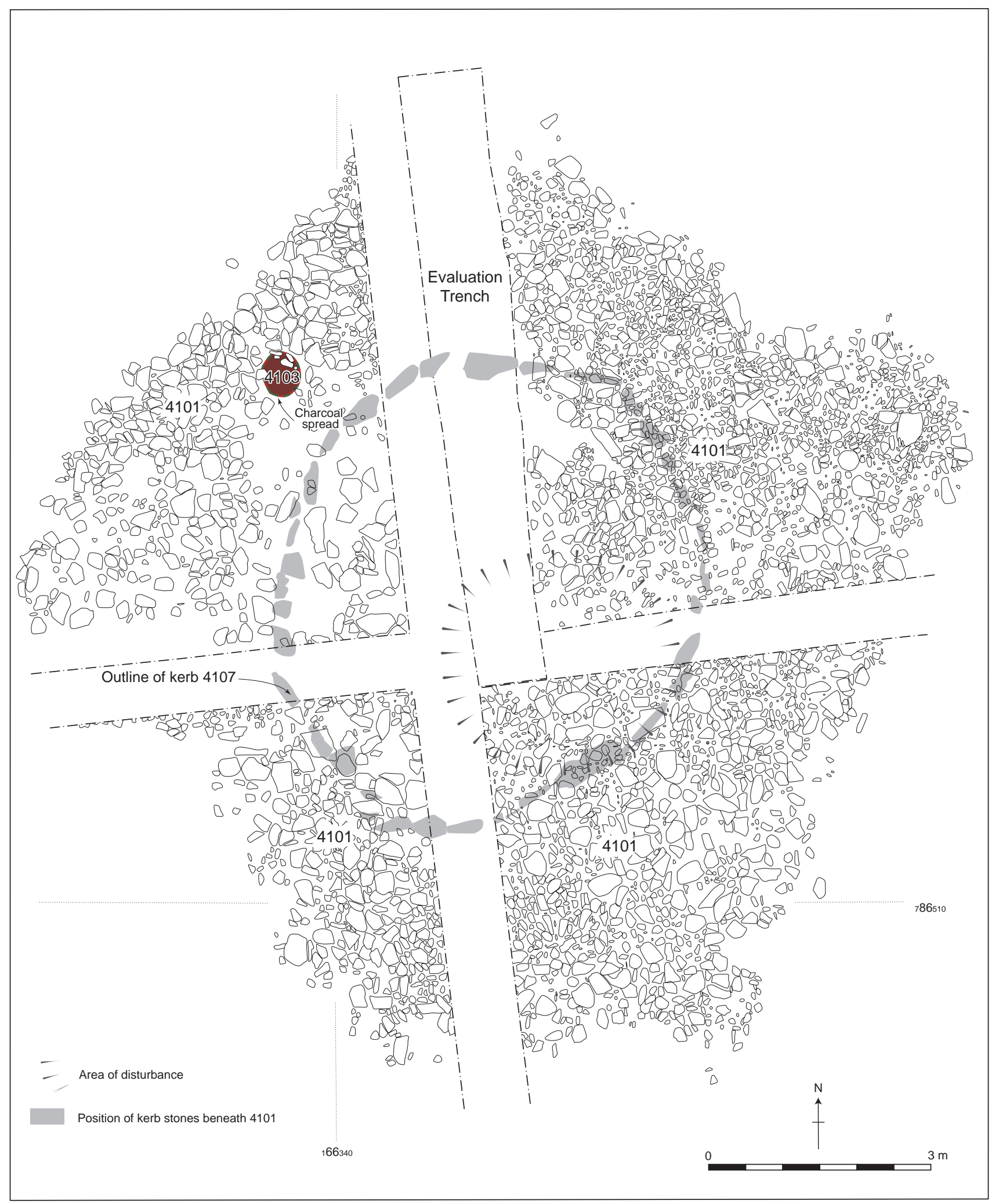

Illus 18 Site 41: cairn after removal of topsoil 
Profile 1

$\stackrel{N}{x}$

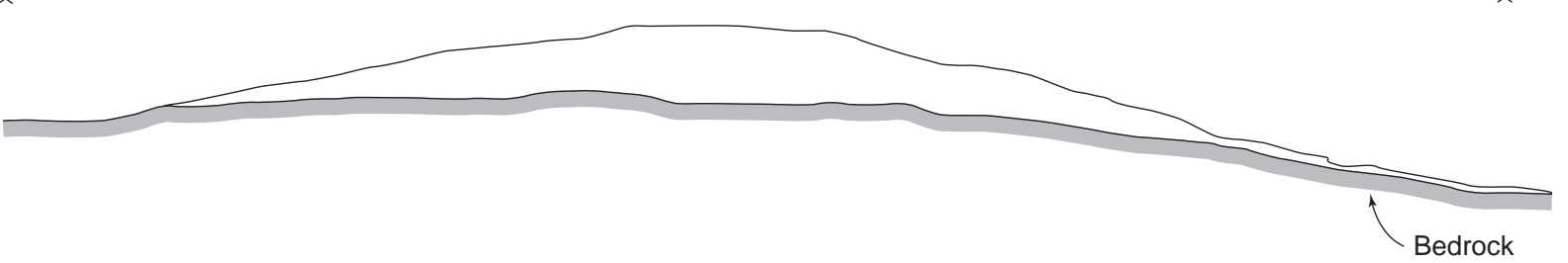

Profile 2

昙

W

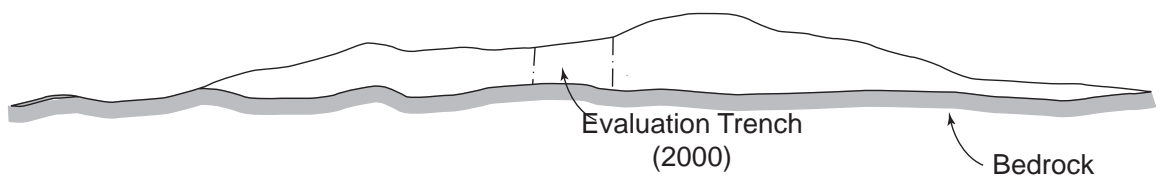

Evaluation trench
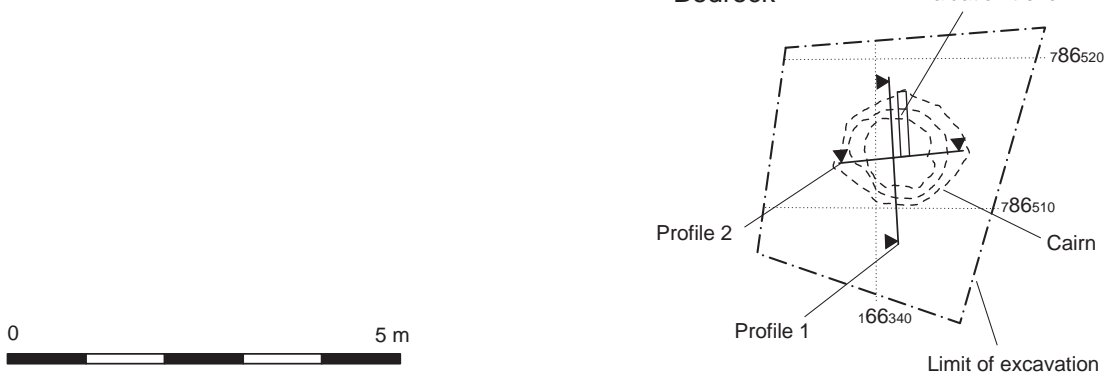

Limit of excavation

Illus 19 Site 41: sections of the kerb cairn from (a) the north (Profile 1) and (b) the east (Profile 2) 


\section{Vegetation History}

The archaeological programme was supported by palaeoenvironmental studies. A deep peat basin was identified during the initial archaeological survey of the roadline at Allt Dail an Dubh-asaidh (Illus 2). A peat core was extracted from this site and analysed to provide a high-resolution record (both spatial and temporal) of the vegetation of that area. A summary of the results and full consideration of their implications for the archaeology of Arisaig is included in this report. For a more detailed consideration of the data (see Section 9 - Palynological Analysis)

\subsection{Peat core from Allt Dail an Dubh-asaidh}

A $6.67 \mathrm{~m}$ peat core was extracted and analysed for pollen and charcoal at intervals of $4 \mathrm{~cm}$, giving a total of 160 samples. Radiocarbon dating of pollen zones throughout the core has indicated a date range from $8000 \mathrm{BC}$ to the present day for the sediments. Analysis of the core at a resolution of approximately 50 years has illustrated a continuous Holocene vegetation sequence from open water prior to $8000 \mathrm{BC}$ up to the present-day mix of acid heath and birchhazel-oak woodland.

The pollen derives from both local vegetation (that is, within the small basin that the peat was accumulating) and from extra-local and regional vegetation. The pollen sequence can be divided into six zones that primarily reflect changes in the local vegetation as the original lochan gradually filled with peat (summarized in Table 4). Changes in the extra-local and regional pollen are much less clear-cut and must be isolated from the more obvious local changes in order to identify change in the wider landscape.

Within the basin, the original open-water lochan was progressively colonized by willow carr which, after an open marsh phase from $6100 \mathrm{BC}$ with grasses, sedges and some fen species, was in turn colonized by alder carr at about 4950 BC. Alder declined at about $3200 \mathrm{BC}$ to give way to a lingdominated heath; this was replaced by a bog myrtle heath about $400 \mathrm{BC}$, which persists to the present day. The open marsh phase from 6100 to $4950 \mathrm{BC}$ coincides with increased charcoal concentrations. This is likely (at least in part) to be a result of the temporary widening of the woodland canopy, also reflected in increased concentrations of airborne pollen, like pine. However, the presence of large charcoal particles $(>75 \mu \mathrm{m})$, between 524 and $544 \mathrm{~cm}$ in the core (dating roughly to $5900-5550 \mathrm{BC}$ ) is likely to be the product of burning close to the core site. The cause of this burning cannot be determined from the pollen core but may reflect activity by Mesolithic people in the immediate area.

In the wider landscape, the vegetation was birchhazel-oak woodland with some pine and elm throughout the early prehistoric period. High percentages for tree pollen, alongside continued but low levels of disturbance, suggest some kind of woodland use between 3200 and 400 BC. Woodland cover is maintained until $3200 \mathrm{BC}$ when it starts to decline gradually, associated with elevated levels of charcoal. Large charcoal particles $(>75 \mu \mathrm{m})$ probably reflect burning events close to the pollen core site between 236 and $256 \mathrm{~cm}$ (roughly 1350-1520 BC). From 3200 вс there is evidence for low levels of vegetation disturbance relating to human activity with ruderal pollen types (like ribwort plantain, nettle and goosefoot) indicating disturbance, consistently recorded. The sequence is interpreted as reflecting extensive grazing impacts which, particularly from about $600 \mathrm{BC}$, maintained a regionally open vegetation with discrete pockets of woodland. After $600 \mathrm{BC}$, while the decline in woodland pollen continues, along with sustained curves for ruderal pollen types, while charcoal frequencies decline. This suggests sustained but low levels of disturbance with human activity throughout the area but with less impact

Table 4 Pollen zones, identifying main local and extra-local and regional vegetation types

\begin{tabular}{|c|c|c|c|c|}
\hline Zone & $\begin{array}{l}\text { Depth } \\
\text { (cm) }\end{array}$ & $\begin{array}{l}\text { Calibrated date } \\
\text { (approx) }\end{array}$ & $\begin{array}{l}\text { Local (on site) } \\
\text { vegetation }\end{array}$ & $\begin{array}{l}\text { Extra-local and regional } \\
\text { vegetation }\end{array}$ \\
\hline $1 \mathrm{~F}$ & $0-176$ & $400 \mathrm{BC}$ to present day & Sedge-ling-bog myrtle heath & Birch-hazel-oak woodland \\
\hline $1 \mathrm{E}$ & $176-368$ & $3200-400$ вС & Ling heath & Birch-hazel-oak woodland \\
\hline $1 \mathrm{D}$ & $368-480$ & $4950-3200$ вС & Alder carr & $\begin{array}{l}\text { Birch-hazel-oak woodland with } \\
\text { elm and pine }\end{array}$ \\
\hline $1 \mathrm{C}$ & $480-544$ & $6100-4950$ вС & $\begin{array}{l}\text { Open marsh with sedges and } \\
\text { grasses }\end{array}$ & $\begin{array}{l}\text { Birch-hazel-oak woodland with } \\
\text { elm and pine }\end{array}$ \\
\hline $1 \mathrm{~B}$ & $544-640$ & $8000-6100$ вС & $\begin{array}{l}\text { Willow carr with sedges and } \\
\text { grasses }\end{array}$ & $\begin{array}{l}\text { Birch-hazel-elm woodland with } \\
\text { pine }\end{array}$ \\
\hline $1 \mathrm{~A}$ & 640-base (666) & Before 8000 BC & Open water & Willow carr \\
\hline
\end{tabular}


from burning activity. The sustained disturbance that causes continued declines in tree pollen and an increase in open vegetation is likely to be livestock grazing.

\subsection{Other evidence for vegetation history of the Arisaig area}

The results from Allt Dail an Dubh-asaidh provide detailed data on only one small part of the Arisaig landscape. Fortunately, there are pollen diagrams available from four other locations in or very close to Arisaig that can be used to assess variations in landscape history across this area (Illus 2). Of the four pollen diagrams available, all of them are dated, although some are incomplete sequences. There is a complete Holocene sequence from Lochan Doilead in North Morar (Williams 1977), partial diagrams from the Mointeach Mhór and Loch nan Eala in Arisaig (Shennan et al. 1994; Shennan et al. 1995) and a later Holocene sequence from Polnish, east of Borrodale (Clarke 2000). The changes in tree pollen percentages from Lochan Doilead, Allt Dail an Dubh-asaidh and Polnish are summarized in Illus 20.

Williams demonstrates an elm decline at $3550 \mathrm{BC}$, marking the start of woodland decline in North Morar, which is steady and progressive from here to the top of the diagram (Williams 1977). Later, at $2150 \mathrm{BC}$, the start of continuous curves for ruderal pollen types reflects continuous, although low, levels of disturbance accompanied by more marked woodland decline. Woodland recovers at about 500 BC and fluctuates from the Iron Age to the present day, although there is an overall sustained decline. It is only at about $\mathrm{AD} 600$ that heath pollen types start to increase, most notably with the start of the increase in ling (Calluna vulgaris) pollen. Overall, the history of gradual but progressive woodland decline at Lochen Doilead from $3550 \mathrm{BC}$ is very similar to that obtained from Allt Dail an Dubh-asaidh.

Just to the south of the pollen site at Allt Dail an
Dubh-asaidh, pollen and diatom records were used to look at sea-level change in the area (Shennan et al. 1995). Entire pollen sequences were not analysed and most sections from Mointeach Mhór dated to $1250 \mathrm{BC}$ to just after $780 \mathrm{BC}$ (Shennan et al. 1995). This period is characterized by a sharp decline in woodland pollen at $780 \mathrm{BC}$ with a slight increase in ribwort plantain, indicating levels of disturbance with grasses and ling. This, with similar evidence from Allt Dail an Dubh-asaidh, appears to reflect regional woodland decline between about 3200 and 650 BC. Pollen analyses from Loch nan Eala were also undertaken for information on sea-level changes. This core has ten stratigraphically distinct sections that were dated to between 10,500 and $7050 \mathrm{BC}$, and at $c 7150,5500,2520,2140,1930$ and 1730 BC. From about $2500 \mathrm{BC}$ at this site, ruderal pollens, including ribwort plantain, are present, accompanied by lower values for woodland pollen types. The core, again, seems to reflect the wider regional decline in woodland from about $2500 \mathrm{BC}$, although interpretation of the data in terms of vegetation history is difficult given the short and separate sections analysed. This is particularly unfortunate as Loch nan Eala lies within the potential 'core' settlement area of Arisaig and could contain evidence for a different landscape history over the past 5000 years.

Further to the east, a short core from a woodland hollow has been dated and analysed (Clarke 2000) and provides a vegetation record from about $1850 \mathrm{BC}$ to the present. Decline in woodland pollen is much less apparent in this core and this may reflect its location in an area of steep slopes that is wooded at present. High total tree pollen values are maintained for 2900 years from $1850 \mathrm{BC}$ but the proportion of birch and oak pollen varies, with an increase in birch possibly reflecting exploitation of oak during this period. Charcoal increases from about $\mathrm{AD} 1020$ to the top of the core and is likely to be reflecting increased human activity and burning. Increased grazing at the top of the sequence has also been inferred (Clarke 2000). 


\section{Occupation and Use of a Marginal Landscape}

\subsection{Core and periphery in Arisaig}

In the introduction to this paper it was suggested that the existing archaeological record for Arisaig supports the identification of a core area of permanent settlement from as early as the Bronze Age, surrounded by peripheral areas of less-intensively exploited land. The data collected in the course of the A830 investigations support this model, with relevant evidence coming both from site-specific archaeological studies and the landscape-scale palaeoenvironmental study.

The site-specific data are limited in terms of the number of sites but are clear-cut. The proposed core area yielded a Bronze Age kerb cairn, the third or fourth recorded example from this area, neatly reinforcing the restricted distribution of this site type. The later history of the kerb cairn includes modification and disturbance resulting from agriculture and other activities, reflecting the dynamic nature of the landscape within an area of permanent settlement. The pollen evidence reflects higher levels of disturbance and impact on the woodland vegetation from the Bronze Age (Illus 20) with patchy regeneration during the Iron Age and beyond. This is likely to be reflecting a change in land use in both the core and peripheral areas.

The peripheral area yielded examples of shieling huts and shelters (with dates spanning the medieval and post-medieval periods) and minor, but poorly understood, sites of Bronze Age date. It also contained long open spaces with no structural evidence for human activity (if the 19th-century sites are put to one side for the moment) and this emphasizes the highly selective use of the landscape. There is a strong contrast between empty areas and selected sites to which people have repeatedly returned. At Sites 3-6, there is a relatively sheltered and welldrained hill slope with running water that has been occupied over at least the 1000 years of the medieval and post-medieval periods as well as in the Bronze Age. At Site 8, there is a structure that was re-built on at least three occasions over a period of a few centuries, each time taking advantage of a vertical rock face to provide both shelter and one side of a lean-to type of shelter. Again, there is evidence that this precise spot was also occupied in the Bronze Age.

Repeated reuse of the same location presumably reflects the natural advantages of the site: for example water supply, drainage or shelter, which are all restricted commodities in this landscape. Most of the peripheral area is simply too rocky, too exposed or too wet to be occupied. Continuity of use may also reflect the influence of tradition where, once established, a site acquires strong social ties that ensure people keep returning to it despite other options being available. The land surrounding Sites 3-6 must be a candidate for a traditional shieling ground where these social ties operated. The repeated reuse of a few preferred sites has a major influence on archaeological visibility. Contrary to what might be expected in a landscape that has experienced low-intensity, extensive human land-use, archaeological sites are likely to be disturbed and obscured as sites are repeatedly reused. Effectively, they are isolated islands of highly intensive land-use with only the most recent structures visible on the surface. However, both the lack of any evidence in the archaeological record for Iron Age activity and the apparent change in woodland cover and disturbance levels in the pollen record perhaps reflect a cultural discontinuity at this time. Human activity is evident, but seems to have moved from the favoured Bronze Age sites in the peripheral areas, and was having an irregular impact on the woodland vegetation. Activities in the core area seem to have been modifying Bronze Age land-use practices, moving from burial to cultivation. Later in medieval times, the peripheral Bronze Age sites were again adopted. The pollen record reflects gradually intensifying land-use, resulting in an overall loss of woodland with irregular phases of regeneration during this time.

\subsection{Site-based and landscape-scale evidence for human impact}

The concentration of the site-based archaeological evidence into a few preferred locations in the peripheral area might give the impression that human impact was also restricted in its extent. But this is to confuse human impact with visible archaeological 'sites'; the key human impact in the peripheral areas has been the extensive modification of vegetation and, indirectly, of soils caused by the felling of trees and grazing of livestock. The rare archaeological sites are therefore of little value in gauging the nature and degree of human impact. In the present project there is no excavated evidence for human activity in the peripheral area before the Middle Bronze Age or for 2000 years before the medieval period, yet the pollen record from Allt Dail an Dubh-asaidh documented progressive removal of woodland from the late Neolithic period through to the present day without any significant reversals in this process. In fact, in the Arisaig area, no marked decline in woodland has ever taken place. This is unusual in Scotland and either reflects continuously low levels of occupation or use, or sustained 
Polnish

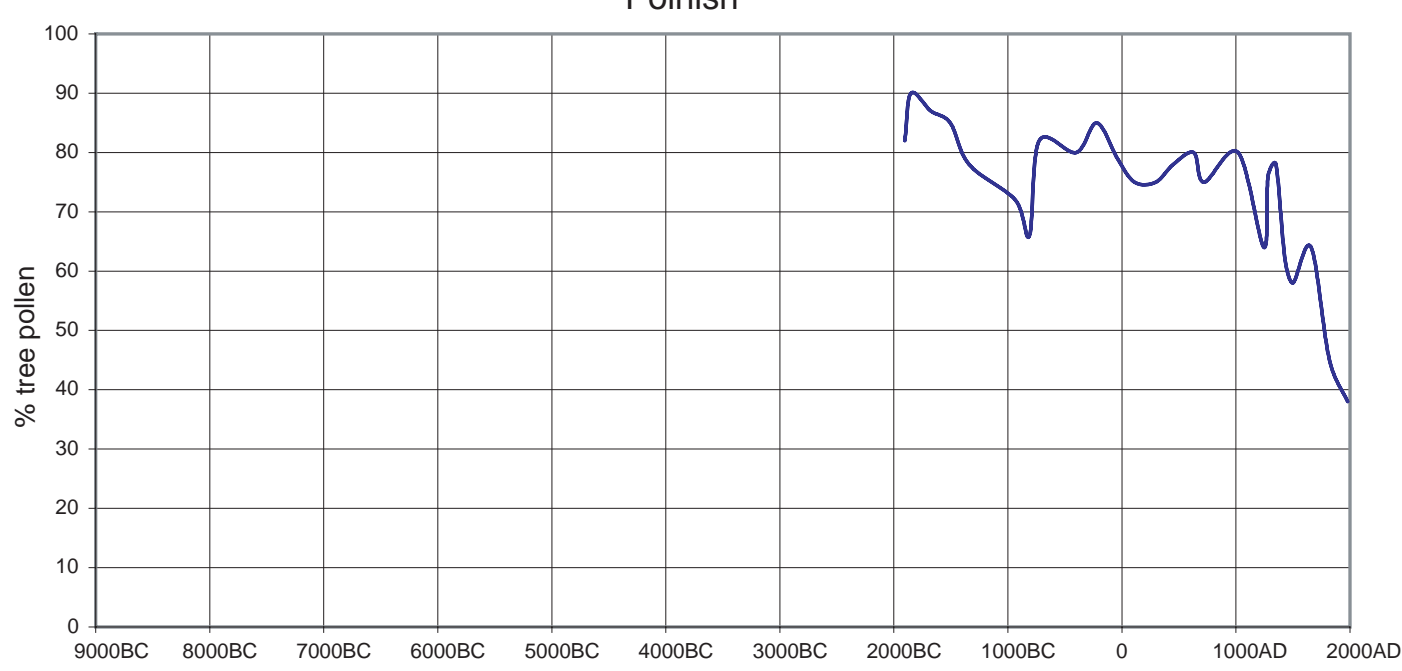

Lochan Doilead

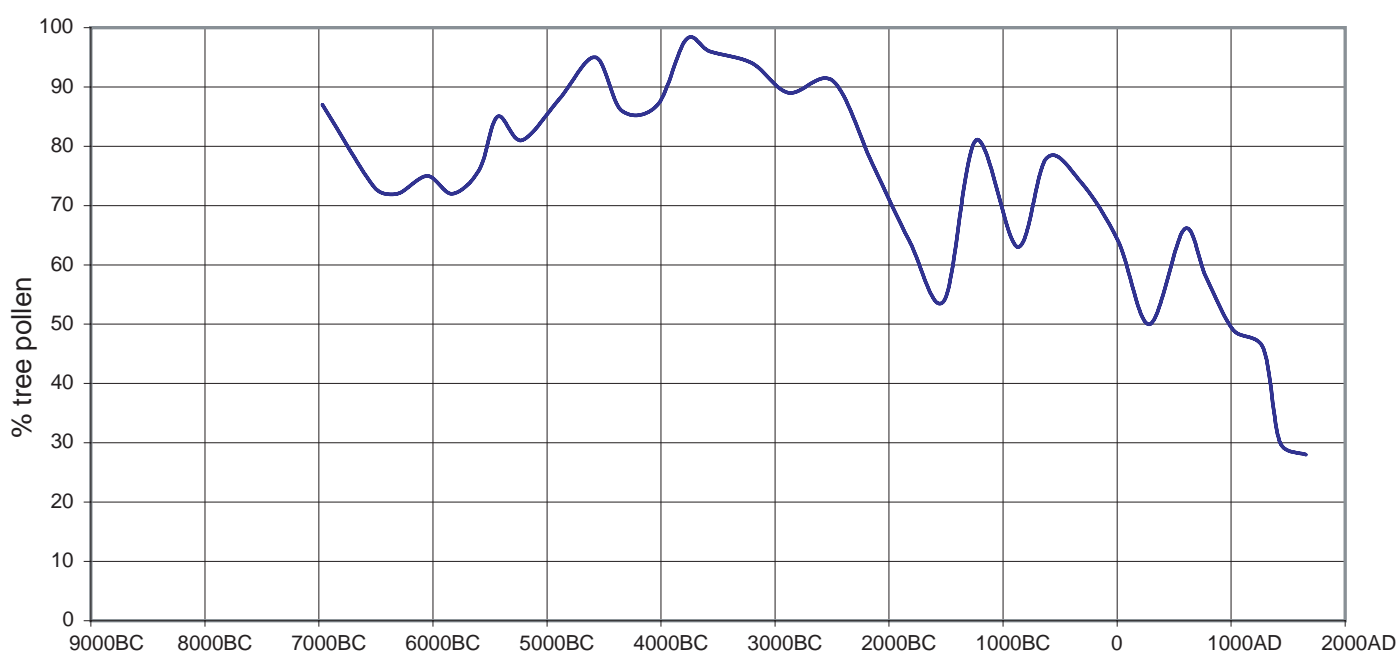

Allt Dail an Dudh-asaidh

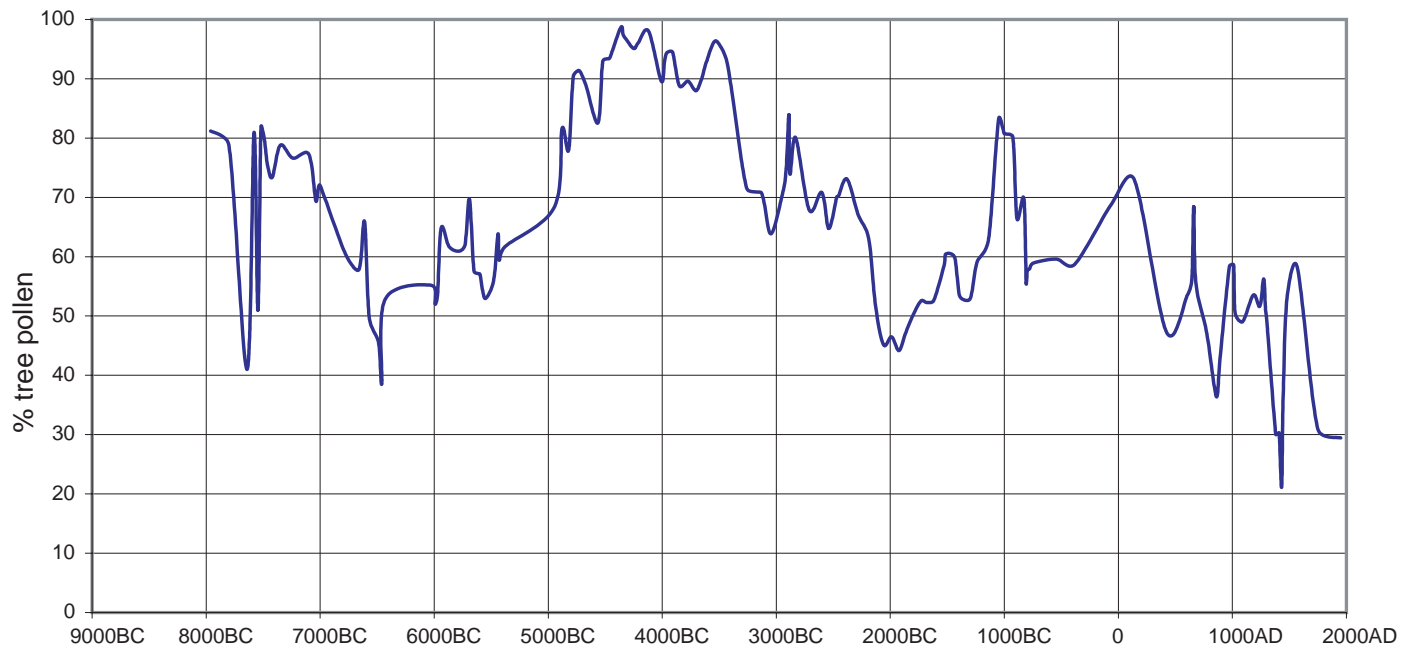

Illus 20 Changes in tree pollen percentages from Polnish, Lochan Doilead and Allt Dail an Dubh-asaidh 

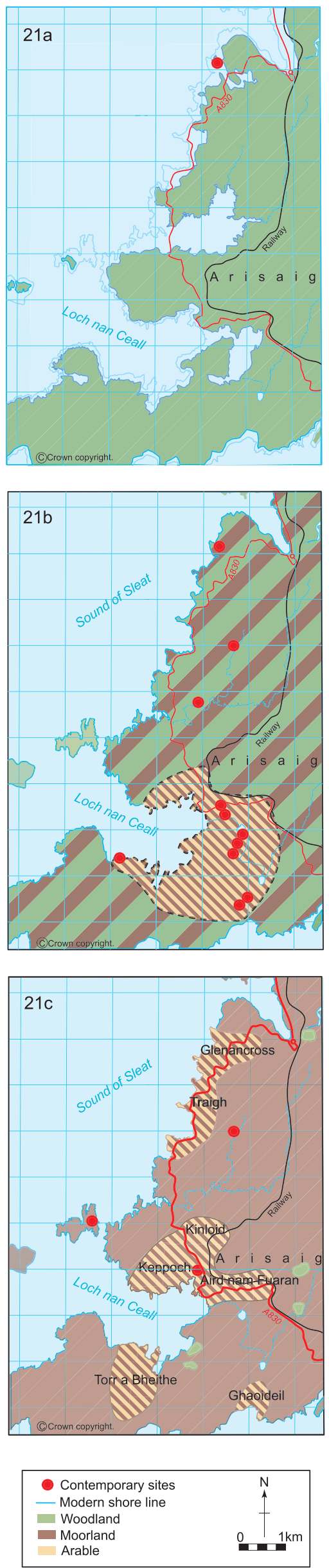

management of the woodland resource. This gradual decline in woodland, being punctuated with periods of removal and regeneration, could relate to the apparent change in land-use reflected in the archaeological record by a change from visible Bronze Age sites to currently invisible Iron Age ones.

It may be argued that the information obtained from the excavation of Sites 6 and 8 has contributed very little to an understanding of the nature of human activities in the past. For deposits where radiocarbon dates could be obtained, we can conclude that something happened at a particular time in the past, but the nature of that 'something' is impossible to define from the available evidence. The selective locations of these sites tells us about the ways in which people have 'read' and occupied their landscape but it is the peat-derived pollen and charcoal record that offers coherent data on the nature of human land-use and its changing impact through time. So, whilst it is satisfying as archaeologists to have detected the stacked sequences of occupation deposits in the shieling sites, we should recognize the limitations and high cost of excavation and be willing to invest sufficient resources in palaeoenvironmental approaches.

\subsection{Evolution of the Arisaig landscape}

The ultimate aim of this project has been to understand how the landscape of Arisaig evolved through time. The geographical limitations of the project were stated at the start of this paper and these can only be partially overcome through the use of data from other studies. Nevertheless, we believe that there is now sufficient data with which to propose a model of landscape evolution, if only to encourage critical testing by future researchers of its more speculative aspects. Three stages have been identified in the evolution of the landscape although they should probably be viewed as points along a continuum rather than persistent stages separated by relatively brief periods of transition (Illus 21a-c).

\subsubsection{Stage 1: Early prehistory (7500- 3550 BC), Illus 21 a}

We know from the published excavations at Kinloch on Rùm (Wickham-Jones 1990) and the more-recent work of the Scotland's First Settlers Project that the west coast of Scotland was populated by human communities from as early as 7500 BC. However, it

Illus 21 (left) Stages of landscape evolution near Arisaig: (a) early prehistory: 7500-3550 BC; (b) later prehistory: $3550 \mathrm{BC}$ to $\mathrm{AD}$ 500; (c) medieval and later period: $A D$ 500-1800 (from Ordnance Survey maps (C) Crown copyright) 
appears that there was no appreciable impact on the natural landscape of Arisaig throughout the Mesolithic and early Neolithic periods up until approximately $3550 \mathrm{BC}$, and Illus $21 \mathrm{a}$ shows a complete cover of woodland without attempting to plot the variation that must have existed in its species composition because of topographical variation. Human communities in this period exploited natural woodland resources without significantly modifying them and there is no evidence for a conventional MesolithicNeolithic transition from mobile hunter-gatherer to sedentary farmer. The pollen evidence indicates that the woodlands probably were used for grazing, if not as sources of wood, although there is no direct evidence for woodland management in the archaeological or palynological record. In Arisaig, this may reflect the fact that the areas that were later preferred as small core areas of settled farmland were largely underwater during this period, which coincides with the mid-Holocene sea-level maximum (Shennan et al. 1995; Shennan et al. 2002). The coastline shown in Illus 21a probably existed between 5900 and 3200 BC. Farming has subsequently developed on patches of raised beach and coastal shell sand that are freely draining, less rocky and less acidic than the rest of the landscape, which appears never to have been suitable for cultivation. So, early in the Neolithic period, agriculture may not have been a viable option, although pastoral farming probably was and herds of animals were grazing in and around the woodlands.

\subsubsection{Stage 2: Later prehistory (3550 BC to AD 500), Illus $21 b$}

Progressive differentiation of the landscape is detectable from $3550 \mathrm{BC}$ and it is assumed that the core farming area of Arisaig began to develop from this time, exploiting the limited areas of freely draining raised beach at the head of Loch nan Ceall although direct archaeological evidence is lacking until late in the third millennium BC. Other areas of land that emerged as relative sea level fell, for example the Mointeach Mhór, were too wet and rapidly developed into extensive salt marshes, through alder carr to ling-dominated bog.

There is no archaeological evidence as yet that the coastal shell sands were exploited. There has been no attempt to date these deposits and it is possible that the on-shore movement of sand did not occur until late in prehistory and therefore the development of what are now favourable soils for agriculture was also late. Pollen data show that woodland remained extensive throughout later prehistory. Fluctuations in woodland cover during the Late Bronze Age and into the Iron Age reflect periods of loss and regeneration. Regeneration in the Iron Age appears patchy and irregular, suggesting land-use changed with the resulting impact on the fragmenting woodlands. It is assumed that significant clearings were restricted to the core settlement area, where agriculture is more likely to have taken place. Woodland continued to be used for grazing.

\subsubsection{Stage 3: Medieval and later period (AD 500-1800), Illus 21c}

In this third stage of landscape evolution, three distinct types of land-use can be defined. The core settlement areas, with significant patches of cultivated land, have expanded along the sandy soils of the coast to include settlements such as Traigh and Glenancross (both settlements recorded in early rentals of Arisaig), perhaps reflecting increasing human populations. Woodland has become moreor-less restricted to defined areas (such as the pollen site at Polnish) where it is protected from grazing and managed for sustained production of timber. Remaining areas are essentially open heath and bog utilized for extensive livestock grazing.

\subsubsection{Postscript: The recent past (AD 1800- 1900)}

One final point should be made in this brief landscape history. The archaeological record in Arisaig is dominated by the remains of settlement and agriculture dating to the 19th century. Evaluation of selected sites during this project yielded artefact assemblages that suggest much of this settlement dates from a short period in the early to mid-19th century, and OS mapping from the 1870s shows that buildings were already in ruins and cultivation rigs abandoned by this date. The detailed history of this period can be explored in contemporary documents and this major task lay outside the resources and ambitions of the present project. Suffice to say that this brief period (perhaps no more than 50 years) appears as a major discontinuity in an archaeological record that otherwise emphasizes continuity of land-use and landscape development. Settlements were built where none was before; land was cultivated for the first and probably only time. The origins of this anomalous period no doubt lie in the catastrophic social and economic upheaval that overtook the western Highlands in the aftermath of the Highland Clearances: an event that finally broke the continuity of several millennia of landscape evolution in Arisaig.

Given the magnitude and high visibility of this event, as reflected in archaeological sites, it is important that we note the failure of it to register in the available pollen records for Arisaig. There are a number of possible explanations for this apparent anomaly. Pollen from cereal and potato crops does not disperse far so the short-lived fields were probably not close enough to the pollen sites reported here to register. Similarly, the construction of new settlements would not in itself register in the wider vegetation record. It might be assumed that a significant increase in population would lead to impacts on 
the surrounding landscape through increased demand for fuel (peat and wood) and for livestock grazing rights, but this is only an assumption. The absence of this effect may simply reflect the shortlived nature of the 19th-century events but it is also possible to interpret this as evidence that the pollen record is complacent in this regard. If a recent and well-documented episode of major social and economic change does not register in the pollen record we must remain cautious in our use of this source of information about past landscapes. Pollen only provides a proxy record of past human activity and our interpretation of the data must always reflect this fact. 


\section{Palynological Analyses at Allt Dail an Dubh-asaidh}

\subsection{Introduction and Summary}

This section presents the results of pollen analysis of deep peat deposit at Allt Dail an Dubh-asaidh (NGR: NM 6714 9054) on the line of the re-aligned A830 road, between Arisaig and Mallaig.

The $6.67 \mathrm{~m}$ pollen core was analysed at a sample resolution of $4 \mathrm{~cm}$, giving a total of 160 samples. Radiocarbon dating of pollen zones throughout the core has indicated a date range from 8900 BP to the present day. Analysis of the pollen core at a resolution of approximately 50 years has illustrated a full Holocene sequence from open water prior to 8900 years BP.

This open water was colonized by willow carr, which after an open marsh phase with grasses, sedges and some fen species, was in turn colonized by alder carr at about 6000 years BP. Alder declined at about 4500 years BP to give way to a ling-dominated heath locally with birch-hazel-oak woodland in the wider area, with pine and elm. From this time, there is continuous evidence for low levels of disturbance relating to human activity. In addition, the extralocal and regional birch-hazel-oak woodland shows a gradual decline, with, at first, high frequencies of charcoal. With a local change to bog myrtle heath, charcoal frequencies decline; woodland pollen continues to decrease and ruderal pollen types, indicating disturbance, are consistently recorded. From $4500 \mathrm{BP}$, the sequence is interpreted as reflecting extensive grazing impacts which, particularly from about 2500 years BP, maintained a regionally open vegetation, with ruderal herbs and a continuing but gradual decline in woodland. This is proposed as an extensive, yet continuous, model of human use of the west coast of Scotland from late Neolithic times to the present day.

\subsection{Methodology}

An eigelkampf corer was used to take 3-cm diameter cores of sediments along two transects (see Illus 22) from across the Allt Dail an Dubh-asaidh basin at $70 \mathrm{~m}$ OD. In total 12 cores were sampled to assess basin profile (Illus 23, Illus 24). At the deepest point (marked 4* on Illus 22-24), a Russian corer was used to retrieve a 6 -cm diameter core for palaeoenvironmental analyses with a sediment block for the top $20 \mathrm{~cm}$. Stratigraphic descriptions of the sediments were carried out in the laboratory on cleaned sediment surfaces. Descriptions use the conventions of Troels Smith in Table 5 (Troels Smith 1955). Colours were described using international Munsell colour charts.
Pollen samples were prepared following standard procedures (Moore et al. 1991); Hydrofluoric acid (HF) was used to remove silica at the base of the profile. Marker spores were added to allow the calculation of pollen concentrations (Stockmarr 1972). Identifications were achieved using standard keys and a comprehensive reference collection; pollen taxonomy follows the Cataolgue of Pollen Types (Bennett 1995). English names for plants, pollen and spores are used where possible throughout the report, although the pollen diagrams use Latin names. Where possible, bog myrtle (Myrica gale) and hazel type (Corylus avellana type) pollen have been separated. However, identifications cannot be made consistently (Edwards 1981) and hence the bog myrtle curve in this diagram represents a minimum, while the hazel curve in Zone $1 \mathrm{~F}$ is likely to be enhanced through the inclusion of undifferentiated Myrica pollen. Counts to at least 300 land pollen grains were made to achieve statistically reliable counts, although at some levels this total was not achieved because of high accumulation rates, particularly in Zones 1A and 1C. Each grain was also assigned to one of five preservation classes (wellpreserved, corroded, degraded, crumpled and broken), according to the dominant state of preservation (cf Cushing 1967, Tipping 1987). Routine counts of microscopic charcoal were made and were calculated as concentrations. Pollen percentages were calculated on the basis of total land pollen (TLP). Other types were calculated as a percentage of TLP plus group.

The resolution adopted here at $4 \mathrm{~cm}$ gives an approximate resolution of 50 years, which in Zones $1 \mathrm{E}$ and $1 \mathrm{~F}$ where human activity is reflected in the vegetation and archaeological record represents approximately two generations in human terms.

\subsection{Radiocarbon dates}

Six pollen zones have been identified, primarily reflecting changes in vegetation within the basin from open water through marsh to alder carr and then heath. Five radiocarbon dates taken at the zone boundaries have demonstrated that a full Holocene sequence is present with no evidence for truncation or major hiatuses. Accumulation rates have varied between 0.5 and $1.0 \mathrm{~cm}$ per decade, giving a high temporal resolution (Table 5).

\subsection{Results}

Results are presented in a percentage pollen diagram (Illus 25), and the main pollen, fern and moss 
Table 5 Pollen zones with radiocarbon dates and accumulation rates

\begin{tabular}{llllll}
\hline $\begin{array}{l}\text { Pollen } \\
\text { zone }\end{array}$ & $\begin{array}{l}\text { Depth } \\
\text { (cm) }\end{array}$ & $\begin{array}{l}\text { Summary } \\
\text { description }\end{array}$ & $\begin{array}{l}\text { Radiocarbon } \\
\text { date (from base } \\
\text { of zone), BP }\end{array}$ & $\begin{array}{l}\text { Accumu- } \\
\text { lation rate } \\
\text { (cm/year) }\end{array}$ & $\begin{array}{l}\text { Sample } \\
\text { resolution } \\
\text { (years/4cm) }\end{array}$ \\
\hline 1F & $176-0$ & Sedge-ling heath with birch-hazel-0ak woodland & $2410 \pm 75$ & 0.07 & 63 \\
$1 \mathrm{E}$ & $368-176$ & Ling heath with birch-hazel-oak woodland & $4520 \pm 60$ & 0.09 & 44 \\
$1 \mathrm{D}$ & $480-368$ & $\begin{array}{l}\text { Alder carr with Birch-hazel-oak woodland and } \\
\text { elm and pine }\end{array}$ & $6070 \pm 65$ & 0.07 & 57 \\
1C & $544-480$ & $\begin{array}{l}\text { Open marsh with birch-hazel-oak woodland plus } \\
\text { pine and elm }\end{array}$ & $7245 \pm 65$ & 0.05 & 80 \\
1B & $640-544$ & $\begin{array}{l}\text { Willow carr with birch-hazel-oak woodland with } \\
\text { pine }\end{array}$ & $8900 \pm 100$ & 0.06 & 67 \\
$1 \mathrm{~A}$ & $667-640$ & Open water with willow carr & - & & - \\
\hline
\end{tabular}

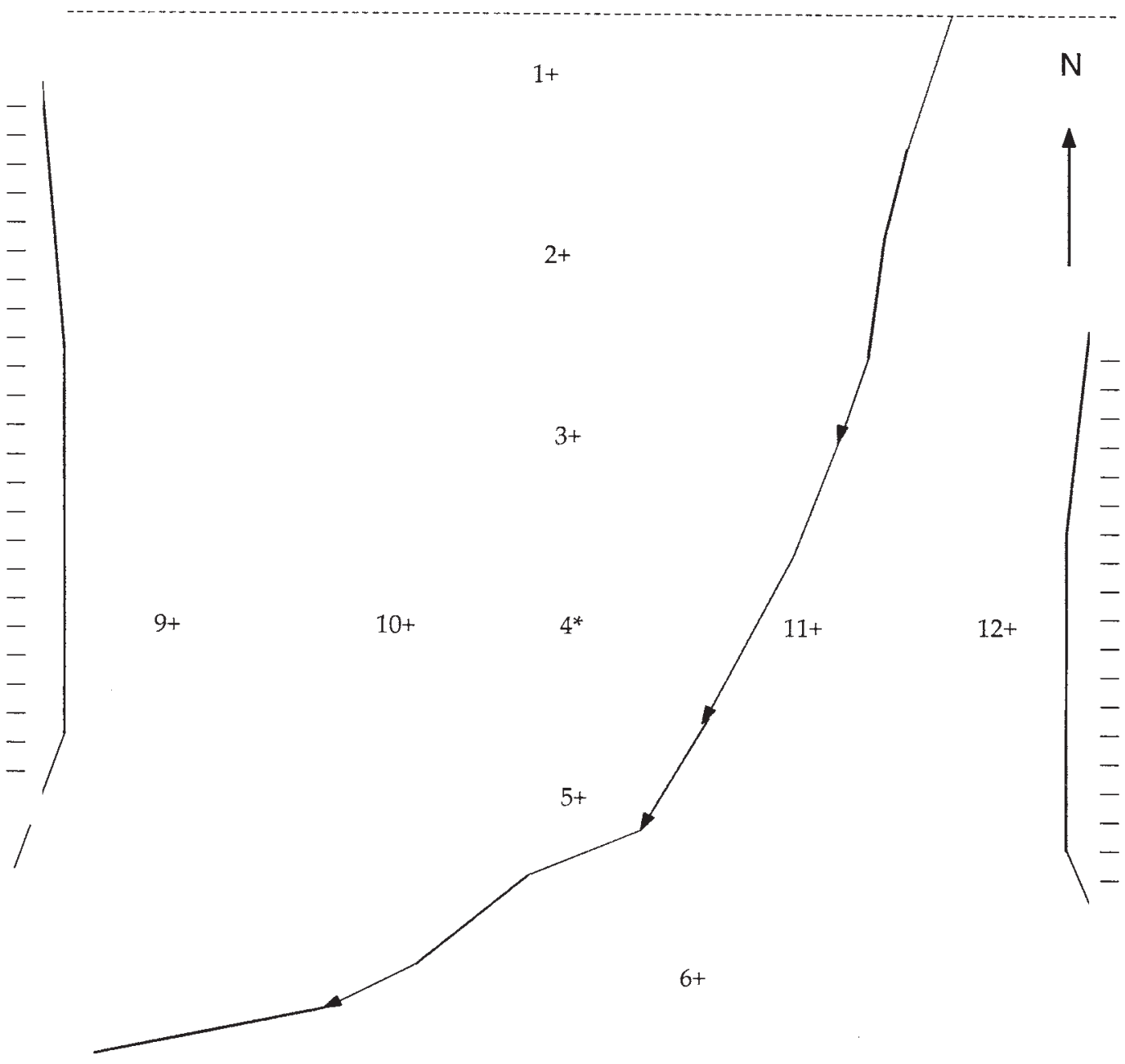

\section{KEY}

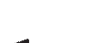

wall \& fence

$7+$

drainage ditch

$+$

stratigraphy point

$\mathrm{m}$

* $\quad$ pollen sampling point

higher ground

Illus 22 Sketch map showing core locations 


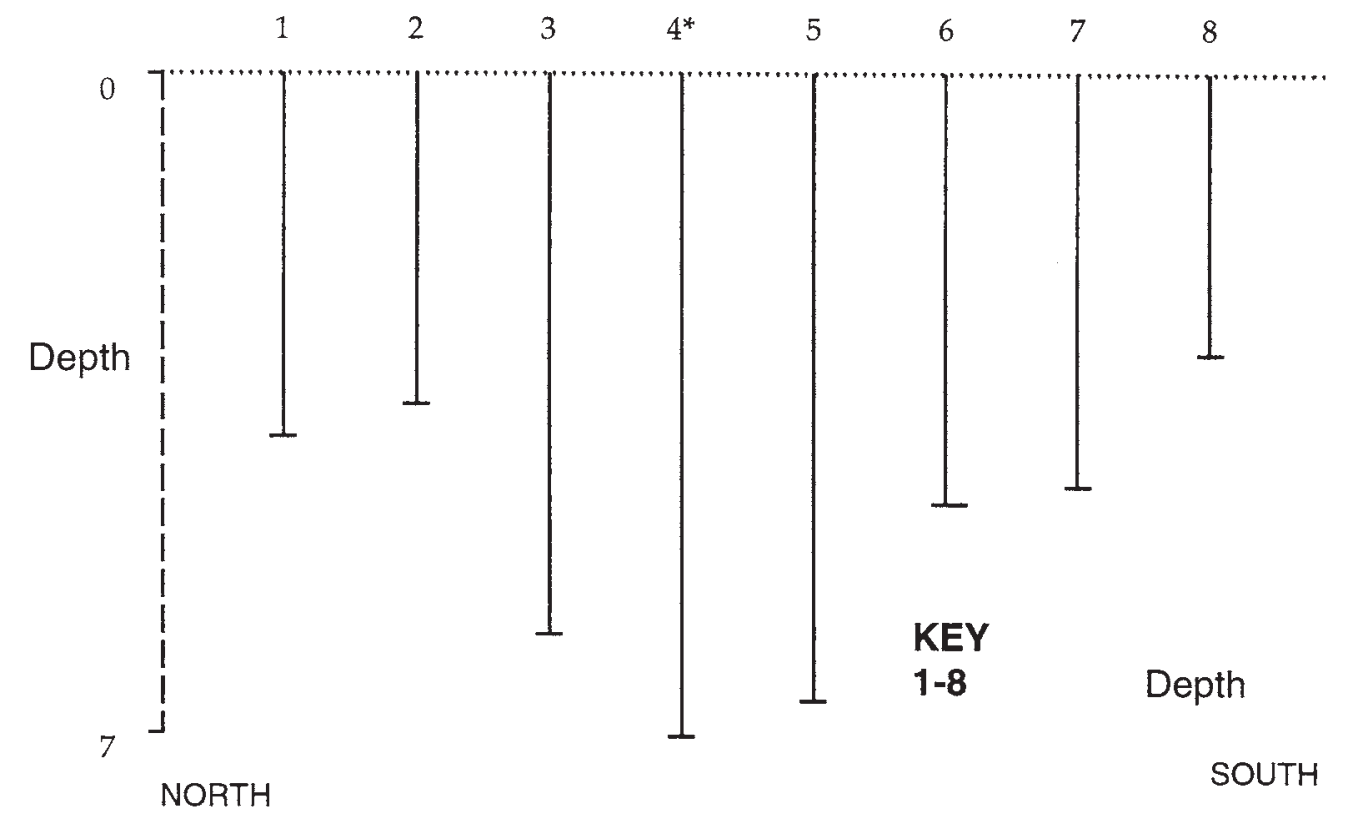

Illus 23 Long traverse basin depth profiles

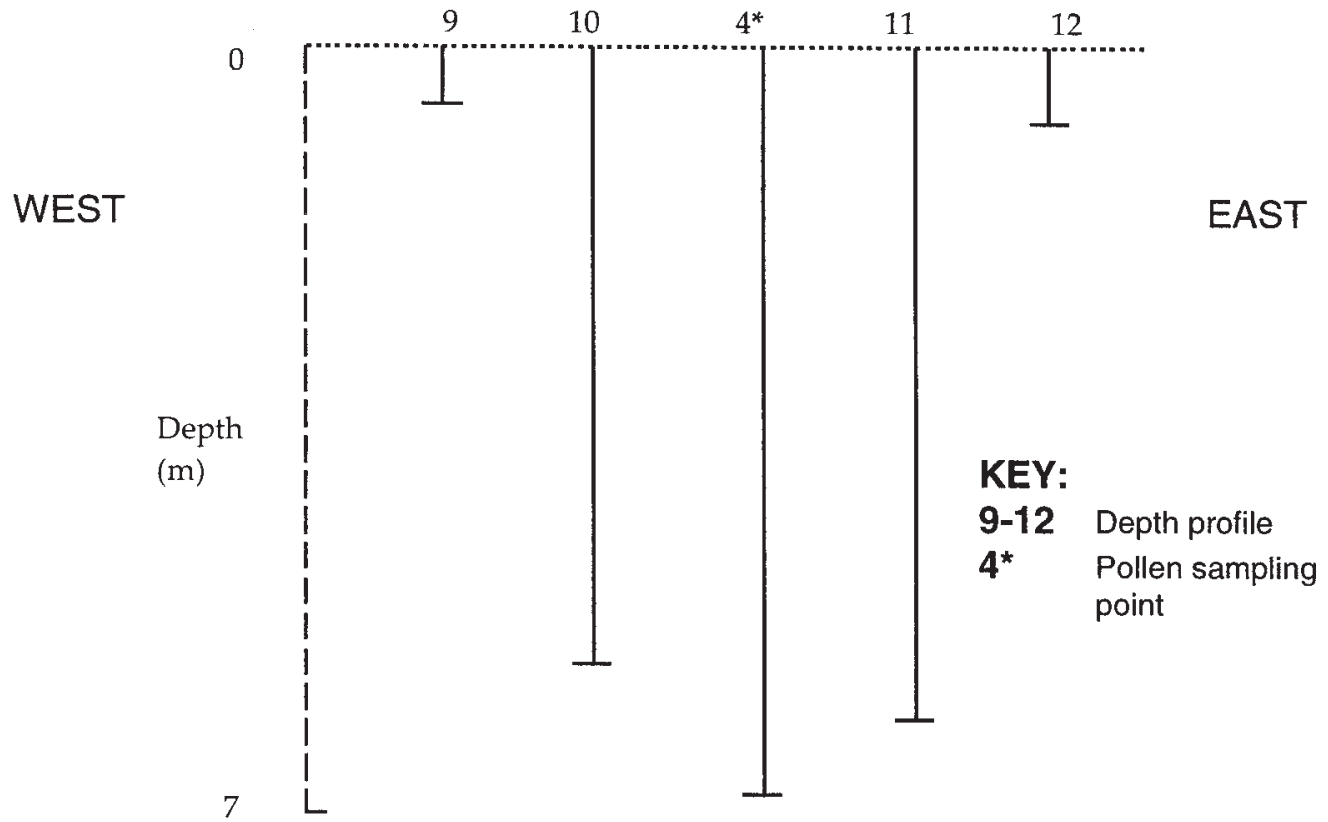

Illus 24 Short traverse basin profiles

spore curves are also presented as concentration curves in Illus 26. These additional curves remove the relative influence of the percentage data on curves and are useful in discerning actual changes in the pollen curves. Illus 27 shows pollen preservation data. Table 6 details the stratigraphic description of the pollen core.

The pollen diagram has been divided into six zones, based on dominant pollen types. Table 4 (see Section 7.1) summarizes the main characteristics of the pollen zones and indicates the dominant local (within the basin) and extra-local and regional vegetation (on the basin sides and further afield).

\subsection{Interpretation of pollen data}

\subsubsection{Zone 1A: Base to c $8900 \mathrm{BP}$}

In the clay and silty clays of this zone, pollen concentrations are low and there are some remnants of a late glacial-type flora, including crowberry (Empetrum nigrum) and meadow rue (Thalictrum), indicative of tundra conditions. However, locally, the pollen spectra are dominated by aquatic plants, growing in slow-flowing/non-moving water. This community was surrounded by willow carr with grasses and sedges. There is no archaeological 
Table 6 Stratigraphic descriptions of pollen core (Troels Smith notation)

\begin{tabular}{|c|c|c|c|}
\hline Depth (cm) & Munsell colour & Troels Smith description & Notes \\
\hline $0-67$ & $\begin{array}{l}\text { Very dark brown } \\
10 \text { YR } 2 / 2\end{array}$ & $\begin{array}{l}\text { Well-humified turfa peat } \\
\text { Th2 Sh2 }\end{array}$ & Grass and sedge roots \\
\hline $64-140$ & $\begin{array}{l}\text { Black } \\
\text { 5YR 2.5/1 }\end{array}$ & $\begin{array}{l}\text { Well-humified peat with herbacea } \\
\text { fragments } \\
\text { Sh3 Th1 Dh+ }\end{array}$ & Fragments of sedge \\
\hline $140-159$ & $\begin{array}{l}\text { Black } \\
\text { 10YR 2/2 }\end{array}$ & $\begin{array}{l}\text { Well-humified peat with herbacea and } \\
\text { woody fragments } \\
\text { Sh2 Th1 Dh1 Dl+ }\end{array}$ & $\begin{array}{l}\text { Grass and sedge fragments with } \\
\text { woody stems (ling)@ } 150\end{array}$ \\
\hline $159-227$ & $\begin{array}{l}\text { Very dark brown } \\
\text { 5YR } 2 / 2\end{array}$ & $\begin{array}{l}\text { Very well-humified peat with herbacea } \\
\text { and woody fragments } \\
\text { Sh4 Th+ Tl+ Dl+ }\end{array}$ & $\begin{array}{l}\text { Woody stems (ling)@ } 182 \& 194 \\
\text { Large wood piece@ } 209-210\end{array}$ \\
\hline $227-324$ & $\begin{array}{l}\text { Black } \\
\text { 5YR 2.5/1 }\end{array}$ & $\begin{array}{l}\text { Well-humified peat with herbacea and } \\
\text { woody fragments } \\
\text { Sh3 Th1 Tl+ Dg+ Dl+ }\end{array}$ & $\begin{array}{l}\text { Fragments of grass and sedge stems, } \\
\text { also ling }\end{array}$ \\
\hline $324-326$ & & $\begin{array}{l}\text { Well-humified detritus peat } \\
\text { Sh2 Dl2 }\end{array}$ & \\
\hline $326-338$ & $\begin{array}{l}\text { Black } \\
\text { 5YR 2.5/1 }\end{array}$ & $\begin{array}{l}\text { Well-humified peat with herbacea and } \\
\text { woody fragments } \\
\text { Sh3 Th1 Tl+ Dg+ Dl+ }\end{array}$ & $\begin{array}{l}\text { Fragments of grass and sedge stems, } \\
\text { also ling }\end{array}$ \\
\hline $338-404$ & $\begin{array}{l}\text { Black } \\
\text { 5YR 2.5/1 }\end{array}$ & $\begin{array}{l}\text { Very well-humified peat } \\
\text { Sh4 Th+ Dl+ }\end{array}$ & \\
\hline $404-408$ & $\begin{array}{l}\text { Black } \\
\text { 10YR 2/1 }\end{array}$ & $\begin{array}{l}\text { Well-humified peat with herbacea and } \\
\text { woody fragments } \\
\text { Sh2 Dg1 Dl1 Th+ Dh+ }\end{array}$ & Large wood pieces $($ diam $>2 \mathrm{~cm})$ \\
\hline $408-465$ & $\begin{array}{l}\text { Black } \\
\text { 5YR 2.5/1 }\end{array}$ & $\begin{array}{l}\text { Very well-humified peat } \\
\text { Sh4 Th+ Dl+ }\end{array}$ & Grass and sedge stem fragments \\
\hline $465-471$ & $\begin{array}{l}\text { Black } \\
\text { 10YR 2/1 }\end{array}$ & $\begin{array}{l}\text { Well-humified peat } \\
\text { Sh3 Th1 Dh+ }\end{array}$ & \\
\hline $471-651$ & $\begin{array}{l}\text { Black } \\
\text { 5YR 2.5/1 }\end{array}$ & $\begin{array}{l}\text { Well-humified peat with silt } \\
\text { Sh4 Th+ Tl+ Dh+ As+ }\end{array}$ & \\
\hline $651-657$ & $\begin{array}{l}\text { Dark grey } \\
10 \text { YR } 4 / 1\end{array}$ & $\begin{array}{l}\text { Clay with organic and silty elements } \\
\text { Ag3 Sh1 Th+ Dh+ As+ }\end{array}$ & Mica present \\
\hline $657-662$ & $\begin{array}{l}\text { Greyish-brown } \\
10 \text { YR } 5 / 2\end{array}$ & $\begin{array}{l}\text { Silty clay } \\
\text { As2 Ag2 } \mathrm{Sh}+\mathrm{Dh}+\end{array}$ & Mica present \\
\hline $662-667$ & $\begin{array}{l}\text { Very dark greyish-brown } \\
\text { 10YR } 3 / 2\end{array}$ & $\begin{array}{l}\text { ClayAg } \\
4 \mathrm{Sh}+\mathrm{Dh}+\end{array}$ & $\begin{array}{l}\text { Mica present. Occasional herbaceous } \\
\text { stem remains }\end{array}$ \\
\hline
\end{tabular}

evidence for any human activity at this time and the pollen spectra do not indicate any evidence of human activity.

\subsubsection{Zone 1B: c 8900-7245 BP}

Locally, willow carr dominates and has colonized the open water in Zone 1A. As a component of the local vegetation, willow (Salix) is a low pollen producer (Bradshaw 1981) and its local presence is only shown in the concentration curves. Birch (Betula) and hazel (Corylus type) were also present locally in the canopy. The understory was composed of sedges (Cyperaceae), grasses (Poaceae), ling (Calluna vulgaris), Sphagnum mosses with some fen types, including meadowsweet (Filipendula ulmaria). Sphagnum is likely to have been restricted to discrete pockets where ground conditions were more acidic. Otherwise the vegetation indicates a neutral to slightly base environment.
From $624 \mathrm{~cm}$, near the base of this zone, oak (Quercus) and elm (Ulmus) start to increase. Beyond the local carr, a mixed woodland with birch, hazel, elm, oak and pine (Pinus diploxlon type) occurred. The presence of elm, in particular, in the extra-local and regional woodland is shown in the pollen concentrations in Zone 1B.

There are some indications of very low levels of disturbance in the vegetation reflected by the occasional presence of ruderal herbs but it is difficult to relate these entirely to human activity. Such low levels of disturbance could equally be the result of natural disturbance in the birch-hazel woodland.

\subsubsection{Zone 1C: с 7245-6070 BP}

The pollen diagrams both show an open marsh with sedges and grasses and some fen herb species in Zone 1C. The increases in pine pollen and microscopic charcoal may reflect an increased recruitment area 


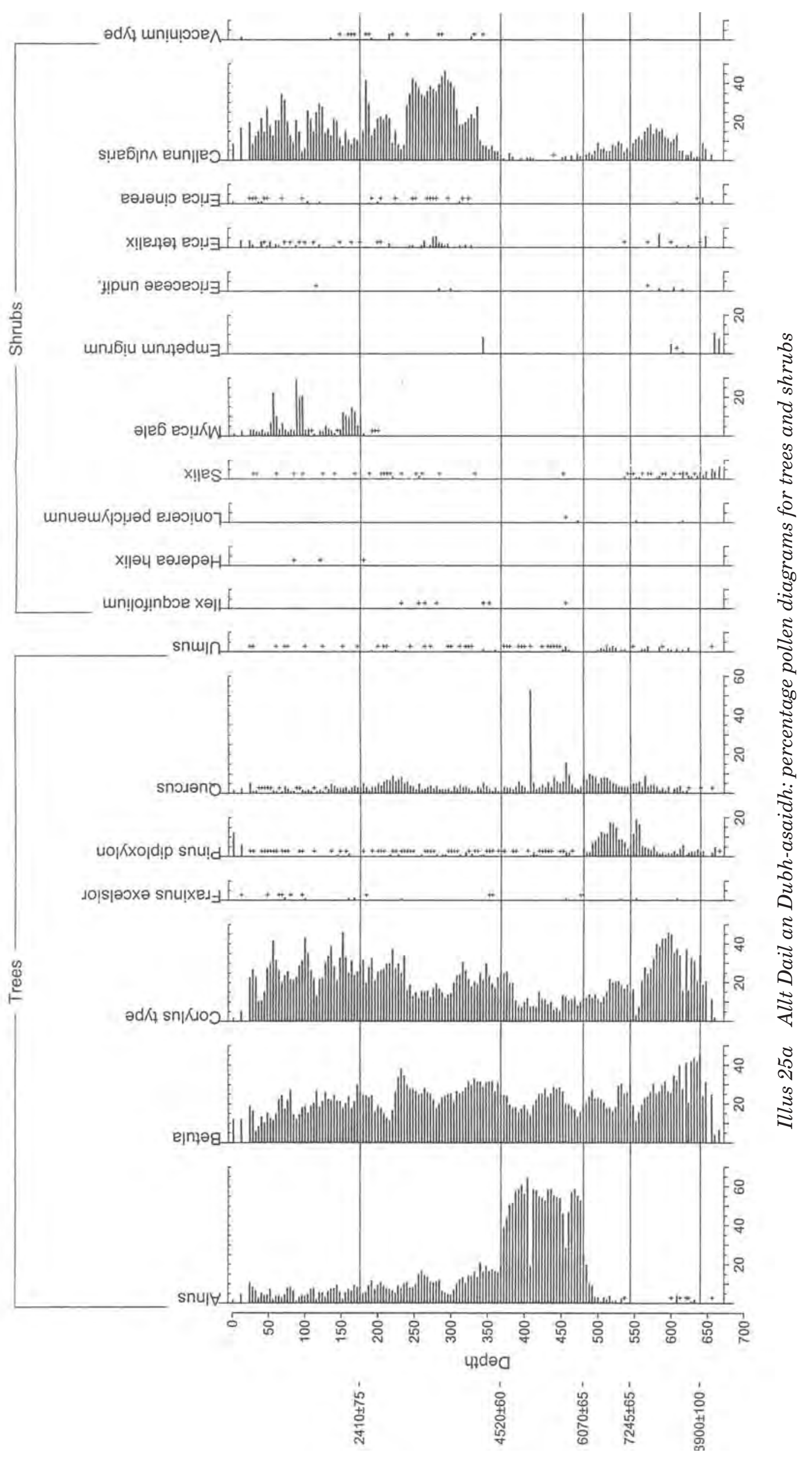




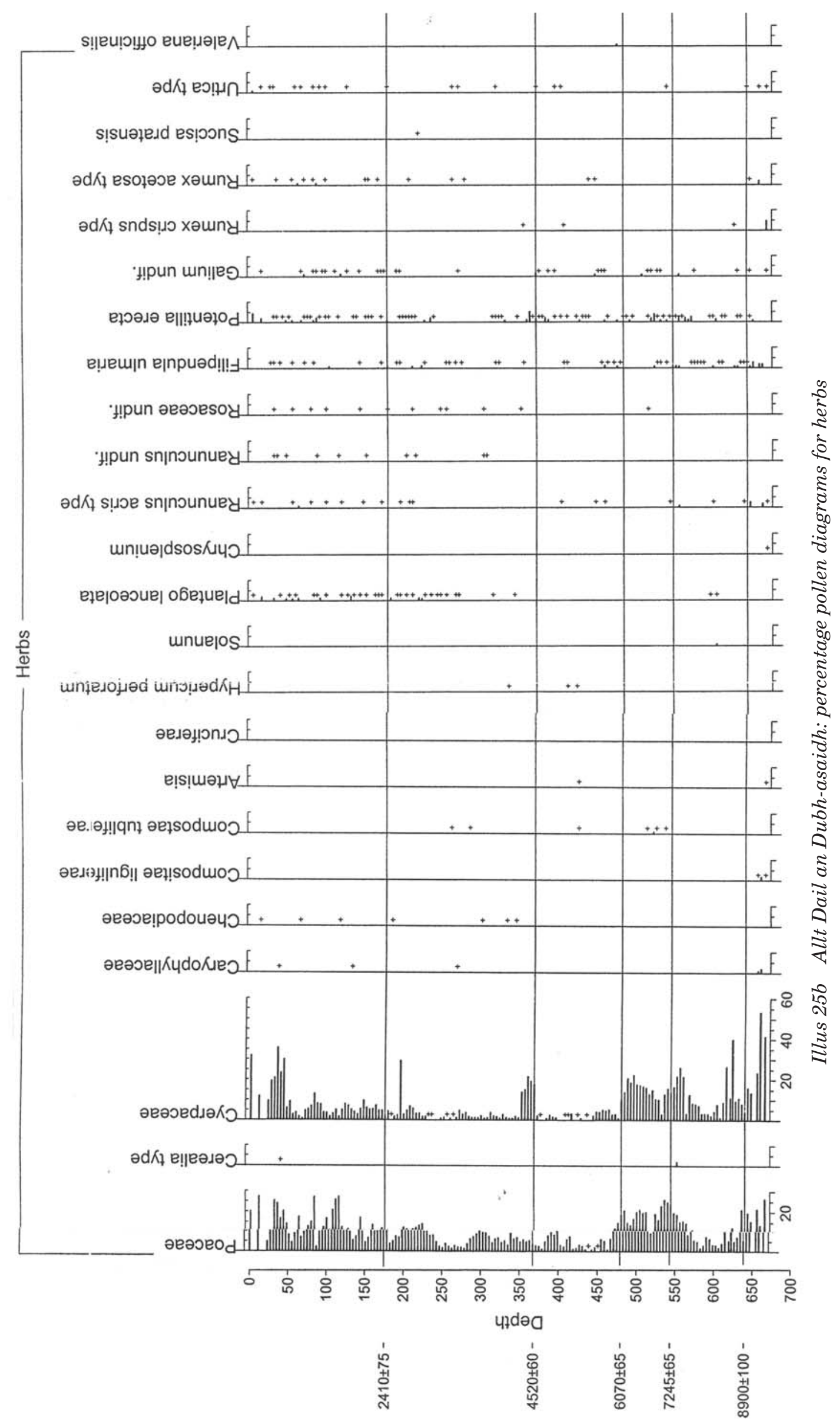




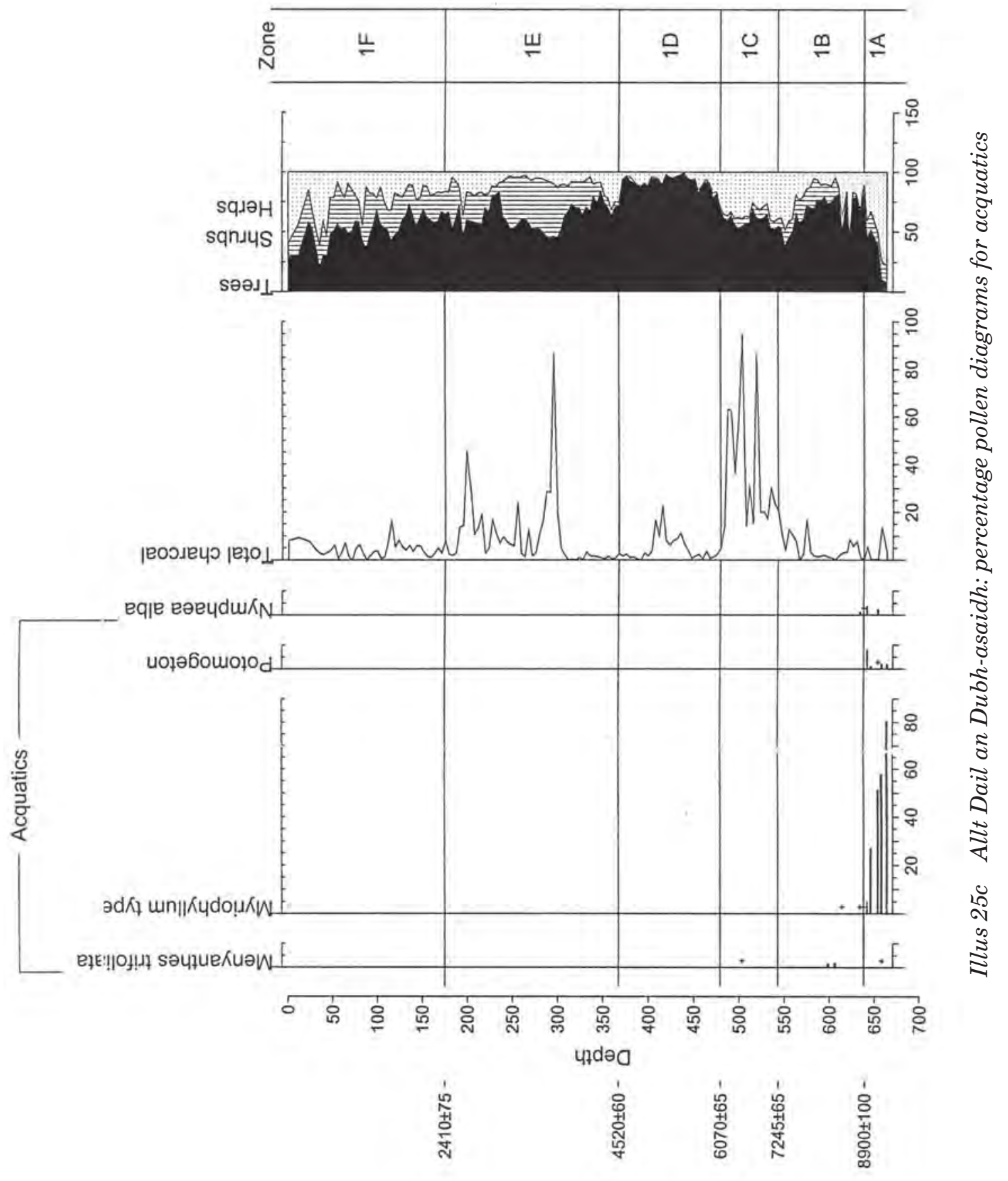




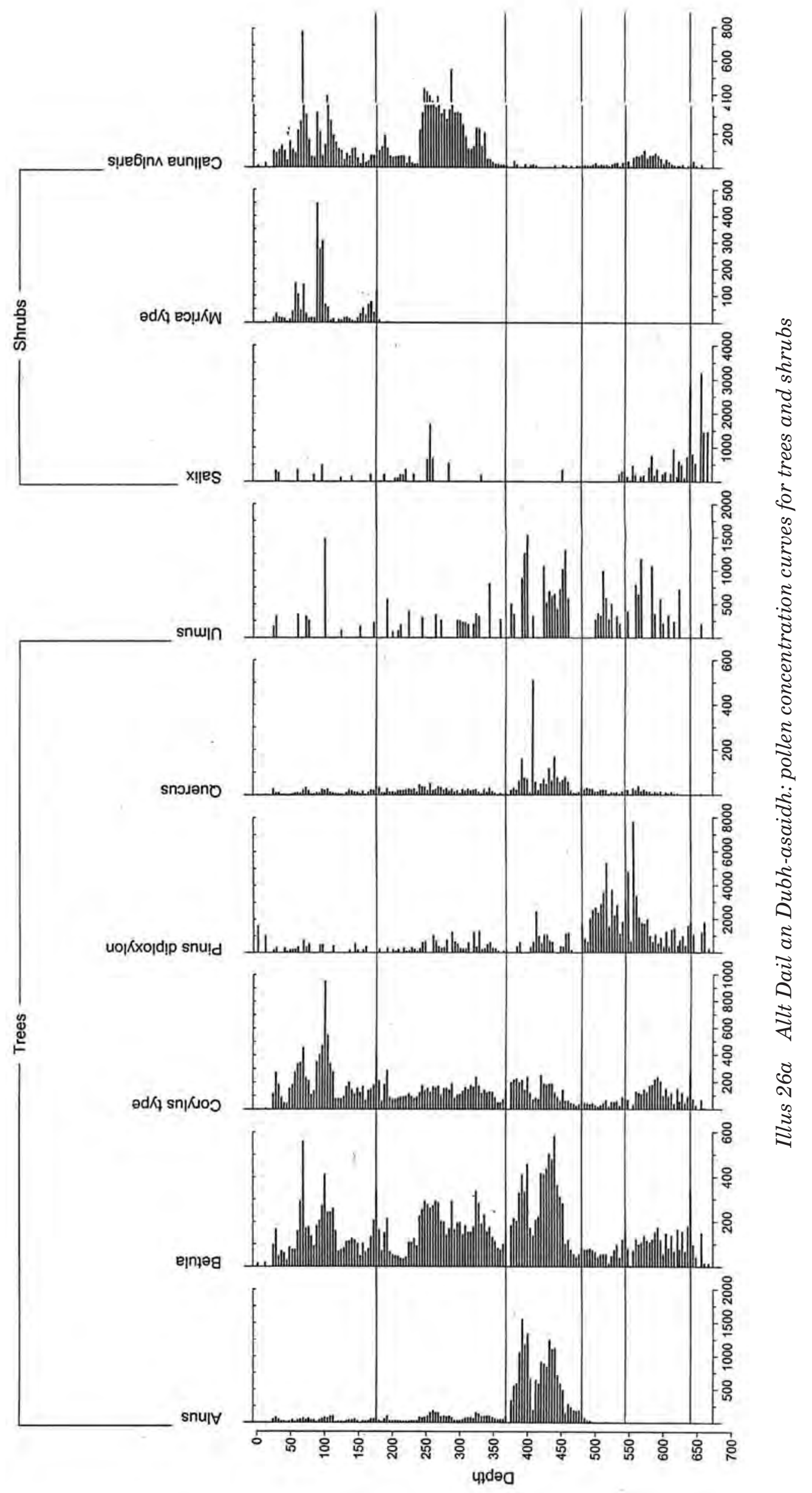




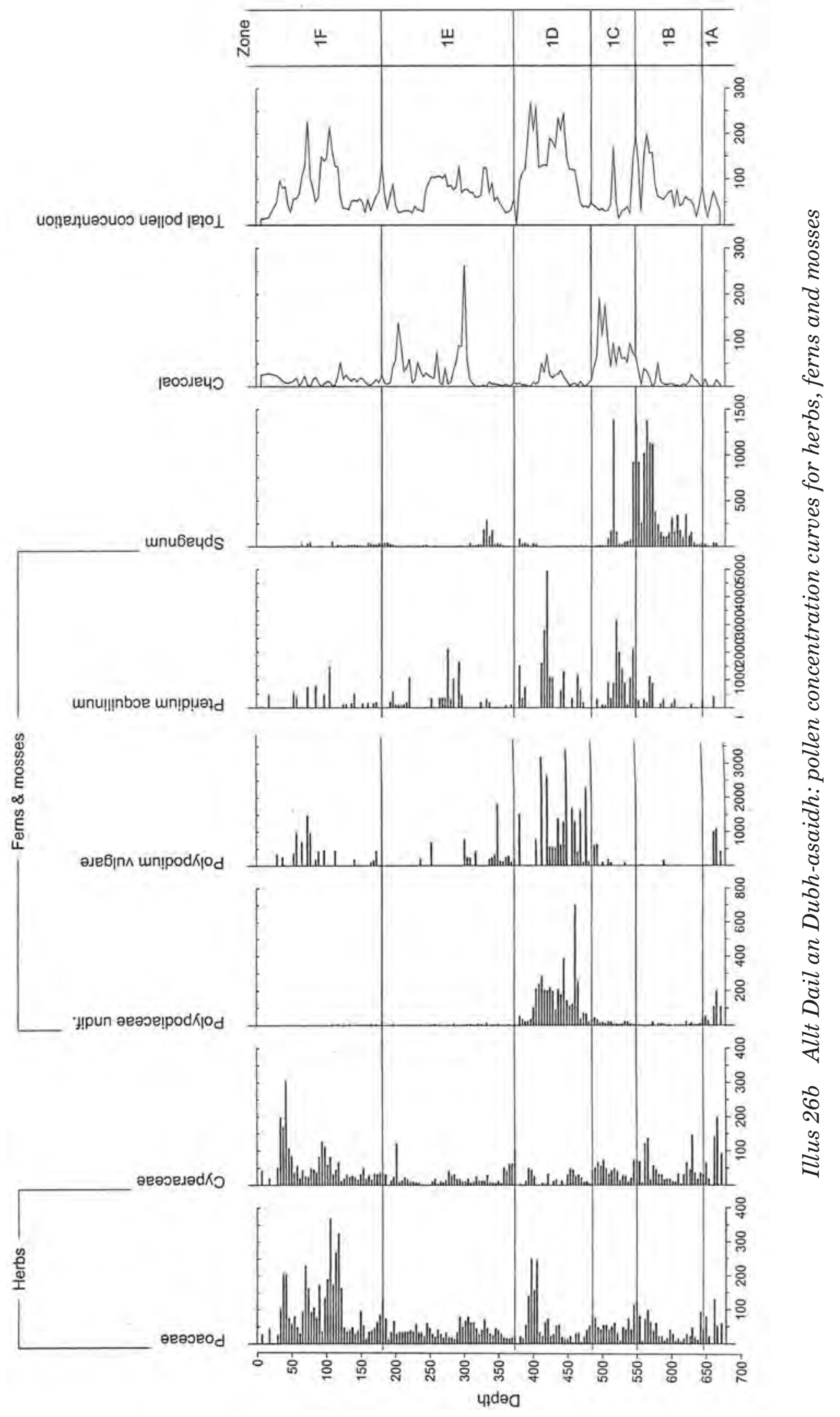




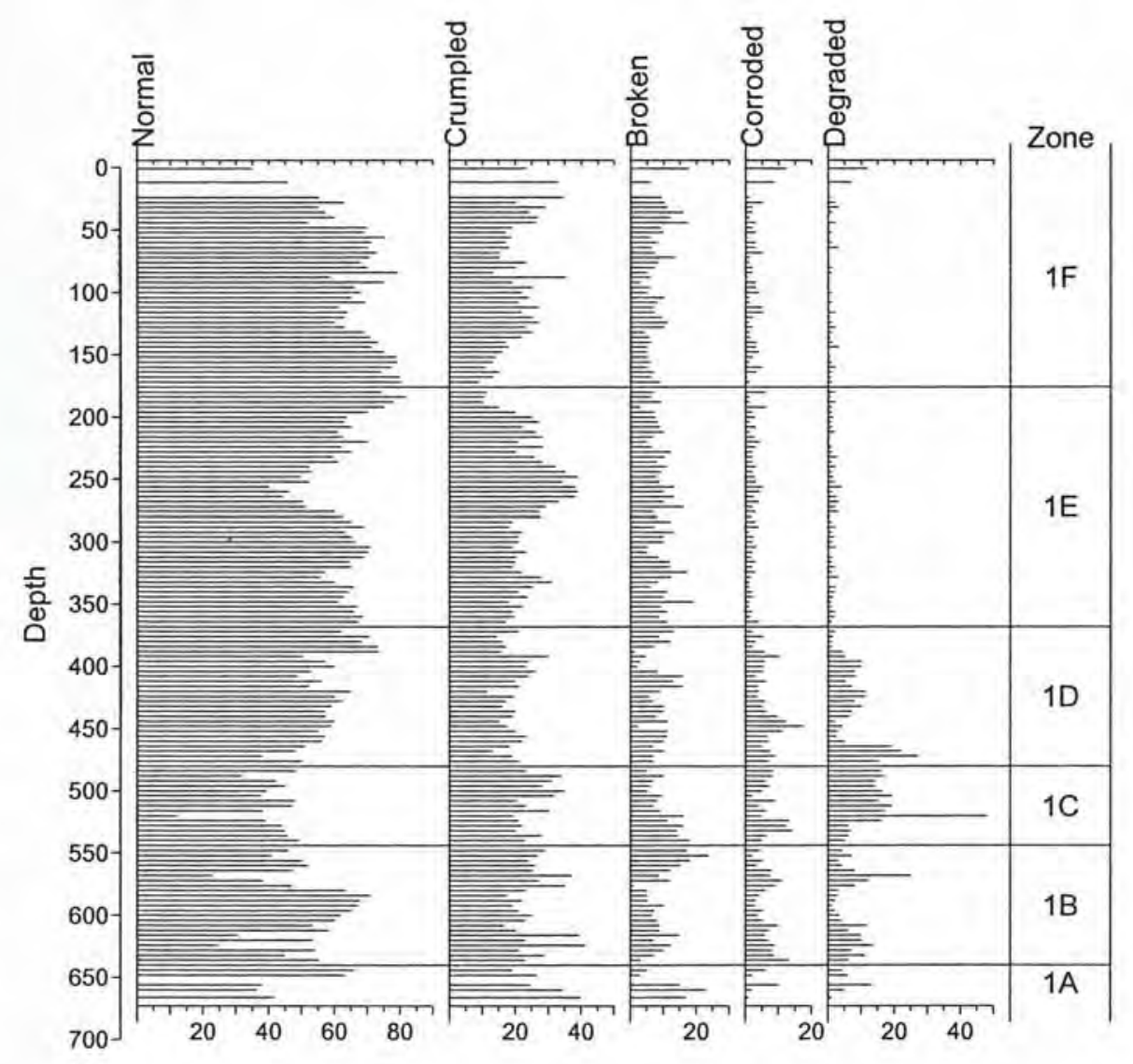

Illus 27 Allt Dail an Dubh-asaidh: pollen condition classes

resulting from the opening up of the willow carr. This opening of the canopy may also account for the increase in bracken spores, although bracken produces spores on an irregular basis and the apparent increase may have been caused by other factors (Page 1982). Pine, as a component of the extra-local and regional woodland, is unlikely to have increased in occurrence in Zone 1C. Pine is notoriously overrepresented in pollen diagrams, particularly those from open sites (Bennett 1984; Fossit 1994) and this probably accounts for the apparent increase in pine in this zone. Both pine and elm pollen concentrations remain approximately constant from Zone 1B, suggesting no real increase in trees in Zone 1C.

The extra-local and regional areas would have been characterized by woodland dominated by birch and hazel with oak, elm and pine. Concentrations of birch and hazel have declined in Zone $1 \mathrm{C}$, which may be reflecting some low levels of woodland use and clearance by human populations. Of the herb types recorded, there is little evidence for higher levels of disturbance in open areas.

The charcoal curve indicates sustained level of burning in the area throughout Zone $1 \mathrm{C}$, which could be reflecting some human activity in the wider area, although again the larger catchment area, resulting from the decrease in local tree canopy, is likely to be inflating charcoal concentrations.. This activity would be taking place in a late Mesolithic context and, given the very low levels of evidence in the pollen record, is likely to have been of low impact and dispersed across the wider pollen catchment.

The sediment accumulation rates are slow throughout Zone 1C (see Table 5) and this is reflected in the low pollen concentrations throughout this zone (Illus 26). This is also suggested by the increase in corroded pollen grains, which may also indicate fluctuating water tables (Illus 27). If this is the case, the higher concentrations of elm and pine pollen grains, which are both relatively robust pollen types, are also illustrating poorer preservation conditions as well as a wider catchment area.

It is likely that the vegetation of Zone $1 \mathrm{C}$ was subjected to low levels of disturbance, possibly with some influence from human activity. However, given the larger catchment of Zone $1 \mathrm{C}$, this activity could have taken place throughout the wider area at the low levels of impact recorded in the pollen record.

\subsubsection{Zone 1D: с 6070-4520 BP}

Zone 1D is dominated by the rise in alder (Alnus glutinosa) pollen, with ferns and herbs (Illus 25). The alder rise at other pollen sites in the Arisaig area is a clearly recognizable feature of pollen diagrams, although dates for its inception vary. The start of the alder rise at the end of Zone $1 \mathrm{C}$, dated here to about 
$6000 \mathrm{BP}$, is much earlier than the alder rise dated at Mointeach Mhór, slightly further south (Shennan et al. 1995). This is reflecting local conditions and may reflect the local topography slightly above the Mointeach Mhór; the latter would have been subject to the maximum Holocene sea-levels at this time. At Lochan Doilead, the alder rise has also been dated to c 6000 years BP (Williams 1977).

This alder carr will have developed locally, with a dense canopy and the herbs represented would have been elements of the understory. These included Ranunculus acris type, which includes meadow buttercup, medowsweet, bedstraws (Galium type) and some ferns including lady fern (Athyrium felixfemina) and broad buckler fern (Dryopteris dilatata). Extra-locally, woodland would have been characterized by birch, hazel and oak woodland with elm and pine. Zone 1D covers the early Neolithic period and, with the dense local alder carr, any human activity outside the woodland is difficult to see because the filtering effect of the alder carr is significant.

There is no evidence in this zone. For the ubiquitous decline in elm pollen at about 5100 BP across north-west Europe (Whittington \& Edwards 1997). The elm pollen concentrations in Zone 1D are consistently high and gradually decrease through Zone $1 \mathrm{E}$ along with other tree pollen. Low levels of woodland clearance dispersed throughout the area would be compatible with a gradual decrease in all woodland tree pollen, where any vector for elm decline, whether felling or dutch elm disease, probably the most likely causes (Rackham 1990), would be dispersed throughout a large area. The lack of a visible elm decline at about 5100 BP is likely to be reflecting low levels of human activity, in the form of felling and opening up the woodland and was dispersed widely enough across the area to prevent a marked decline in elm pollen.

\subsubsection{Zone 1E: с 4520-2410 вР}

The start of Zone $1 \mathrm{E}$ is defined by the decline in the alder pollen. This is replaced locally by ling with heather (Erica tetralix and E. cinerea) and grasses. The zone starts with a short transitory sedge phase. This mirrors the vegetation sequence illustrated further south at Mointeach Mhór (Shennan et al. 1995), following the decrease of alder, dated later at that site to $2565 \pm 45$ years BP. Again this later date reflects local site conditions at Mointeach Mhór. It is now widely accepted that the rise and fall of alder pollen in the early to mid-Holocene is driven by local topographic and environmental factors rather than a continuous spread from source areas (Whittington \& Edwards 1997).

Although there are only low levels of indicators for human activity throughout the diagram in Zone $1 \mathrm{E}$ there is a continuous evidence for ribwort plantain (Plantago lanceolata), which is associated with disturbed habitats (Godwin 1975; Grime et al. 1992). Other ruderal herbs recorded that reflect distur- bance include nettle and goosefoot. Their sustained curves indicate sustained levels of disturbance.

Zone $1 \mathrm{E}$ straddles the mid-Neolithic to the end of the Bronze Age. The locally open vegetation dominated by ling with grasses and heather reflects a wider pollen catchment area and indicators of low levels of human activity in the wider area are more evident. Zone $1 \mathrm{E}$ is also characterized by the start of a gradual decline in tree pollen, illustrated in the summary curves on Illus 25 . All the tree curves show progressive declines throughout Zone $1 \mathrm{E}$, reflecting steady continuous decrease in tree canopy. The slow decline of elm throughout Zone $1 \mathrm{E}$ is comparable to the decline in other tree pollen concentrations, which suggests low levels of woodland clearance in discrete areas, but not necessarily favouring elm, one of the theories for the widespread elm decline. Humans, as factors in woodland decline are implicated by the rise in ruderal herb pollen and charcoal, but the low levels of evidence reflects an extensive use of the area. This evidence for human activity in Bronze Age times is supported by archaeological evidence for Late Bronze Age sites in the Arisaig area.

The zone is also marked by microscopic charcoal throughout, which after the sharp increase halfway through the zone at $296 \mathrm{~cm}$, continues throughout the zone. Again this is likely to be reflecting human activity. Extra-locally the woodland remains characterized by birch and hazel, with lower levels of oak, elm and pine.

\subsubsection{Zone 1F: c 2410-present}

Zone $1 \mathrm{~F}$ is marked by the local change from a ling-dominated heath to one with increased grasses, sedges and bog myrtle (Myrica gale). Despite the fact that the curve for bog myrtle is a minimum, because of the difficulties in distinguishing consistently between pollen from hazel and bog myrtle (Edwards 1981), there is nonetheless a definite change in the pollen record from ling to a bog myrtle heath. This type of succession has been associated with changes in climate, burning or grazing (Rodwell 1991). Microscopic charcoal is present at low levels throughout the zone. So unless the trigger was the consistently higher charcoal levels throughout Zone $1 \mathrm{E}$, over a 2000 -year period, then burning is unlikely as a major cause. The date at the start of Zone $1 \mathrm{~F}$ (2410 BP) coincides with the end of the Bronze Age and a generally accepted change in climate to wetter conditions across Scotland (eg Dubois \& Ferguson 1985; Gear \& Huntley 1991). This could have triggered the change from woodland to heath with increased grasses, sedge and bog myrtle. The decline in woodland could also be related to increased grazing throughout Zone $1 \mathrm{~F}$, although this is difficult to distinguish directly in the pollen record (see below). It is more likely to be a combined change to a wetter climate alongside increased grazing regimens, reflected in the woodland decline but with low levels of burning. 
Around the local sedge and bog myrtle heath, birch and hazel woodland with oak is found. Although the concentrations of hazel and birch seem high for an apparently open environment, these values are likely to be reflecting the local woodland to the south and east. In addition, research by Bunting indicates that these levels of arboreal pollen are consistent with an open environment on the west coast of Scotland with woodland in local pockets (Bunting 2002). The increase in pine pollen towards the top of Zone $1 \mathrm{~F}$ (from $12 \mathrm{~cm}$ ) is likely to be reflecting modern plantations.

Throughout Zone $1 \mathrm{~F}$ there are clear indications of sustained disturbance in the vegetation, although again at consistently low levels. Curves for ruderal herbs, including ribwort plantain, nettle, sorrel and goosefoot are sustained throughout. The pollen catchment area is gradually widened throughout Zone $1 \mathrm{~F}$ because of the decline in woodland cover, although charcoal frequencies remain low, suggesting that burning was not a major activity. It is more likely that the sustained ruderal pollen curves and the gradual decline in tree pollen reflect increasing grazing levels throughout the region.

\subsection{Interpretation of charcoal data}

The charcoal curve in these diagrams (Illus 25, Illus 26) shows increased burning in Zones $1 \mathrm{C}$ and $1 \mathrm{E}$. From 7200 to 6000 BP in Zone 1C, this is likely to reflect an increased pollen catchment area, following the opening up of the willow carr characterizing Zone $1 \mathrm{~B}$. There is very little pollen evidence for human activity throughout Zone $1 \mathrm{C}$, which is consistent with the early dates, although the increased charcoal reflects a higher frequency of burning events than could be assumed to be natural.

In Zone $1 \mathrm{E}$, from 4500 to $2400 \mathrm{BP}$, burning frequencies increase, with a decline in tree pollen and indicators of disturbance in the form of ruderal herbs. The burning in this zone is likely to be a result of human activity, although again at low levels and dispersed throughout the area.

\subsection{Natural vegetation succession}

Natural processes of succession account for most of the local vegetation changes recorded at Allt Dail an Dubh-asaidh. The colonization of open water by willow carr would have occurred with sedimentation of the basin. Willow carr occupies generally neutral to basic conditions and the apparently odd inclusion of Sphagnum in this local community is likely to reflect pockets where slight acidification can occur, perhaps at the basin edge (cf Salix cinerea-Betula pubescens-Phragmites australis woodland, Rodwell 1991). However, the generally neutral to basic nature of the area is maintained and Sphagnum disappears with the development of an open marsh characterized by sedges and grasses. This open phase allowed the colonization of the local area by alder carr. Towards the end of this phase, acidification seems to occur as alder dies away and ling takes over the basin. The increase in bog myrtle in Zone $1 \mathrm{~F}$ is likely to relate to the continuing influence of water inflow, helping it compete with ling.

Changes in the extra-local and regional woodland are harder to interpret, although there are clearly fluctuations in canopy composition and extent. The changes from willow- to alder-dominated carr are likely to reflect natural successional changes, as above. In the wider landscape, the birch-hazel-oak woodland remains constant in Zone 1D, and its gradual decline starting in Zone $1 \mathrm{E}$ and continuing through Zone $1 \mathrm{~F}$ is likely to relate more to human activity and possibly woodland decline as a result of increased grazing.

\subsection{Human activity}

There has been little archaeological evidence recorded for human activity in the area around Allt Dail an Dubh-asaidh until the 19th and 20th centuries and there is similarly little evidence for human activity affecting the vegetation, until Zone $1 \mathrm{~F}$, after about 2400 years BP. Most of the main changes in vegetation at the pollen site can be accounted for through natural succession.

However, human activity reflected in the pollen record is at a consistently low level throughout the diagram from the Mesolithic period to the present day. Woodland cover at a local and extra-local and regional scale is maintained to the start of Zone $1 \mathrm{E}$ at about 4500 BP. From this time, woodland declines gradually and is likely to be reflecting human activity throughout the area at sites local to and further away from the pollen core site. This sustained human activity at low levels throughout the area is supported by the curves for ruderal pollen types like ribwort plantain, nettle and goosefoot.

In Zone $1 \mathrm{~F}$, while the decline in woodland pollen continues along with sustained curves for ruderal pollen types, charcoal frequencies decline. This suggests sustained but low levels of disturbance with human activity throughout the area but with less impact from burning activity. The sustained disturbance that causes continued declines in tree pollen and an increase in open vegetation is likely to be increased grazing.

\subsection{Conclusions}

The vegetation record at Allt Dail an Dubh-asaidh, from the detailed pollen record described here, indicates low levels of disturbance, related to human activity from about 4500 years BP onwards. Before this time, any human activity would have caused even lower levels of disturbance that, although possible to discern in the pollen diagram, are likely to 
have been masked by natural vegetation succession at the pollen site.

From 4500 BP, the pollen record includes low but continuous levels of human disturbance. This would be consistent with small discrete areas of human activity that were used in an extensive pattern, on a temporary basis. This small-scale activity, in the form of woodland clearance, with some burning, was not necessarily in the same location and it is more likely that the activity moved from one small area to another through time. This would produce the low but sustained levels of ruderal herb pollen along with a very gradual decline in tree pollen. It is also likely that grazing played an increasingly important role in the vegetation. Although there are very few direct indicators for grazing in the pollen record, the impact of increased grazing is reflected in the suppression of tree pollen production and the maintenance of open vegetation types, particularly through Zone 1F. From 2500 BP onwards, therefore, the vegetation was disturbed on a continuous basis, probably grazing. This could have been either through transhumance practice throughout the area or through maintained grazing at a network of small sites. 


\section{Acknowledgements}

Archaeological investigations of the A830 road realignment at Arisaig spanned several years and involved many individuals and organizations. The entire archaeological project was funded by the Scottish Executive Transport Group and managed on its behalf by Patrick Ashmore of Historic Scotland. Initial stages of the project were undertaken by the Centre for Field Archaeology, University of Edinburgh, and we are grateful to staff of CFA for the ready provision of information through the later stages of the fieldwork and preparation of this publication. Fieldwork was facilitated by the various contractors and project managers working on the road construction project and we particularly wish to acknowledge the assistance of Bob Spence (Highland Council, Resident Engineer), Mike Horton (Ritchies), David Stevenson and Billy Johnston (Barr Construction).
Analysis of the excavated material has benefited from the work of a number of specialist consultants and we are grateful for contributions from Adrian Cox (post-medieval artefacts), Caroline Wickham Jones (lithics) and Mhairi Hastie (plant remains). Julie Mitchell (University of Edinburgh) is thanked for undertaking the pollen preparations and Paula Milburn for help with pollen analysis. Jane Bunting, Althea Davies and Eileen Tisdall all contributed to discussions on interpretations of the pollen sequence and we are grateful to Ciara Clark for allowing us to refer to her unpublished pollen data from Polnish. The illustrations for this report were drawn by Laura Speed, Tom Small and Lisa Wilson of Headland Archaeology. 


\section{References}

Bennett, K 1984 'The post glacial history of Pinus sylvestris in the British Isles', Quat Sci Rev 3, 133-155.

Bennett, K 1995 Catalogue of Pollen Types: Mid and Late Quaternary Sediments. Cambridge.

Bradshaw, R 1981 'Modern pollen representation factors for woods in south-east England', Journal of Ecology 69, 45-70.

Branigan, K, Foster, P 1995 Barra: Archaeological Research on Ben Tangaval. SEARCH, Vol 1. Sheffield.

Bunting, M J 2002 'Detecting woodland remnants in cultural landscapes: modern pollen deposition around small woodlands in northwest Scotland', The Holocene 12, 291-301.

Clarke, C 2000 A830-Polnish Bridge to Loch nan Uamh Improvement: Palynological Analysis from a Peat Core Near Arnabol Burn. CFS report no 528. Edinburgh.

Cushing, E 1967 'Evidence for differential pollen preservation in late Quaternary sediments in Minnesota', Rev Palaeobotany Palynology 4, $87-101$.

Davies A L, Tipping, R 2005 'Sensing small-scale human activity in the palaeoecological record: fine spatial resolution pollen analyses from West Glen Affric, northern Scotland', The Holocene 14.

Dubois, A D, Ferguson, D K 1985 'The climatic history of pine in the Cairngorms, based on radiocarbon dates and stable isotope analysis, with an account of the events leading up to its colonization', Rev Palaeobotany Palynology 46, $55-80$.

Edwards, K 1981 'The separation of Corylus and Myrica pollen in modern and fossil samples', Pollen et Spores 23, 205-218.

Fossitt, J 1994 'Modern pollen rain in the northwest of the British Isles', The Holocene 4, 365-376.

Gear, A, Huntley, B 1991 'Rapid changes in the range limits of Scots pine 4000 years ago', Science 251, 544-547.

Grime, J P, Hodgson, J G, Hunt, R 1992 The Abridged Comparative Plant Ecology. London.

Godwin, H 1975 The History of the British Flora. Cambridge.

Lynch, F, Ritchie J N G 1977 'Kerb-cairns', Proc Soc Antiq Scot (1974-75) 106, 30-33.

Moore, PD, Webb JA, Collinson, M 1991 Pollen Analysis, 2nd Edn. London.
Page, C N 1982 The Ferns of Britain and Ireland. Cambridge.

Rackham, O 1990 Trees and Woodland in the British Landscape. Phoenix.

Rees, A 1996 'Polnish chapel to Loch Nan Uamh viaduct', Disc Excav Scot 1996, 58.

Ritchie, A, Ritchie, G, Whittington G, Soulsby, J 1974 'A prehistoric field-boundary from the Black Crofts, North Connel, Argyll', Glasgow Archaeol J 3, 66-70.

Rixon, D 2002 Arisaig and Morar: A History. East Linton.

Rodwell, J 1991a British Plant Communities: Vol 1. Woodlands and Scrub. Cambridge.

Rodwell, J 1991b British Plant Communities, Vol 2. Mires and Heaths. Cambridge.

Shennan, I, Innes, J, Long, A, Zong, Y 1994 'Late Devensian and Holocene relative sea-level changes at Loch nan Eala, near Arisaig, northwest Scotland', J Quat Sci 9, 261-283.

Shennan, I, Innes, J, Long, A, Zong, Y 1995 'Late Devensian and Holocene relative sea-level changes in northwestern Scotland: new data to test existing models', Quat Intl 26, 97-123.

Shennan, I, Peltier, W R, Drummond, R, Horton B P 2002 'Global to local scale parameters determining relative sea level; changes and the post-glacial isostatic adjustment of Great Britain', Quat Sci Rev 21, 397-408.

Stockmarr, J 1972 'Tablets with spores used in absolute pollen analysis', Pollen et Spores 13, 615-621.

Tipping, R 1987 'The origins of corroded pollen grains at five early post-glacial pollen sites in western Scotland', Rev Palaeobotany Palynology 53, 151-161.

Troels Smith, J 1955 'Characterisation of unconsolidated sediments', Danmarks Geologiske Undersolgelse series IV 3, 38-73.

Whittington, G, Edwards, K 1997 'Vegetation change' in Edwards, K, Ralston, I (eds) Scotland: Environment \& Archaeology, 8000 BC $-A D$ 1000. London.

Wickham-Jones, C 1990 Rhum: Mesolithic and Later Sites at Kinloch. Excavations 1984-86. Society of Antiquaries of Scotland Monograph Series Number 7. Edinburgh.

Williams, W 1977 The Flandrian Vegetational History of the Isle of Skye and the Morar Peninsula. Unpublished $\mathrm{PhD}$ thesis, University of Cambridge. 